Faculty of Science

Faculty Publications

Apatite Trace Element Compositions: A Robust New Tool for Mineral Exploration

Mao Mao, Alexei S. Rukhlov, Stephen M. Rowins, J ody Spence, Laurence A. Coogan 2016

(c) 2016 Society of Economic Geologists.

This is an Open Access article distributed under the terms of the Creative Commons Attribution License (http://creativecommons.org/licenses/by/3.0), which permits unrestricted use, distribution and reproduction in any medium provided that the original work is properly attributed.

This article was originally published at:

https://doi.org/10.2113/econgeo.111.5.1187

Citation for this paper:

Mao, M., Rukhlov, A.S., Rowins, S.M., Spence, J. \& Coogan, L.A. (2016). C Apatite Trace Element Compositions: A Robust New Tool for Mineral Exploration. Economic Geology, 111(5), 1187-1222. https://doi.org/10.2113/econgeo.111.5.1187 


\title{
Apatite Trace Element Compositions: A Robust New Tool for Mineral Exploration*
}

\author{
Mao Mao, ${ }^{1}$ Alexei S. Rukhlov, ${ }^{2,+}$ Stephen M. Rowins, ${ }^{1,2}$ Jody Spence, ${ }^{1}$ and Laurence A. Coogan ${ }^{1}$ \\ ${ }^{1}$ School of Earth and Ocean Sciences, University of Victoria, 3800 Finnerty Road, Victoria, British Columbia, Canada V8P 5 C2 \\ ${ }^{2}$ British Columbia Geological Survey, Ministry of Energy and Mines, 1810 Blanshard Street, Victoria, British Columbia, Canada V8W 9 N3
}

\begin{abstract}
Apatites from the major types of mainly magmatic-hydrothermal mineral deposits (30 localities, mostly in British Columbia, Canada) together with apatites from carbonatites (29 intrusive complexes) and unmineralized rocks (11 localities) have been analyzed by electron microprobe and laser ablation-inductively coupled plasma mass spectrometry. Discriminant analysis using $\mathrm{Mg}, \mathrm{V}, \mathrm{Mn}, \mathrm{Sr}, \mathrm{Y}, \mathrm{La}, \mathrm{Ce}, \mathrm{Eu}, \mathrm{Dy}, \mathrm{Yb}, \mathrm{Pb}$, Th, and U reveals that apatites from mineral deposits can be distinguished from apatites in carbonatites and unmineralized rocks. Apatites from mineral deposits are characterized by higher Ca and correspondingly lower total contents of trace elements that partition onto the Ca sites (rare earth elements (REEs), Y, Mn, Sr, Pb, Th, and U) than apatites from unmineralized rocks and carbonatites. Apatites from the different deposit types also have distinct trace element compositions that are readily discriminated by the discriminant functions. Apatites from worldwide carbonatites have the most fractionated REE distributions with light REE enrichment $\left(\mathrm{Ce} / \mathrm{Yb}_{\mathrm{CN}}=35-872\right)$, high V (1.6-1,466 ppm), Sr (1,840-22,498 ppm), Ba (1.8-275 ppm), and Nb (0.4-19 ppm) contents, the lowest $\mathrm{W}$ contents $(0.05-0.55 \mathrm{ppm})$, and no significant $\mathrm{Eu}$ anomalies $\left(\mathrm{Eu} / \mathrm{Eu}^{*}=0.9-1.2\right)$. Apatites from alkalic porphyry $\mathrm{Cu}-\mathrm{Au}$ deposits in the North American Cordillera possess high V contents (2.5-337 ppm), whereas apatites from calc-alkaline porphyry $\mathrm{Cu}-\mathrm{Au}$ and $\mathrm{Cu}-\mathrm{Mo}$ deposits have high $\mathrm{Mn}$ contents (334-10,934 ppm) and typically large negative Eu anomalies $\left(\mathrm{Eu} / \mathrm{Eu}^{*}=0.2-1.1\right)$. Apatites from iron oxide $\mathrm{Cu}-\mathrm{Au}$ (IOCG) and related Kiruna-type iron oxide-apatite (IOA) deposits in Canada, China, and Mexico typically have large negative Eu anomalies $\left(\mathrm{Eu} / \mathrm{Eu}^{* *}=0.2-1.5\right)$ and low Mn contents (40-5,753 ppm). Apatites from orogenic Ni-Cu, porphyryrelated $\mathrm{Cu}-\mathrm{Au}$ breccia, Au-Co skarn, $\mathrm{Pb}-\mathrm{Zn}$ skarn, and $\mathrm{Cu}$ skarn deposits have relatively low abundances of impurity cations. This study demonstrates that detrital apatite grains collected during regional geochemical surveys are effective in identifying specific types of buried mineral deposits in glaciated terranes.
\end{abstract}

\section{Introduction}

Regional geochemical surveys that collect heavy or resistant indicator minerals (RIMs) in drift or drainage samples have proven successful in diamond exploration. They also have potential application to a wide range of other commodities (e.g., Griffin and Ryan, 1995; Averill, 2001; Belousova et al., 2002). Exploration tools such as this are valuable in regions where bedrock exposure is limited. For example, exploration for porphyry $\mathrm{Cu} \pm \mathrm{Mo} \pm \mathrm{Au}$ deposits in the highly prospective Late Triassic-Early Jurassic Quesnel and Stikine magmatic arc terranes of south-central British Columbia is challenging due to extensive cover by glacial sediments (Ward et al., 2009). Bouzari et al. (2011) have undertaken preliminary studies of RIMs associated with porphyry $\mathrm{Cu} \pm \mathrm{Mo} \pm \mathrm{Au}$ deposits and proposed that apatite, rutile, titanite, and magnetite are potential porphyry indicator minerals. An ideal indicator mineral should meet the following prerequisites: (1) widespread occurrence in rocks related to or within the deposit, (2) chemical composition sensitive to the crystallization environment, (3) resistance to physical and chemical weathering, and (4) easily identified and separated from its host rock or sediment. In consideration of these criteria, apatite, $\mathrm{Ca}_{5}\left(\mathrm{PO}_{4}\right)_{3}(\mathrm{~F}, \mathrm{OH}, \mathrm{Cl})$, qualifies as a good RIM candidate.

\footnotetext{
+ Corresponding author: e-mail address, alexei.rukhlov@gov.bc.ca

"A digital supplement to this paper is available at http://economicgeology. org/ and at http://econgeol.geoscienceworld.org/. It contains Appendices 1 and 2, Appendix Tables 1-6, Appendix Figures 1-4, and Supplementary movie files 1 and 2 .
}

Apatite is a widespread accessory phosphate mineral that occurs in many rocks and is relatively resistant to weathering (Bouzari et al., 2011). In general, felsic rocks such as granites, granodiorites, and rhyolites contain $\sim 0.01$ to 0.5 wt $\% \mathrm{P}_{2} \mathrm{O}_{5}$, mainly within apatite (Sha and Chappell, 1999; Belousova et al., 2001; Cao et al., 2012). Intermediate and mafic rocks have similar to slightly higher $\mathrm{P}_{2} \mathrm{O}_{5}$ contents, typically ranging from $\sim 0.1$ to 1 wt \% (Belousova et al., 2001; Campos et al., 2002; Wang et al., 2003; Mukhopadhyay et al., 2011). Carbonatites are much more enriched in phosphorous and can contain up to 7.7 wt \% $\mathrm{P}_{2} \mathrm{O}_{5}$ (Hogarth et al., 1985; Bühn et al., 2001).

The crystal structure and chemistry of apatite results in relatively high mineral-melt and mineral-fluid partition coefficients for many trace elements (Hughes and Rakovan, 2002; Pan and Fleet, 2002; Prowatke and Klemme, 2006). Calcium, a large cation, has two structural sites in apatite $\mathrm{Cal}$ and $\mathrm{Ca} 2$ ), which are capable of accommodating high concentrations of many trace elements, including $\mathrm{Na}, \mathrm{Mg}, \mathrm{Mn}$, $\mathrm{Fe}, \mathrm{Sr}, \mathrm{Y}, \mathrm{Ba}$, lanthanides (hereafter referred to as REE), $\mathrm{Pb}$, Th, and U. The abundance of some "trace" elements such as $\mathrm{Sr}$ and $\mathrm{Mn}$ can be up to 8.96 and $7.59 \mathrm{wt} \%$, respectively, in natural apatite (Rakovan and Hughes, 2000; Hughes et al., 2004). The apatite structure also allows anion groups such as $\mathrm{VO}_{4}^{3-}, \mathrm{AsO}_{4}^{3-}, \mathrm{SiO}_{4}^{4-}$ and $\mathrm{SO}_{4}^{2-}$ to replace $\mathrm{PO}_{4}^{3-}$ with or without a charge compensator (Pan and Fleet, 2002). The abundances of these chemical impurities in apatite can be affected by many factors. For example, previous studies (Watson and Green, 1981; Fleet and Pan, 1997; Prowatke and Klemme, 2006) have shown that the mineral-melt partition coefficients 
of $\mathrm{REE}$ in apatite increases with increasing melt $\mathrm{SiO}_{2}$ content and decreases with increasing temperature. Miles et al. (2014) observed that $\mathrm{Mn}^{2+}$ substitutes into apatite more readily than $\mathrm{Mn}^{3+}$ and concluded that redox conditions have more influence on the partitioning of $\mathrm{Mn}$ into apatite than does temperature. Based on these observations, it is apparent that the trace element composition of apatite is sensitive to the environment in which it forms. Importantly, the low solubility of $\mathrm{P}_{2} \mathrm{O}_{5}$ in silicate melts (Watson, 1980; Nash, 1984) commonly results in early apatite crystallization that may continue until late-stage fluid saturation and accompanying metallic mineralization.

Previous studies have used apatite as a petrogenetic indicator, an oxygen fugacity $\left(f_{\mathrm{O}_{2}}\right)$ proxy, and as an indicator for mineral exploration (Sha and Chappell, 1999; Piccoli and Candela, 2002; Cao et al., 2012; Miles et al., 2014). Sha and Chappell (1999) and Belousova et al. (2001, 2002) have systemically investigated apatite in granitoids and suggested that these rock types could be identified based on the contents of specific trace elements (e.g., Mn, Fe, Sr, Y, and REE) in apatite. For example, Sha and Chappell (1999) recognized that depletion in LREE and Th in apatite from S-type and felsic I-type granitoids was due to the occurrence of monazite, whereas its absence in mafic I-type granitoids produced an enrichment of these elements in apatite. Belousova et al. (2002) documented very high $(\mathrm{Ce} / \mathrm{Yb})_{\mathrm{CN}}$ in apatites from carbonatites and mantle-derived lherzolites. Little research, however, has focused on possible correlations between trace elements in apatites and different types of mineral deposits. Studies of Cao et al. (2012) and Bouzari et al. (2011) on both magmatic and hydrothermal apatites from porphyry $\mathrm{Cu} \pm \mathrm{Mo}$ $\pm \mathrm{Au}$ deposits suggested that trace elements in apatites could be used in exploration for these deposits. Therefore, developing a robust trace element classification for apatite could provide a useful mineral exploration tool and an efficient way to discriminate between deposit types.

This study evaluates apatite trace element compositions to do the following: (1) discriminate between apatites formed in association with mineral deposits from those formed in unmineralized rocks; and (2) discriminate apatites from the different types of mineral deposits. To achieve these objectives, we have analyzed more than 600 apatite grains from porphyry $\mathrm{Cu} \pm \mathrm{Mo} \pm \mathrm{Au}$ deposits, epithermal $\mathrm{Au}-\mathrm{Ag}$ veins, iron oxide $\mathrm{Cu}-\mathrm{Au}$ (IOCG) breccia and related Kirunatype iron oxide-apatite (IOA) deposits, orogenic Au veins, polymetallic skarns, orogenic Ni-Cu deposits, and carbonatite $\mathrm{REE} \pm \mathrm{Nb} \pm \mathrm{Ta}$ deposits, as well as approximately 300 apatite grains from unmineralized rocks, including clinopyroxenites, gabbros, diorites, granodiorites, monzonites, and syenites. Discrimination diagrams are used to subdivide the apatites by origin and the results indicate that apatite is a robust indicator mineral for exploration.

\section{Structural chemistry of trace elements in natural apatites}

Apatite, $\mathrm{Ca}_{5}\left(\mathrm{PO}_{4}\right)_{3}(\mathrm{~F}, \mathrm{OH}, \mathrm{Cl})$, consists of hexagonal close packing tetrahedral $\mathrm{PO}_{4}^{3-}$ groups, which form two types of structural channels parallel to the hexagonal axis. Forty percent of the Ca atoms occupy the smaller channels with ninefold coordination ( $\mathrm{Cal}$ site), whereas the $\mathrm{F}(\mathrm{OH}, \mathrm{Cl})$ occupies the center of the larger channel. The other $60 \%$ of the $\mathrm{Ca}$ surrounds the $\mathrm{F}(\mathrm{OH}, \mathrm{Cl})$, forming seven-fold coordination (Ca2 site) within the larger channel. This structure is capable of tolerating relatively large structural distortions, allowing for diverse substitutions (Hughes and Rakovan, 2002; Pan and Fleet, 2002). The radius of $\mathrm{Ca}^{2+}$ in seven- and nine-fold coordination is 1.06 and $1.18 \AA$, respectively (Shannon, 1976). This means that large cations preferentially occupy the larger Cal site.

Monovalent ion impurities including $\mathrm{Li}^{+}, \mathrm{Na}^{+}, \mathrm{K}^{+}$, and $\mathrm{Rb}^{+}$ have been reported in natural apatites (Young et al., 1969; Hughes et al., 1991; Simonetti et al., 2008), but only $\mathrm{Na}^{+}$is a common minor constituent. The others all occur at very low concentrations in natural apatites (Pan and Fleet, 2002). These monovalent ions usually reside in the Cal site (Table 1), and for charge balance reasons, their incorporation involves the presence of other trace ions (groups) such as $\mathrm{REE}^{3+}$ or $\mathrm{SO}_{4}^{2-}$ (Fleet and Pan, 1997; Sha and Chappell, 1999). REE ${ }^{3+}$ and $\mathrm{Y}^{3+}$, which can occur at significant concentrations (up to $27 \mathrm{wt}$ $\% \mathrm{REE}_{2} \mathrm{O}_{3}$; Zirner et al., 2015), are very compatible in apatite and prefer the Ca2 site (Fleet and Pan, 1995; Fleet et al., 2000; Klemme and Dalpé, 2003; Prowatke and Klemme, 2006). The

Table 1. Radius and Site Occupancy of Common Impurity Cations in Apatites

\begin{tabular}{|c|c|c|c|c|}
\hline Cation & Cal site: ${ }^{\mathrm{IX}} \mathrm{Ca}^{2+}(\AA)$ & Ca2 site: ${ }^{\mathrm{VII}} \mathrm{Ca}^{2+}(\AA)$ & Site preference & Reference \\
\hline $\mathrm{Ca}^{2+}$ & 1.18 & 1.06 & Stoichiometric & \\
\hline $\mathrm{Sr}^{2+}$ & 1.31 & 1.21 & Ca2 (almost exclusively) & $1,2,3$ \\
\hline $\mathrm{Ba}^{2+}$ & 1.47 & 1.38 & $\mathrm{Ca} 2$ & 4 \\
\hline $\mathrm{Mg}^{2+}$ & $0.89(\mathrm{VIII})$ & $0.72(\mathrm{VI})$ & Possibly Cal in REE-rich enviroment & 5 \\
\hline $\mathrm{Mn}^{2+}$ & $0.96(\mathrm{VIII})$ & 0.9 & Cal (may negatively correlate with $\mathrm{Cl}$ content) & $6,7,8,9$ \\
\hline $\mathrm{Fe}^{2+}$ & $0.92(\mathrm{VIII})$ & 0.78 (VI, HS) & $\mathrm{Ca} 1$ or $\mathrm{Ca} 2$ in $\mathrm{Fe}$-poor environment & 10 \\
\hline $\mathrm{Eu}^{2+}$ & 1.3 & 1.2 & $\mathrm{Ca} 2$ (similar behavior to $\mathrm{Eu}^{3+}$ ) & $2,11,12$ \\
\hline $\mathrm{Pb}^{2+}$ & 1.35 & 1.23 & $\mathrm{Ca} 2$ & 13,14 \\
\hline $\mathrm{Na}^{+}$ & 1.24 & 1.12 & $\mathrm{Cal}$ & 15,16 \\
\hline $\mathrm{Y}^{3+}$ & 1.075 & 0.96 & $\mathrm{Ca} 2$ & $2,11,12$ \\
\hline $\mathrm{REE}^{3+}(\mathrm{La}-\mathrm{Lu})$ & $1.042-1.216$ & $0.925-1.10$ & $\mathrm{Ca} 2$ & $2,11,12$ \\
\hline $\mathrm{Th}^{4+}$ & 1.09 & $0.94(\mathrm{VI})$ & $\mathrm{Ca} 1$ or $\mathrm{Ca} 2$ & 17 \\
\hline $\mathrm{U}^{4+}$ & 1.05 & 0.95 & $\mathrm{Ca} 1$ or $\mathrm{Ca} 2$ & 17 \\
\hline $\mathrm{Zr}^{4+}$ & 0.89 & 0.78 & Incompatible & 18 \\
\hline
\end{tabular}

Cation radii data are from Shannon (1976), site preference references: 1 = Sudarsanan and Young (1974), 2 = Hughes et al. (1991), 3 = Rakovan and Hughes (2000), 4 = Khudolozhkin et al. (1973), 5 = Ito (1968), 6 = Ryan et al. (1972), 7 = Warren and Mazelsky (1974), $8=$ Ercit et al. (1994), $9=$ Miles et al. (2014), 10 = Khudolozhkin et al. (1974), $11=$ Fleet and Pan (1995), 12 = Fleet et al. $(2000), 13=$ Engel et al. $(1975)$, $14=$ Verbeeck et al. (1981), 15 = Fleet and Pan (1997), 16 = Sha et al. (1999), 17 = Baumer et al. (1983), 18 = Prowatke and Klemme (2006) 
$\mathrm{SiO}_{4}^{4-}$ group, which occupies the site of $\mathrm{PO}_{4}^{3-}$, is a common charge compensator for $\mathrm{REE}^{3+}$ and $\mathrm{Y}^{3+}$ (Hughes et al., 1991; Sha and Chappell, 1999; Wang et al., 2014). Possible charge compensating reactions associated with trace element substitution include (Ito, 1968; Roeder et al., 1987; Rønsbo, 1989; Fleet and Pan, 1995; Serret et al., 2000; Chen et al., 2002):

$$
\begin{aligned}
\mathrm{REE}^{3+}+\mathrm{M}^{+} & =2 \mathrm{Ca}^{2+} \\
\mathrm{REE}^{3+}+\mathrm{SiO}_{4}^{4-} & =\mathrm{Ca}^{2+}+\mathrm{PO}_{4}^{3-} \\
\mathrm{REE}^{3+}+\mathrm{X}^{2-} & =\mathrm{Ca}^{2+}+\mathrm{F}^{-} \\
2 \mathrm{REE}^{3+}+ & =3 \mathrm{Ca}^{2+}
\end{aligned}
$$

For divalent cations, the most common minor and trace elements in natural apatites include $\mathrm{Sr}^{2+}, \mathrm{Ba}^{2+}, \mathrm{Mg}^{2+}, \mathrm{Mn}^{2+}, \mathrm{Fe}^{2+}$, $\mathrm{Eu}^{2+}$ and $\mathrm{Pb}^{2+}$, and due to the same charge and similar cation sizes to $\mathrm{Ca}^{2+}$ (Table 1), they can be incorporated in apatites from several parts per million (ppm) to several weight percent (Rakovan and Hughes, 2000; Pan and Fleet, 2002; Piccoli and Candela, 2002; Hughes et al., 2004).

The most abundant tetravalent cations in natural apatites are $\mathrm{Th}^{4+}$ and $\mathrm{U}^{4+}$, with contents that range from a few $\mathrm{ppm}$ to thousands of ppm (Sha and Chappell, 1999; Belousova et al., 2001, 2002; Tollari et al., 2008; Chu et al., 2009; Cao et al., 2012). Baumer et al. (1983) showed that one $\mathrm{Th}^{4+}$ or $\mathrm{U}^{4+}$ ion and a Ca vacancy can substitute for two $\mathrm{Ca}^{2+}$ ions.

$$
\mathrm{Th}^{4+}\left(\mathrm{U}^{4+}\right)+\square=2 \mathrm{Ca}^{2+}
$$

In natural apatites, the $\mathrm{PO}_{4}^{3-}$ group can be replaced by $\mathrm{VO}_{4}^{3-}$, $\mathrm{AsO}_{4}^{3-}, \mathrm{SiO}_{4}^{4-}, \mathrm{SO}_{4}^{2-}$ and $\mathrm{CO}_{3}^{2-}$ groups (Sudarsanan et al., 1977; Rønsbo, 1989; Hughes and Drexler, 1991; Binder and Troll, 1989; Peng et al., 1997; Comodi et al., 1999; Persiel et al., 2000). To balance the charge difference with substitutions (e.g., $\mathrm{SiO}_{4}^{4-}$ and $\mathrm{SO}_{4}^{2-}$ ), the following substitutions have been proposed (Rouse and Dunn, 1982; Peng et al., 1997):

$$
\begin{gathered}
\mathrm{SO}_{4}^{2-}+\mathrm{SiO}_{4}^{4-}=2 \mathrm{PO}_{4}^{3-} \\
\mathrm{SO}_{4}^{2-}+\mathrm{Na}^{+}=\mathrm{PO}_{4}^{3-}+\mathrm{Ca}^{2+}
\end{gathered}
$$

It has been shown that $\mathrm{MnO}_{4}^{3-}$ can replace $\mathrm{PO}_{4}^{3-}$ in synthetic $\mathrm{Cl}$ apatites (Kingsley et al., 1965), but Hughes et al. (2004) found that $\mathrm{MnO}_{4}^{3-}$ does not exceed $5 \%$ of the total Mn content in natural apatites.

\section{Geologic Setting of Mineral Deposits}

The central role of global tectonics in the formation and distribution of mineral deposits is firmly established and is the basis for their classification (e.g., Guilbert and Park, 1986; Groves et al., 2005; Lydon, 2007). Although evidence of the linkage is principally Phanerozoic in age, most workers agree that Phanerozoic tectonic models are applicable to the Proterozoic and probably the Archean (e.g., Kerrich and Polat, 2006; Condie and Kroner, 2008). The most productive geologic environment for the formation of metalliferous mineral deposits is destructive plate margins (Guilbert and Park, 1986; Groves and Bierlein, 2007). Specifically, volcanic arcs and back arcs that were built upon, or accreted to, continental margins during supercontinent assembly (e.g., Barley and Groves, 1992; Lydon, 2007; Goldfarb et al., 2010; Cawood and Hawksworth, 2015). Accordingly, most of the mineral deposit types considered in this study formed at destructive plate margins and are directly related to magmatic and/or associated convective hydrothermal systems. These deposits include porphyry, epithermal, skarn, orogenic $\mathrm{Au}$, orogenic $\mathrm{Ni}-\mathrm{Cu}$, and iron oxide-apatite systems. Constructive plate margins are not highly productive for economic mineral deposits, even though spreading centers in oceanic crust are the most common site for modern metalliferous hydrothermal deposition (e.g., Lydon, 2007). Mineral deposits that form in or on continental crust during the long periods of supercontinent cohesion include carbonatites, diamonds, and possibly some styles of iron oxide $\mathrm{Cu}-\mathrm{Au}$ systems.

After classification by tectonic environment, major mineral deposit types are characterized by commodity, morphology, alteration, ore mineralogy, and host-rock associations (e.g., Hedenquist et al., 2000; Goodfellow, 2007). These characteristics form the basis of the standard ore deposit models briefly summarized below. Detailed information on the actual deposits sampled for this study, including their name, age, location, material sampled, and apatite characteristics are given in Table 2, Appendix 1, and Appendix Tables 1 and 2.

\section{Porphyry deposits}

Porphyry deposits are large, low-grade $\mathrm{Cu}, \mathrm{Mo}, \mathrm{Au}, \mathrm{Ag}, \mathrm{W}$, and/or Sn magmatic-hydrothermal deposits spatially associated with felsic to intermediate porphyritic intrusions formed within $6 \mathrm{~km}$ of the paleosurface in continental- and islandarc settings (Seedorff et al., 2005; Sillitoe, 2010). The deposits typically contain hundreds of millions of tonnes of ore, but the grades are low (generally $<1 \% \mathrm{Cu}$ and $<0.1 \% \mathrm{Mo}$ ). Porphyry Mo and Sn-W deposits are associated with A-type and S-type granites, respectively, which form in back-arc continental environments (Christiansen and Keith, 1996; Newberry, 1998). Porphyry $\mathrm{Cu}-\mathrm{Mo}$ and $\mathrm{Cu}-\mathrm{Au}$ deposits are derived from I-type granites (Loucks, 2014; Dilles et al., 2014) that possess variable alkalinity (e.g., Barr et al., 1976; Lang et al., 1995), degrees of silica saturation (Seedorff et al., 2005), and oxidation states (Rowins, 2000; Smith et al., 2012; Cao et al., 2014). Porphyry deposits are rare in Proterozoic and Archean rocks, possibly due to differences in the style of plate tectonics and diminished preservation potential of older orogens (e.g., Groves et al., 2005; Richards and Mumin, 2014).

\section{Skarn deposits}

Skarn deposits occur in rocks of all ages and are characterized by pervasive calc-silicate alteration (typically garnet and pyroxene) of carbonate-rich rocks by magmatic-hydrothermal fluids at the margins of felsic intrusions (e.g., Einaudi et al., 1981; Meinert et al., 2005). There are seven major metallic skarn types ( $\mathrm{Fe}, \mathrm{Au}, \mathrm{Cu}, \mathrm{Pb}-\mathrm{Zn}, \mathrm{W}, \mathrm{Mo}$, and $\mathrm{Sn})$ with many being parts of larger porphyry systems (Meinert et al., 2005; Ray, 2013). The porphyry linkage may be obscure for skarn deposits forming distal to pluton margins, and some $\mathrm{W}$ and $\mathrm{Sn}$ skarns lack any apparent association with porphyry-style mineralization. Skarn deposits are commonly polymetallic with a wide range of grades and tonnages.

\section{Epithermal Au-Ag deposits}

Epithermal Au-Ag deposits consist of quartz veins and sulfide disseminations that typically formed within $1.5 \mathrm{~km}$ of the Earth's surface (Cooke and Simmons, 2000). The ores are dominated by precious metals $(\mathrm{Au}, \mathrm{Ag})$, but some deposits may contain significant amounts of the base metals $\mathrm{Cu}, \mathrm{Pb}$, 
Table 2. Summary of Samples and Apatite Analyses

\begin{tabular}{|c|c|c|c|c|}
\hline Classification & Deposit/locality name & Rock samples $^{1}$ & Analyses & Total analyses \\
\hline \multirow[t]{3}{*}{ Alkalic porphyry $\mathrm{Cu}-\mathrm{Au}$} & Dobbin (Alfy), BC & 4 & 59 & \multirow[t]{3}{*}{145} \\
\hline & Mount Polley (Cariboo-Bell), BC & 2 & 48 & \\
\hline & Shiko (Red Gold), BC & 3 & 38 & \\
\hline Porphyry $\mathrm{Cu}-\mathrm{Au}$ & Kemess South (Ron), BC & 2 & 33 & 33 \\
\hline Porphyry-related $\mathrm{Cu}-\mathrm{Au}$ breccia & Willa (L.1529; Rockland Group), BC & 1 & 34 & 34 \\
\hline \multirow[t]{4}{*}{ Porphyry $\mathrm{Cu}-\mathrm{Mo}$} & Gibraltar, BC & 1 & 6 & \multirow{4}{*}{55} \\
\hline & Highmont (Highmont mine), BC & 1 & 26 & \\
\hline & Highland Valley Copper (Valley), BC & 1 & 7 & \\
\hline & Lornex (Lornex mine), BC & 1 & 16 & \\
\hline \multirow[t]{4}{*}{ Porphyry Mo } & Endako (Endako mine), BC & 1 & 3 & \multirow[t]{4}{*}{61} \\
\hline & Boss Mountain (Brynnor), BC & 1 & 11 & \\
\hline & Cassiar Moly, BC & 1 & 24 & \\
\hline & Brenda (Brenda mine), BC & 1 & 23 & \\
\hline IOCG breccia & Wernecke, Yukon & 4 & 44 & 44 \\
\hline \multirow[t]{3}{*}{ Kiruna-type } & Aoshan, China & 5 & 37 & \multirow[t]{3}{*}{267} \\
\hline & Great Bear (Rainy Lake pluton), NWT & 1 & 13 & \\
\hline & Durango, Mexico & 1 & 217 & \\
\hline Orogenic Ni-Cu & Jason, BC & 1 & 28 & 28 \\
\hline \multirow[t]{4}{*}{ Orogenic Au } & Congress (Lou), BC & 1 & 15 & \multirow[t]{4}{*}{45} \\
\hline & Dentonia (Dentonia mine), BC & 1 & 2 & \\
\hline & Seabee, Saskatchewan & 2 & 23 & \\
\hline & Kirkland Lake, Ontario & 1 & 5 & \\
\hline \multirow[t]{2}{*}{ Au-Co skarn } & Minyari, Australia & 2 & 12 & \multirow[t]{2}{*}{15} \\
\hline & Racine, $\mathrm{BC}$ & 1 & 3 & \\
\hline Cu skarn & Little Bittle (Little Billy), BC & 1 & 1 & 1 \\
\hline Pb-Zn skarn & Gold Canyon, BC & 1 & 1 & 1 \\
\hline \multirow[t]{2}{*}{ W skarn } & Molly (L.14232; Molybdenite), BC & 1 & 26 & \multirow[t]{2}{*}{28} \\
\hline & O'Callagham's, Australia & 1 & 2 & \\
\hline \multirow{2}{*}{ Epithermal Au-Ag } & Cinola (Specogna/Harmony), BC & 1 & 1 & \multirow{2}{*}{9} \\
\hline & Cripple Creek, Colorado & 2 & 8 & \\
\hline Carbonatite & 29 intrusive complexes worldwide & 30 & 70 & 70 \\
\hline \multirow[t]{3}{*}{ MOR (unmineralized) } & Southwest Indian Ridge (Atlantis Bank) & 2 & 19 & \multirow[t]{3}{*}{52} \\
\hline & Mid Atlantic Ridge & 2 & 20 & \\
\hline & East Pacific Rise & 3 & 13 & \\
\hline \multirow[t]{5}{*}{ Intrusive rock (unmineralized) } & Kirkland Lake, Ontario (pyroxenite, monzonite, and syenites) & 8 & 160 & \multirow[t]{5}{*}{251} \\
\hline & Kandaguba, Russia (apatite-calcite-feldspar-biotite ijolite) & 1 & 3 & \\
\hline & Blu Starr, BC (metamorphosed alkali-feldspar syenite) & 1 & 1 & \\
\hline & Thiemer Creek pluton, BC (diorites and granodiorites) & 3 & 78 & \\
\hline & Beaver Cove pluton, BC (diorites and granodiorites) & 1 & 9 & \\
\hline Other & First Mine Discovery, Madagascar (pegmatite) & 1 & 230 & 230 \\
\hline
\end{tabular}

${ }^{1}$ All samples from mineral deposits are from mineralized zones

and $\mathrm{Zn}$ (Hedenquist et al., 2000). The deposits commonly are associated with centers of magmatism and volcanism that also host large porphyry $\mathrm{Cu}-\mathrm{Au}$ deposits. Epithermal $\mathrm{Au}-\mathrm{Ag}$ deposits are distinguished on the basis of the sulfidation state of the sulfide mineralogy as belonging to high-, intermediate-, or lowsulfidation subtypes. The high-sulfidation subtypes are large, low-grade (typically $<1 \mathrm{~g} / \mathrm{t} \mathrm{Au}$ ), disseminated orebodies and form from magmatic-hydrothermal fluids immediately above porphyry $\mathrm{Cu}-\mathrm{Au}$ deposits. In contrast, low-sulfidation subtypes form distal to the porphyry system at deeper levels, where mixing with cool meteoric waters produces "bonanza" grade $\mathrm{Au}-\mathrm{Ag}$ veins containing hundreds of ounces of Ag and tens of ounces of $\mathrm{Au}$ (Simmons et al., 2005; Duuring et al., 2009a). Intermediate-sulfidation subtypes occur in the transitional zone between high- and low-sulfidation subtypes and contain abundant base metals $(\mathrm{Cu}, \mathrm{Pb}$, and $\mathrm{Zn})$, in addition to $\mathrm{Au}$ and $\mathrm{Ag}$.

\section{Orogenic Au deposits}

Orogenic Au deposits encompass all epigenetic, structurally hosted, lode gold vein systems in metamorphic terranes (Groves et al., 1998). They consist of auriferous quartz-carbonate-sulfide veins and were previously known as Archean lode Au, mesothermal $\mathrm{Au}$, greenstone $\mathrm{Au}$, mother lode $\mathrm{Au}$, turbidite-hosted $\mathrm{Au}$, and slate-belt $\mathrm{Au}$, among others. Orogenic $\mathrm{Au}$ deposits occur in regionally metamorphosed terranes of all ages and are second only to paleoplacers for annual global Au production (Dubé and Gosselin, 2007). Ores form during compressional to transpressional deformation at convergent plate margins in accretionary and collisional orogens (e.g., Kerrich et al., 2000). The average Au grade worldwide is $7.6 \mathrm{~g} / \mathrm{t}$ with deposits normally containing between 20 and $40 \mathrm{Mt}$ of ore (Dubé and Gosselin, 2007). Deposits form on or near major crustal shear zones with mineralization commonly localized in re-activated secondand third-order structures (Hagemann and Cassidy, 2000). Most orebodies form at midcrustal depths (5-10 km) close to the upper greenschist-lower amphibolite facies transition, although deeper $(\sim 20 \mathrm{~km})$ and shallower $(\sim 5 \mathrm{~km})$ deposits are recognized (Groves, 1993). In some Archean terranes, especially those in the Superior Province of Canada, felsic plutonism is directly involved in the genesis of orogenic Au deposits (e.g., Rowins et al., 1993; Robert, 2001; Ispolatov et al., 2008; Bigot and Jebrak, 2015). 
Iron oxide Cu-Au and Kiruna-type iron oxide-apatite deposits

Iron oxide $\mathrm{Cu}-\mathrm{Au}$ (IOCG) deposits comprise a diverse group of deposits better viewed as iron oxide-associated deposits (Groves et al., 2010). Kiruna-type iron oxide-apatite deposits (IOA), hereafter referred to as "Kiruna-type," are sometimes classified as the $\mathrm{Cu}$-poor end member of the IOCG class, although their genetic connection remains controversial (Knipping et al., 2015a, b). The type location for IOCG deposits is the giant Olympic Dam Cu-U-Au deposit in South Australia (Hitzman et al., 1992). The essential criteria for IOCG deposits are as follows: (1) are formed by magmatic-hydrothermal processes, (2) have $\mathrm{Cu} \pm \mathrm{Au}$ as economic metals, (3) are structurally controlled - commonly with breccias, (4) are surrounded by alteration and/or brecciation zones normally more regional in scale relative to economic mineralization, (5) have depleted $\mathrm{SiO}_{2}$ content of altered wall rocks, (6) have abundant low-Ti iron oxides or iron silicates, and (7) have a close temporal, but not apparent spatial, relationship to causative intrusions (Groves et al., 2010). This suite of characteristics distinguishes IOCG deposits from most other hydrothermal $\mathrm{Cu}-\mathrm{Au}$ deposits that are commonly dominated by pyrite with accessory copper sulfides and gold (e.g., most porphyry and VMS deposits) and/or have quartz veins or silicification together with iron oxides. Precambrian deposits dominate the IOCG group and their tectonic setting at formation was most likely anorogenic, with magmatism and associated hydrothermal activity driven by mantle underplating and/or plumes (Groves et al., 2010). Hunt et al. (2011), however, recently proposed that the Wernecke IOCG breccias are unrelated to magmatism, but are the result of periodic overpressuring of formational and metamorphic waters due to the weight of the overlying sedimentary rocks. In contrast to IOCG deposits, Kiruna-type deposits (e.g., Kiruna and Gransgerberg in Sweden; El Romeral, Los Colorados, Cerro Negro in northern Chile) occur in convergent margin settings, typically lack economic $\mathrm{Cu} \pm \mathrm{Au}$, and are associated with calc-alkaline magmatism (Kerrich et al., 2005; Knipping et al., 2015b).

\section{Orogenic $\mathrm{Ni}-\mathrm{Cu} \pm \mathrm{PGE}$ deposits}

Orogenic $\mathrm{Ni}-\mathrm{Cu} \pm$ platinum group element (PGE) deposits are a newly recognized type of deposit. Unlike many of the world's giant magmatic Ni-Cu \pm PGE deposits such as Noril'sk and Pechenga (Russia), Thompson and Voisey's Bay (Canada), and Jinchuan (China), that occur in extensional settings (Naldrett, 2004), several subduction-related magmatic arcs also host significant $\mathrm{Ni}-\mathrm{Cu} \pm$ PGE deposits (Casquet et al., 2001; Ortega et al., 2004; Pina et al., 2006). The best known of these deposits is Aguablanca (Spain), a 15.7-Mt deposit grading $0.66 \% \mathrm{Ni}, 0.46 \% \mathrm{Cu}, 0.47 \mathrm{~g} / \mathrm{t}$ PGEs, and $0.13 \mathrm{~g} / \mathrm{t} \mathrm{Au}$ (Pina et al., 2006). In Canada, small Ni-Cu \pm PGE deposits such as Lac Edouard and Giant Mascot formed from mafic and ultramafic intrusions emplaced in island-arc settings (Sappin et al., 2011, 2012; Manor et al., 2016).

\section{Carbonatites}

Carbonatites are igneous rocks that contain at least $50 \%$ primary carbonates (e.g., Bell, 1989, 2005). They are classified according to their modal or chemical compositions (Woolley and Kemp, 1989). More than 500 occurrences have been identified, with ages that range from the late Archean to the present (Woolley and Kjsarsgaard, 2008). Carbonatites occur in deep-seated, shallow, and extrusive environments on all continents, including Antarctica. Although most carbonatites are spatially associated with a variety of silicate rocks (e.g., nephelinites, phonolites, melilitites, ultramafic lamprophyres, or their plutonic equivalents) of similar age, they may also occur as isolated intrusions. Most intrusive carbonatite complexes are surrounded by a zone of metasomatically altered country rocks showing enrichment in $\mathrm{Na}$ and/or $\mathrm{K}$. These rocks are made up of metasomatic feldspar, sodic pyroxenes, and alkali amphiboles and are termed "fenites." Carbonatites typically form in intracratonic rift settings or in association with major faults and large-scale domal swells (Bell et al., 1998; Bell, 2005). Carbonatites are enriched in REE, Ba, Sr, F, P, Nb, U, Th, and sometimes Zr, V, Ti, Ta, and base metals $\mathrm{Cu}, \mathrm{Pb}$, and $\mathrm{Zn}$ (Rankin, 2005). Presently, mineral production from carbonatites is dominated by $\mathrm{Cu}$ and by-products $\mathrm{Zr}, \mathrm{Fe}$, apatite, Ni, Au, and platinum group elements (PGEs) from the Phalaborwa mine in South Africa (Rankin, 2005). Carbonatites also account for most of the world's current production of $\mathrm{Nb}, \mathrm{REE}$, a significant proportion of its phosphate and fluorite production (Rankin, 2005).

\section{Others}

For completeness of study, we also examined ores and alteration zones associated with volcanogenic massive sulfide (VMS) deposits and sedimentary-exhalative (SEDEX) deposits for hydrothermal apatite. Our investigation revealed that hydrothermal apatite was exceedingly rare in these samples, confirming that it is not a useful accessory mineral for identifying these types of deposits.

\section{Samples}

In this study, we examined 230 rock samples from different deposits and rock types (App. 1). Many of the rock samples are from deposits located in British Columbia, Canada, part of the North American Cordillera with an exceptional diversity of deposit types (Fig. 1; Table 2). Apatite grains were analyzed from 97 rock samples. Most of the apatite-bearing samples are from porphyry $\mathrm{Cu} \pm \mathrm{Mo} \pm \mathrm{Au}$, IOCG breccia, Kiruna-type, orogenic Au, Au-Co skarn and W skarn deposits, and carbonatites. Orogenic Ni-Cu \pm PGE and epithermal Au-Ag deposits yielded few apatite grains. Igneous apatites also were recovered from 20 samples of fresh (unmineralized) igneous rock types in order to identify any systematic differences between apatites from the mineral deposits and their unmineralized hosts. The fresh igneous rocks sampled include clinopyroxenite, calcite ijolite, gabbro, diorite, syenite, alkali-feldspar syenite, quartz syenite, quartz monzonite, and granodiorite. Appendix Tables 1 and 2 provide the detailed descriptions of the rock samples and apatites studied, respectively.

\section{Experimental Methods}

\section{Sample preparation}

Thin sections for most samples (except samples from Southwest Indian Ridge, Mid-Atlantic Ridge, Great Bear, Aoshan, Durango, Madagascar, and all carbonatites) were examined 
(a)

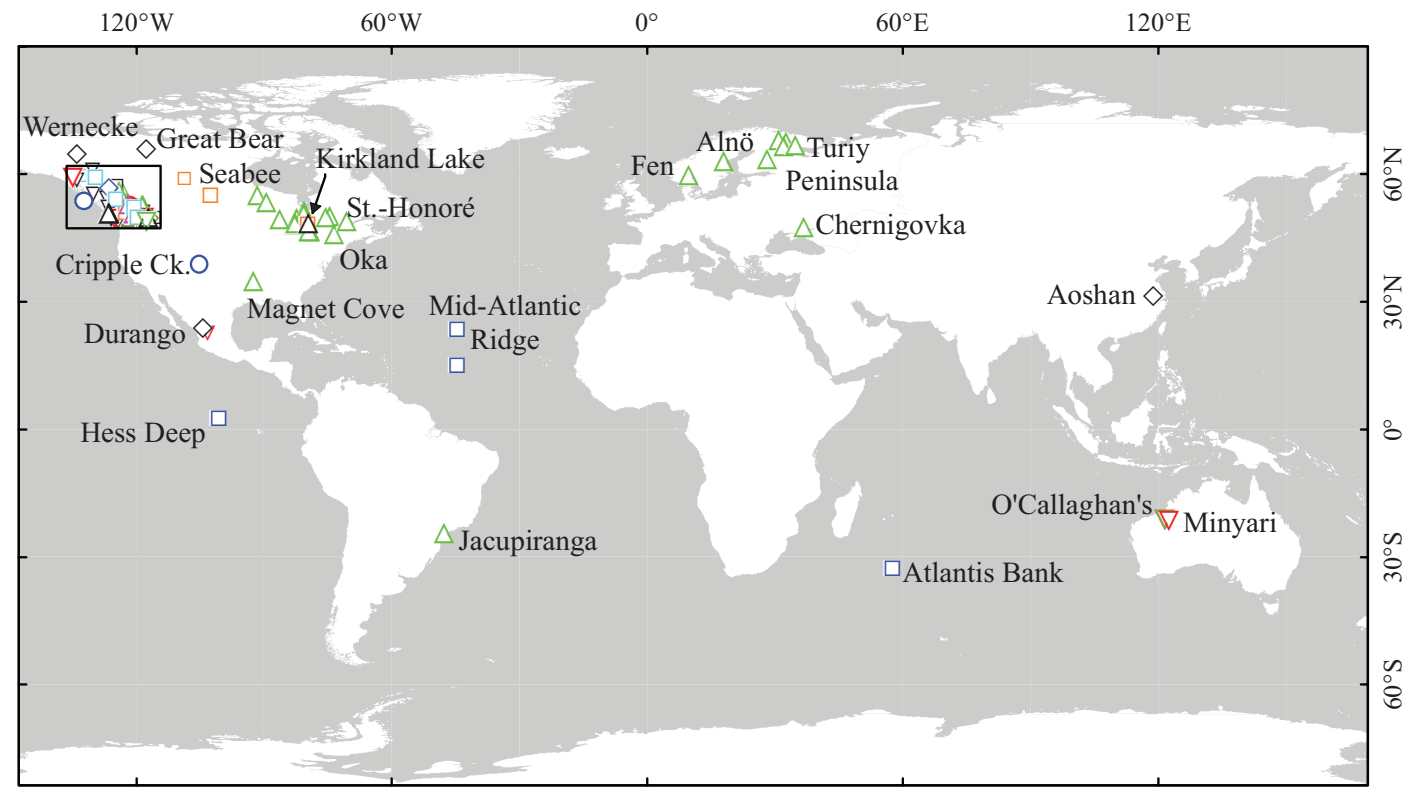

(b)

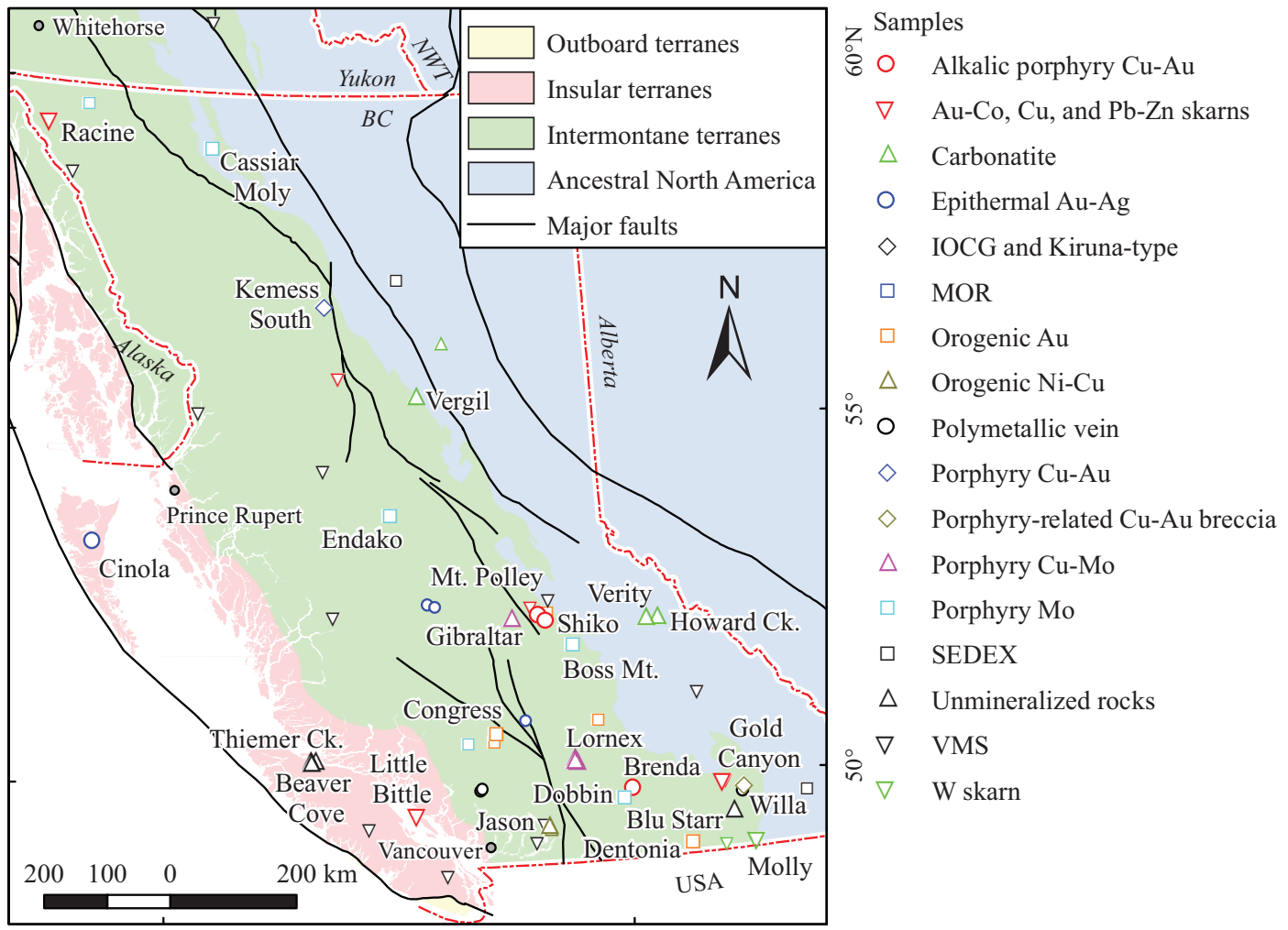

$130^{\circ} \mathrm{W}$

$120^{\circ}$

Fig. 1. Location of samples in this study. a) World map; box shows location of Figure 1b. b) British Columbia map, showing simplified geology after Colpron and Nelson (2011). The symbols on both maps represent deposits which were examined in this study; the larger symbols represent samples that yielded apatites investigated.

to estimate apatite abundance, morphology, and size (App. Table 2). Those samples containing apatites then underwent mineral separation. The separation process included the following seven steps.

1. Each rock sample (50-1,000 g) was crushed and pulverized to $<1$-mm fragments.
2. The crushed samples were sieved to separate the 250 - to $500-\mu \mathrm{m}$-size fraction; if no apatites were found in this fraction, the 180 - to $250-\mu \mathrm{m}$ fraction was used.

3. After the sieved fraction was washed and dried, a hand magnet was used to remove magnetic minerals from the sample.

4. Samples were then sequentially separated in tetrabromoethane (TBE) and methylene iodide (MI) to extract the 
fraction with a density between 2.97 and $3.32 \mathrm{~g} / \mathrm{cm}^{3}$. Samples were submerged in each heavy liquid for at least 15 minutes to ensure complete separation. Between samples, all glassware was washed thoroughly with acetone to avoid cross contamination.

5. The mid-density $\left(2.97-3.32 \mathrm{~g} / \mathrm{cm}^{3}\right)$ fraction was then processed by Frantz isodynamic separator twice (at $0.1-0.5$ and $1.5 \mathrm{~A}$ ) to separate nonmagnetic minerals from paramagnetic minerals. In addition, a few apatite grains from pegmatitic samples were separated manually due to their large size (1-5 mm) (App. Table 2).

6. Apatite grains that appeared clear and free of inclusions were hand-picked from the nonmagnetic fraction under a binocular microscope and mounted in epoxy pucks for electron microprobe analysis (EMPA) and laser ablation-inductively coupled plasma mass spectrometry (LA-ICPMS).

7. The grain mounts were polished by hand using BuehlerMet II lapping papers P400, P1200, P4000, and Buehler lapping powder 1 and $0.3 \mu \mathrm{m}$. All grain mounts were rinsed thoroughly using deionized water between polishing steps and cleaned in an ultrasonic bath for approximately 30 minutes prior to analysis.

\section{EMPA}

The EMPA was performed on a fully automated Cameca SX50 Electron Microprobe, equipped with four wavelengthdispersive spectrometers, at the Department of Earth, Ocean and Atmospheric Sciences, University of British Columbia (UBC). Before each analysis, the apatite grains were examined by back-scattered electron (BSE) imaging; no prominent zonation was observed. Although some apatites may display complex zoning in cathodoluminescence imaging (e.g., Bouzari et al., 2011), detailed investigation of withingrain chemical variations was beyond the scope of this study, which characterizes apatite chemistry between many different types of rock and deposits. At least two spots analyzed on random apatite grains (App. Table 2) did not reveal any significant within-grain variations, consistent with the lack of zoning in BSE. The EMPA was done using the wavelengthdispersion mode with a $15-\mathrm{kV}$ excitation voltage, $10-\mathrm{nA}$ beam current, and $10-\mu \mathrm{m}$ beam diameter. Peak and background counting times were $20 \mathrm{~s}$ for $\mathrm{F}, \mathrm{S}, \mathrm{Cl}$, and $\mathrm{Fe}$, and $10 \mathrm{~s}$ for $\mathrm{Na}, \mathrm{Si}, \mathrm{P}$, and Ca. Fluorine was always measured on the first cycle because of migration during analysis. The background values for $\mathrm{F}$ were fixed and based on the first measured result in each analytical session. Data reduction was done using the "PAP" $\Phi(\rho Z)$ method (Pouchou and Pichoir, 1985). The following standards (locations), X-ray lines, and crystals were used: topaz (Topaz Valley, UT, USA), FK $\alpha$, TAP; albite (Rutherford mine, Amelia County, VA, USA), NaK $\alpha$, TAP; diopside (C.M. Taylor Company, locality unknown), SiK $\alpha$, TAP; apatite (Wilberforce, ON, Canada), PK $\alpha$, PET; barite (C.M. Taylor Company, locality unknown), SK $\alpha$, PET; scapolite (Lot 32, Con. XVII, Monmouth, ON, Canada), ClK $\alpha$, PET; apatite (Wilberforce, ON, Canada), CaK $\alpha$, PET; synthetic fayalite (Los Alamos National Laboratory, NM, USA), FeK $\alpha$, LIF. The use of apatite to calibrate $\mathrm{Ca}$ and $\mathrm{P}$ minimizes the matrix correction required.

The detection limits, based on counting statistics, were 0.11 wt $\%$ for $\mathrm{Ca}, 0.05$ to 0.12 wt $\%$ for $\mathrm{Na}, \mathrm{Si}, \mathrm{S}$, and $\mathrm{Cl}, 0.11$ to 0.16 wt $\%$ for $\mathrm{Fe}, 0.19$ wt $\%$ for $\mathrm{P}$, and 0.65 wt $\%$ for $\mathrm{F}$. The average precision $(2 \sigma$ relative $\%$ ) was $1 \%$ for $\mathrm{Ca}, 3 \%$ for $\mathrm{P}$, $40 \%$ for $\mathrm{Fe}, 20 \%$ for $\mathrm{Cl}, 29 \%$ for $\mathrm{S}, 27 \%$ for $\mathrm{Si}, 36 \%$ for $\mathrm{Na}$, and $17 \%$ for $\mathrm{F}$.

\section{LA-ICPMS analysis}

All ICPMS analyses were performed on a Thermo X-Series II (X7) quadrupole ICPMS at the School of Earth and Ocean Sciences, University of Victoria. For laser ablation analysis, a New Wave UP-213 was coupled to the X-Series II with helium as the carrier gas.

Appendix Table 3 lists the LA-ICPMS experimental conditions per analytical session. Separated apatite grains ( $\mathrm{n}=$ 793) were analyzed with a $30-\mu \mathrm{m}$ laser spot diameter (in some cases $40 \mu \mathrm{m}$ ), a pulse rate of $10 \mathrm{~Hz}$, and measured fluence ranged from 6.6 to $10.8 \mathrm{~J} \cdot \mathrm{cm}^{-2}$. For thin sections, the pulse rate $(2-5 \mathrm{~Hz})$ and energy (fluence $\left.=1.4-2.8 \mathrm{~J} \cdot \mathrm{cm}^{-2}\right)$ were reduced to avoid burning through the samples (total 127 analyses). A pre-ablation warm-up of $5 \mathrm{~s}$ was used to avoid unstable laser energy at the beginning of each ablation. All LA-ICPMS spectra were recorded for $120 \mathrm{~s}$ including $\sim 30 \mathrm{~s}$ gas blank before ablation started, $60 \mathrm{~s}$ during ablation, and $\sim 30 \mathrm{~s}$ post ablation. At least $60 \mathrm{~s}$ of gas flushing was allowed between analyses. The ICPMS was optimized to maximize sensitivity and minimize oxide formation. Forward RF was 1,400 watts. The dwell time was $3 \mathrm{~ms}$ for all REE elements and $5 \mathrm{~ms}$ for all other elements (App. Table 3).

Calcium was used as the internal standard for LA-ICPMS calibration. Calcium concentrations for most samples were determined directly by EMPA. Where direct EMPA data were not available, the median Ca content from other apatites from the same sample was used in the data-reduction calculations; and when no EMPA data were available, ideal Ca content of fluorapatite (39.5 wt \%) was used (App. Table 4). NIST glasses 611, 613, and 615 (Jochum et al., 2011) were used as the external calibration standards. To determine the effect of the difference in matrix, and to determine experimental accuracy and precision, fragments of two large natural apatite crystals from Madagascar and Durango (Young et al., 1969; Thomson et al., 2012) were analyzed 230 and 217 times, respectively, and the analyte concentrations were also determined by solution ICPMS. Madagascar apatite was analyzed through all experiment sessions, and Durango apatite was analyzed with all samples except the apatites from carbonatites. A typical analysis session started with NIST glasses 615, 613, and 611, followed by Madagascar and Durango apatites, and then 6 to 7 unknowns and then all five standards were repeated. During the data reduction, time-resolved count rates were carefully checked and any spectra with spikes, indicating possible inclusions, were excluded.

As with EMPA, we analyzed at least two spots on randomly selected apatite grains to check within-grain homogeneity (App. Table 2). Although time-resolved count rates from continuous ablation traverses of some apatite grains showed systematic patterns suggesting zonation, the difference between within-grain spot analyses rarely exceeded analytical error (App. Table 4). This is partly because the scale of zonation is less than the laser spot diameter $(30-40 \mu \mathrm{m})$. Furthermore, count rates from manually selected signal region were averaged by the offline data reduction procedure for each element 
as follows: (1) selection of the time intervals for the background and signal region of each spectrum, (2) calculation of the mean CPS (count per second) of these intervals, (3) background correction of the signal CPS, (4) internal standard normalization, (5) drift correction using a linear drifting factor determined from repeat analysis of NIST 611, and (6) calibration using sensitivities for each element determined from the initial analyses of NIST 615, 613 and 611 in each load to achieve the concentration value of each element.

Initially, 48 trace elements were analyzed by LA-ICPMS during the first stage of reconnaissance analyses. This was reduced to 29 elements in order to maximize the total time collecting data for each element. The experimental precision was determined by repeat analyses of NIST glasses 611 and 613 and the Madagascar and Durango apatites. Based on NIST 613 and Durango and Madagascar apatite, the precision $(2 \sigma)$ for elements with concentrations ranging from dozens to several hundred $\mathrm{ppm}$ is $<10 \%$ for $\mathrm{Mn}, \mathrm{Sr}, \mathrm{Nb}, \mathrm{La}, \mathrm{Ce}, \mathrm{Pr}$, and $\mathrm{Nd}$; from 10 to $20 \%$ for $\mathrm{Y}, \mathrm{Zr}, \mathrm{Ba}, \mathrm{Pb}, \mathrm{Th}, \mathrm{U}$, and the rest of the REEs; and $>20 \%$ for Mg, V, and As. For NIST 611, which contains higher concentrations of all elements than NIST 613 , the precision is 6 to $10 \%$ for $\mathrm{Mg}, \mathrm{Fe}, \mathrm{Cu}, \mathrm{Zn}, \mathrm{As}, \mathrm{W}$, and $\mathrm{Pb}$, and $<6 \%$ for other elements. The precision determined from NIST 615 shows that elements with concentrations close to the detection limit can be ranked as qualitative analyses (Table 3).

Due to instrument variations, the detection limit has been determined for each element per load (one load is one session) using equation (8):

$$
\mathrm{LOD}=\frac{3 \sigma \text { background }}{\text { Sensitivity (per analyte, per session) }}
$$

where $3 \sigma$ background is 3 times the standard deviation of the signal for a given element collected before ablation for each sample (gas blank), and Sensitivity is the slope of calibration curve (i.e. internal-standard- and drift-corrected cps vs. true concentration for external standards) determined from NIST 615,613 , and 611 per element in each session.

Except during the experimental sessions that used lower laser energy, the detection limits are typically $<900 \mathrm{ppm}$ for $\mathrm{Fe}$; $<70 \mathrm{ppm}$ for $\mathrm{Mg}$ and $\mathrm{Cu} ;<40 \mathrm{ppm}$ for $\mathrm{Mn} ;<20 \mathrm{ppm}$ for $\mathrm{V}, \mathrm{Zn}, \mathrm{As}, \mathrm{Sr}$ and Mo; $<10 \mathrm{ppm}$ for Rb, Ba, Ce, Nd, Sm, and $\mathrm{Gd}$; and $<5 \mathrm{ppm}$ for the remaining elements (App. Table 3). Although Fe was analyzed in some apatite samples by both LA-ICPMS $(\mathrm{n}=391)$ and EMPA $(\mathrm{n}=807)$, most of the results were below the detection limits (App. Table 4). Therefore, Fe results will not be discussed here.

\section{Solution ICPMS analysis}

The Durango and Madagascar apatites were analyzed by solution ICPMS as a test of the accuracy of the LA-ICPMS results. Large fragments of both Durango and Madagascar apatite crystals were crushed and triplicate samples of each were obtained for analysis by randomly selecting 20 to 30 fragments $(\sim 40 \mathrm{mg})$. In the same run, a concentrate of apatite of the certified reference material CTA-AC-1 (Dybczynski et al., 1991) was also analyzed in triplicate to test the accuracy of the solution ICPMS results. Samples and blanks were treated the same way. All were digested in $16 \mathrm{~N} \mathrm{HNO}_{3}$ (Anachemia
Environmental Grade), then diluted to $120 \mathrm{~mL}$ with $18 \mathrm{M} \Omega$ ultrapure water, in a metal-free Class 100 total exhaust fume hood prior to analysis on the X-Series II ICPMS in CCT-KED mode (cell gas $=7 \% \mathrm{H}_{2}$ in $\mathrm{He}$ ). Indium was added on-line as the internal standard, and calibration was by standard addition. The results (Table 3) show good agreement between the measured and certified values of CTA-AC-1, and between the average solution ICPMS and LA-ICPMS values for both Durango and Madagascar apatites excluding As in the Madagascar apatite.

\section{Results}

A total of 922 analyses from 902 apatite grains, excluding the Durango and Madagascar apatites, were performed by LAICPMS in this study. A smaller subset of 783 epoxy-mounted grains also was analyzed by EMPA for major and minor elements (Table 4; App. Table 4). To account for detection limit variance between different LA-ICPMS sessions (App. Table 3), an arbitrary replacement value equal to half of the lowest detection limit per analyte (Table 3) was used for results less than the detection limit. Results below abnormally high DL were discarded, but complete raw analytical data are given in Appendix Table 4B.

\section{Calcium and phosphorous}

Calcium and phosphorous are both major elements in apatites and do not show large variations. In most of the apatites, Ca contents range from 4.66 to 5.09 atoms per formula unit (apfu) (36.7-40.6 wt \% Ca). Apatites from unmineralized rocks, except mid-ocean ridge-related samples (referred to as MOR apatites), generally have lower Ca contents than those of apatites from ore deposits, except for Kiruna-type deposits, which approach the ideal fluorapatite Ca content (39.7 wt \%). Apatites from porphyry-related $\mathrm{Cu}-\mathrm{Au}$ breccia, $\mathrm{Au}$-Co skarn, and W skarn deposits have the highest Ca contents (Fig. 2). The Ca contents show a negative correlation with the sum of main trace cation elements (Fig. 3a). The $\mathrm{P}$ contents range from 2.78 to 3.07 (apfu) (15.2-19.6 wt \% P) in the studied apatites.

\section{Fluorine and chlorine}

The EMPAs have a relatively high detection limit $(0.7 \mathrm{wt} \%)$ and poor precision $(17 \%)$ for $\mathrm{F}$ compared with the quantitative data for other elements. Consequently, F contents are considered semiquantitative (Table 4). In addition, about $55 \%$ of the analyzed apatites have $\mathrm{F}$ in excess of the maximum $\mathrm{F}$ concentration of $\sim 3.77$ wt \% in end-member fluorapatite, indicating problematic EMPAs, or excess $\mathrm{F}$ bound to $\mathrm{CO}_{3}^{2-}$ (Piccoli and Candela, 2002). Assuming that $\mathrm{F}^{-}, \mathrm{Cl}^{-}$, and $\mathrm{OH}^{-}$fill the anion site, studied apatites indicate mainly $\mathrm{F}-\mathrm{OH}$ exchange. Apatites in hydrothermally altered MOR samples from midAtlantic Ridge are mainly hydroxylapatites $(55-81 \mathrm{~mol} \% \mathrm{OH})$ with the highest $\mathrm{Cl}$ contents $(11-36 \mathrm{~mol} \% \mathrm{Cl}$ ) in this study compared to apatites from fresh MORs and other rocks $(<61$ mol \% OH, $<28 \mathrm{~mol} \% \mathrm{Cl}$ ). Apatites from the Kiruna-type and alkalic porphyry $\mathrm{Cu}-\mathrm{Au}$ deposits and the barren (grano) diorites also show elevated $\mathrm{Cl}$ (up to $2.04 \mathrm{wt} \%$ ) relative to apatites from $\mathrm{Au}$-Co skarns, porphyry $\mathrm{Cu} \pm \mathrm{Mo} \pm \mathrm{Au}$, orogenic $\mathrm{Au}$, orogenic $\mathrm{Ni}-\mathrm{Cu}$ deposits, and some Wernecke IOCG breccias, all of which have detectable $\mathrm{Cl}$. The $\mathrm{Cl}$ contents are 
Table 3. LA-ICPMS Results for Quality Controls and Minimum Detection Limits

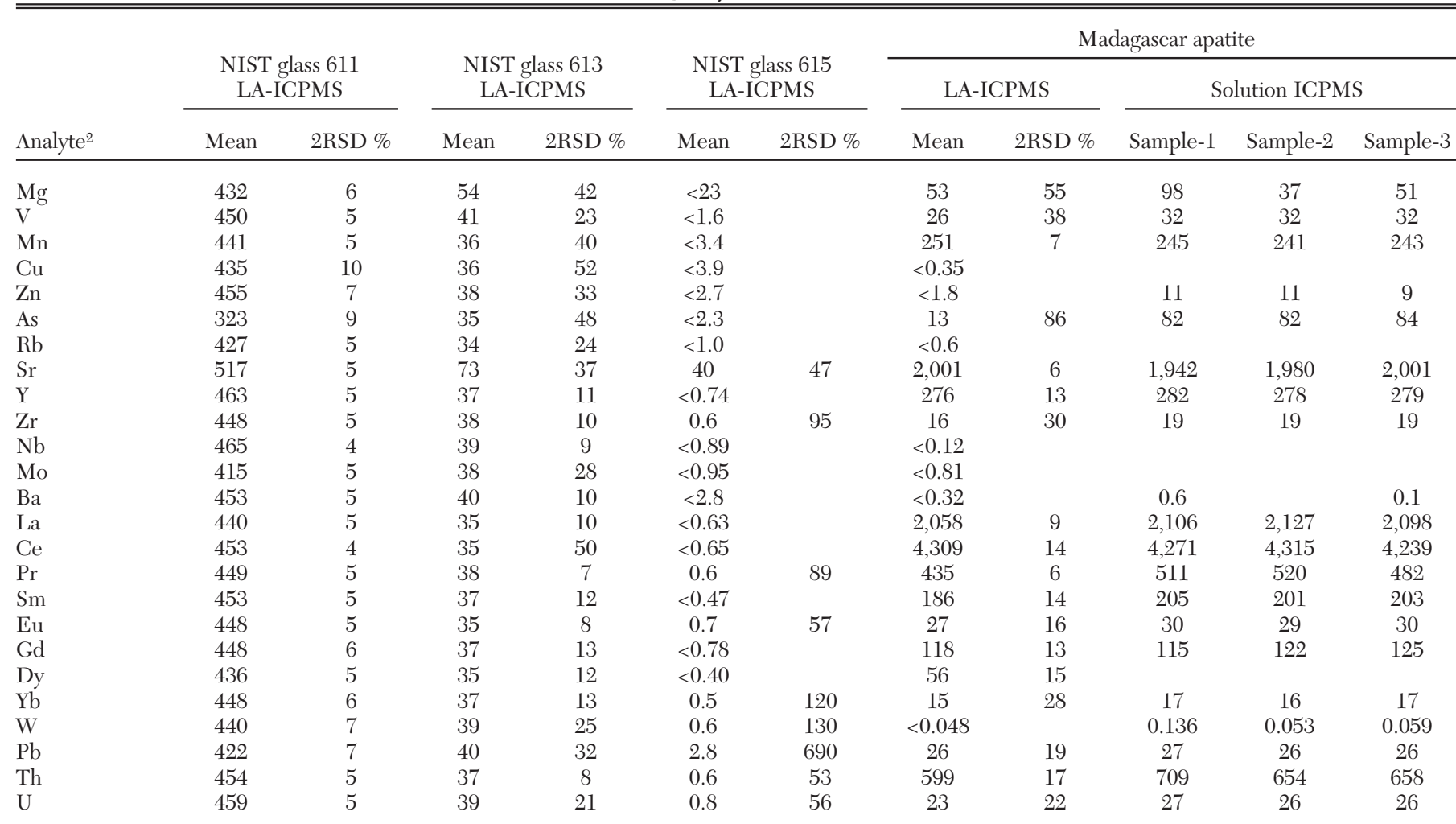

\begin{tabular}{|c|c|c|c|c|c|c|c|c|c|c|c|}
\hline \multirow[b]{2}{*}{ Analyte $^{2}$} & \multicolumn{2}{|c|}{$\begin{array}{c}\text { Durango apatite } \\
\text { LA-ICPMS }\end{array}$} & \multicolumn{3}{|c|}{ Solution ICPMS } & \multicolumn{3}{|c|}{$\begin{array}{c}\text { Reference apatite CTA-AC-1 } \\
\text { Solution ICPMS }\end{array}$} & \multicolumn{2}{|c|}{ Certified } & \multirow[t]{2}{*}{$\mathrm{MDL}^{1}$} \\
\hline & Mean & $2 \mathrm{RSD} \%$ & Sample-1 & Sample-2 & Sample-3 & Sample-1 & Sample-2 & Sample-3 & Mean & $\pm \mathrm{ppm}$ & \\
\hline $\mathrm{Mg}$ & 124 & 24 & 107 & 113 & 130 & 430 & 470 & 412 & 435 & & 6.9 \\
\hline$V^{0}$ & 43 & 36 & 54 & 50 & 49 & 97 & 102 & 99 & 104 & 10 & 1.6 \\
\hline $\mathrm{Mn}$ & 97 & 8 & 95 & 93 & 94 & 300 & 302 & 289 & 317 & 50 & 3.4 \\
\hline $\mathrm{Cu}$ & $<3.4$ & & & & & 48 & 60 & 46 & 54 & 5 & 0.35 \\
\hline $\mathrm{Zn}$ & $<2.7$ & & 5.9 & 12.2 & 10.2 & 38 & 33 & 26 & 38 & 8 & 1.8 \\
\hline As & 1242 & 22 & 1354 & 1217 & 1257 & 72 & 72 & 75 & & & 2.3 \\
\hline $\mathrm{Rb}$ & $<1.0$ & & & & & & & & & & 0.6 \\
\hline $\mathrm{Sr}$ & 513 & 6 & 520 & 477 & 510 & 23,006 & 21,563 & 22,588 & 20,000 & & 0.3 \\
\hline $\mathrm{Y}$ & 670 & 15 & 640 & 631 & 658 & 298 & 297 & 294 & 272 & 53 & 0.2 \\
\hline $\mathrm{Zr}$ & $<0.53$ & & 0.9 & 0.9 & 0.9 & 43 & 42 & 36 & 51 & & 0.05 \\
\hline $\mathrm{Nb}$ & $<0.12$ & & & & & & & & & & 0.12 \\
\hline Mo & $<0.81$ & & & & & & & & & & 0.81 \\
\hline $\mathrm{Ba}$ & $<1.4$ & & 2.4 & 1.8 & 4.0 & 852 & 849 & 834 & 767 & 79 & 0.32 \\
\hline $\mathrm{La}$ & 3,879 & 8 & 4,059 & 3,774 & 3,901 & 2,214 & 2,180 & 2,225 & 2,176 & 94 & 0.17 \\
\hline $\mathrm{Ce}$ & 4,773 & 8 & 4,810 & 4,481 & 4,659 & 3,453 & 3,384 & 3,474 & 3,326 & 175 & 0.06 \\
\hline $\operatorname{Pr}$ & 368 & 7 & 428 & 393 & 404 & 355 & 349 & 351 & & & 0.03 \\
\hline $\mathrm{Sm}$ & 162 & 14 & 167 & 168 & 169 & 165 & 165 & 164 & 162 & 24 & 0.13 \\
\hline $\mathrm{Eu}$ & 16 & 11 & 16 & 17 & 17 & 45.6 & 46.1 & 45.0 & 46.7 & 1.3 & 0.01 \\
\hline Gd & 149 & 14 & 154 & 151 & 155 & 131 & 130 & 128 & 124 & 23 & 0.1 \\
\hline Dy & 107 & 15 & & & & & & & & & 0.02 \\
\hline $\mathrm{Yb}$ & 39 & 15 & 40 & 40 & 41 & 11 & 11 & 10 & 11 & 2 & 0.01 \\
\hline W & $<0.017$ & & 0.065 & 0.047 & 0.074 & 0.1 & 0.1 & 0.1 & & & 0.01 \\
\hline $\mathrm{Pb}$ & $<0.9$ & & 0.8 & 0.7 & 0.7 & 3.3 & 2.5 & 3.2 & & & 0.07 \\
\hline Th & 222 & 19 & 281 & 269 & 250 & 22.0 & 21.9 & 21.6 & 21.8 & 2.1 & 0.01 \\
\hline $\mathrm{U}$ & 10 & 19 & 12 & 11 & 11 & 4.0 & 3.9 & 3.9 & 4.4 & 0.9 & 0.01 \\
\hline
\end{tabular}

Notes: Iron concentrations, which were analyzed by both LA-ICPMS and EMPA, are not listed due to poor detection limits (from 150 to 2,200 ppm and $\sim 0.14$ wt \%, respectively); consequently, only 44 analyses returned Fe concentrations above the detection limits; these data are not discussed here but are given in the Appendix Table 4

${ }^{1}$ Minimum detection limit

${ }^{2}$ All units are parts per million (ppm) 


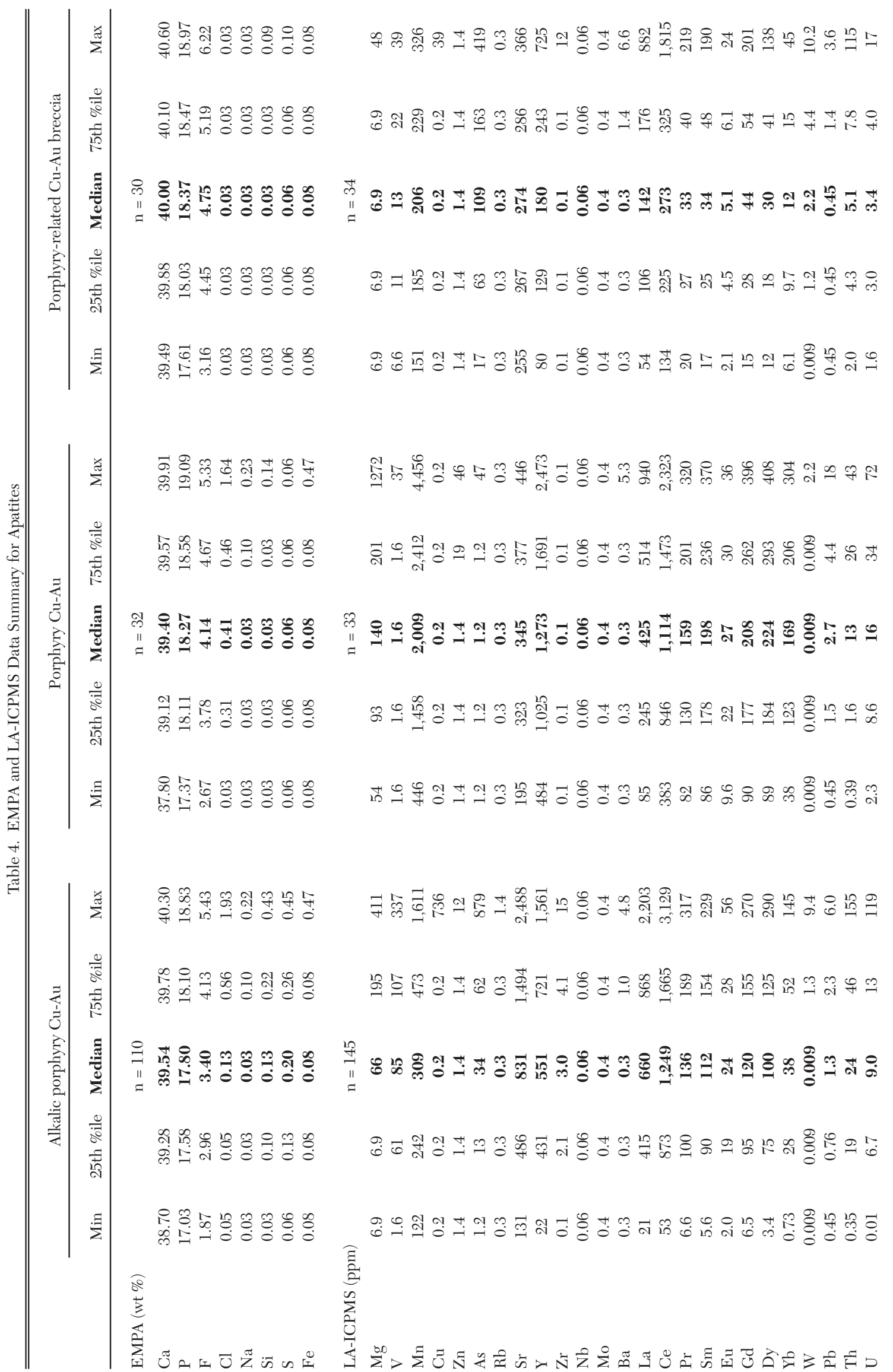




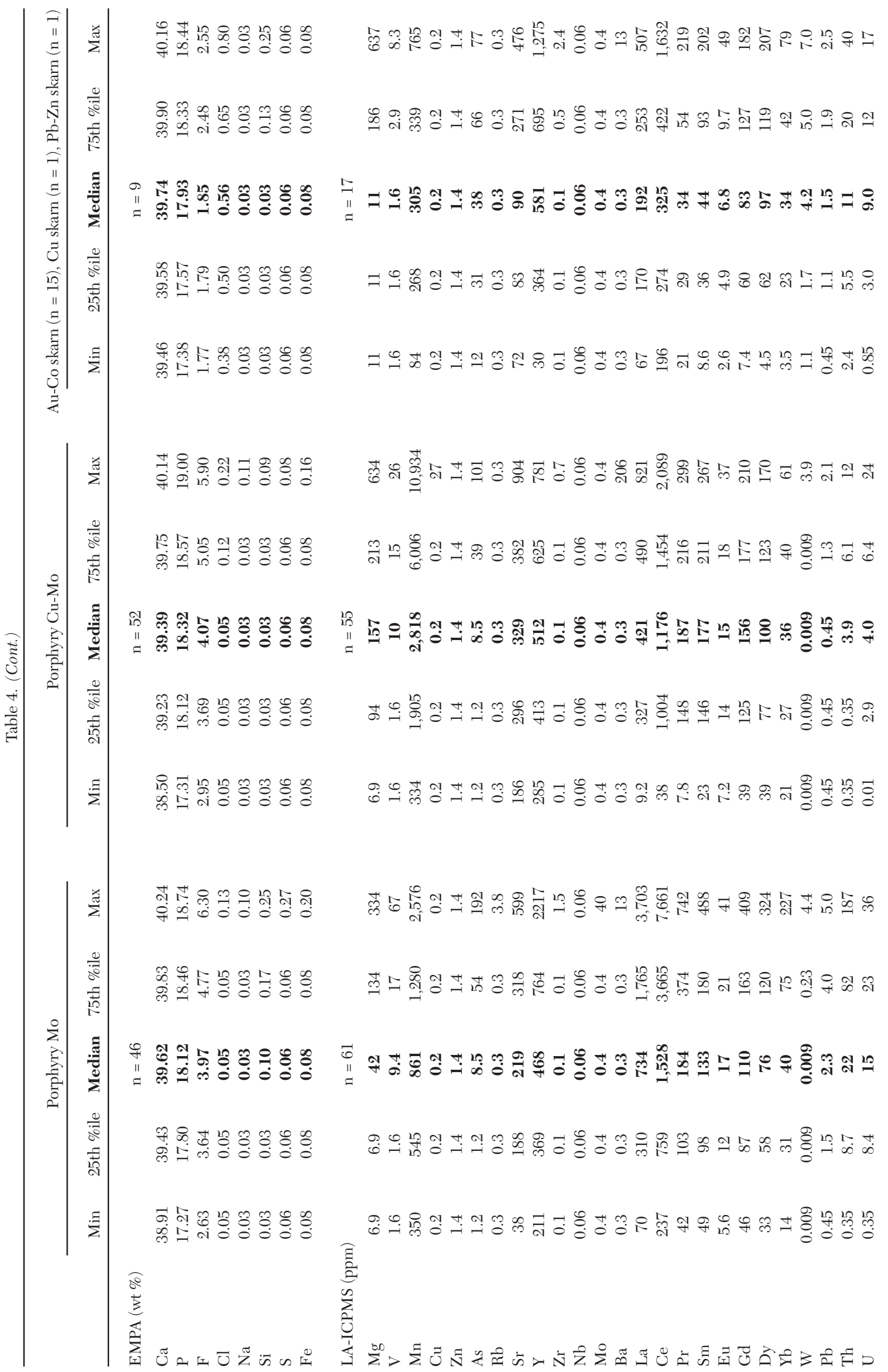




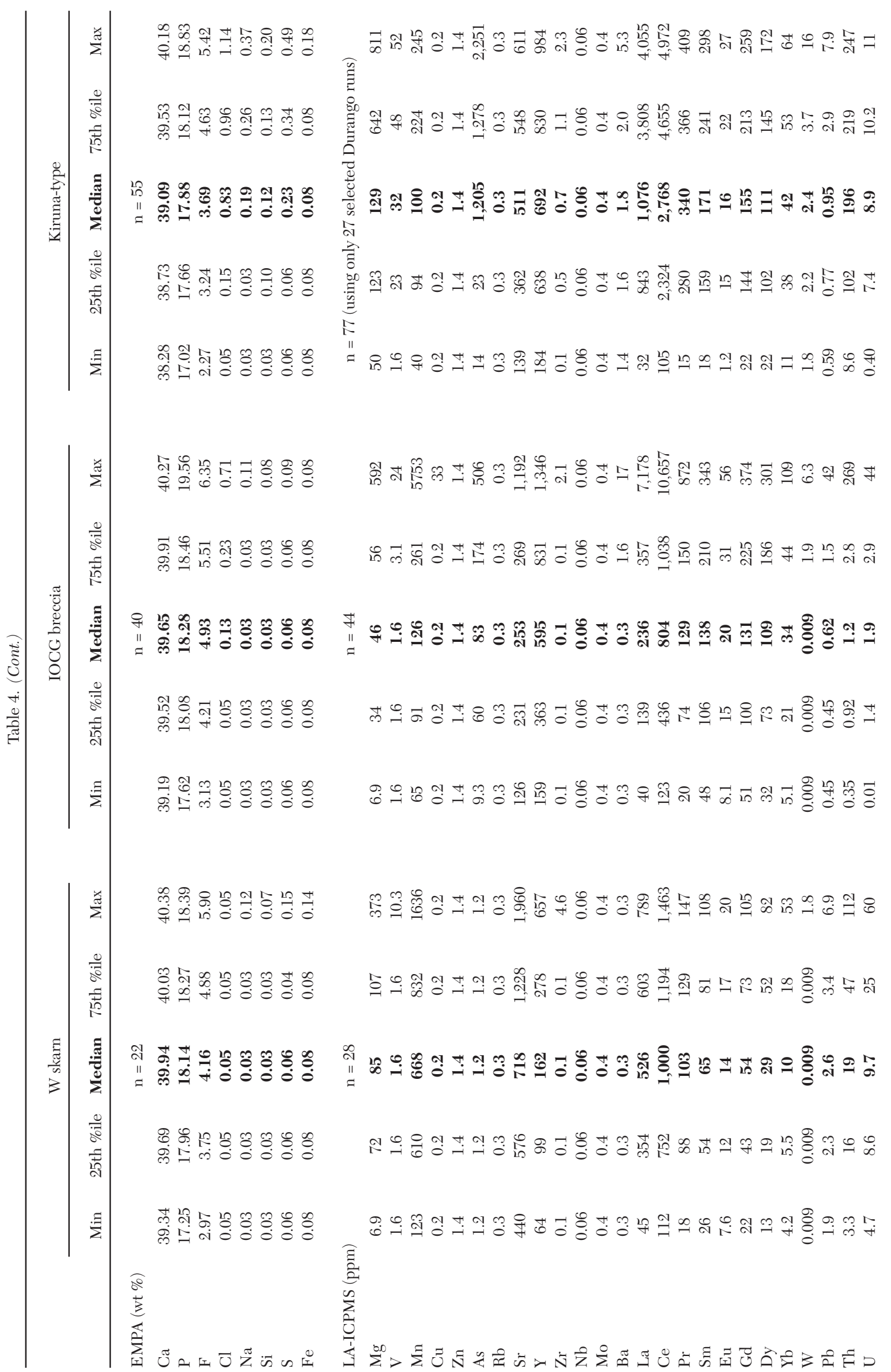




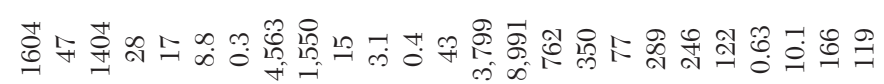

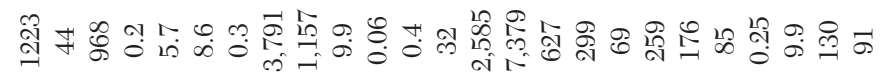

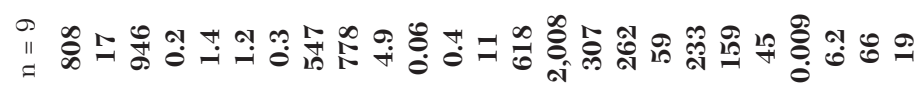

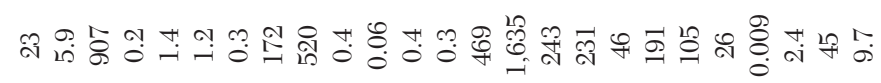

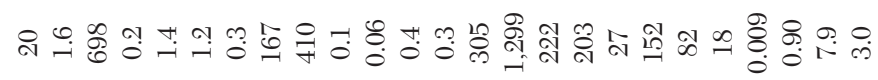

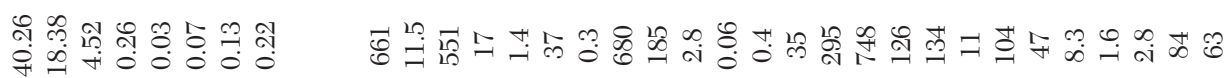

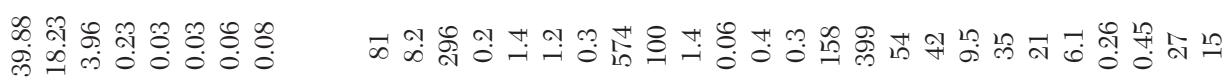

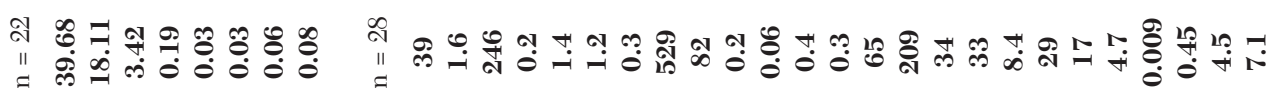

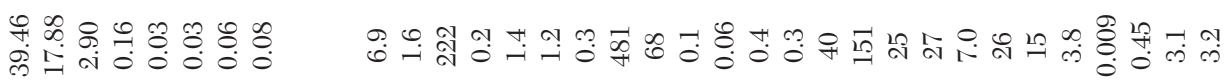

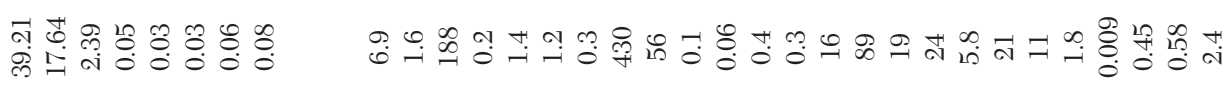

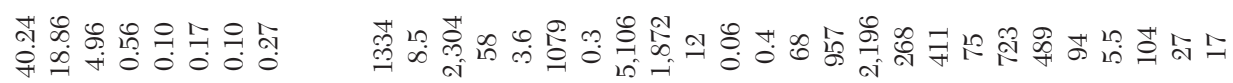

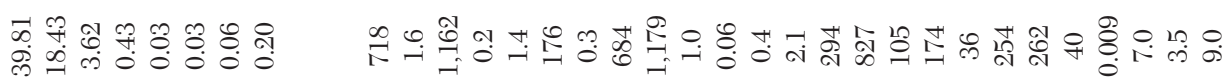
吾

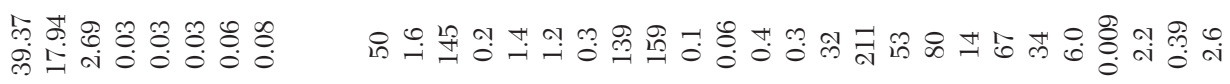

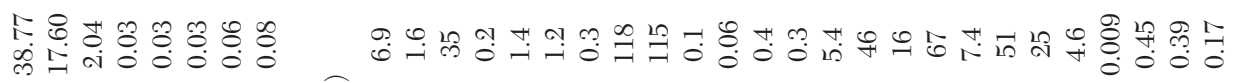

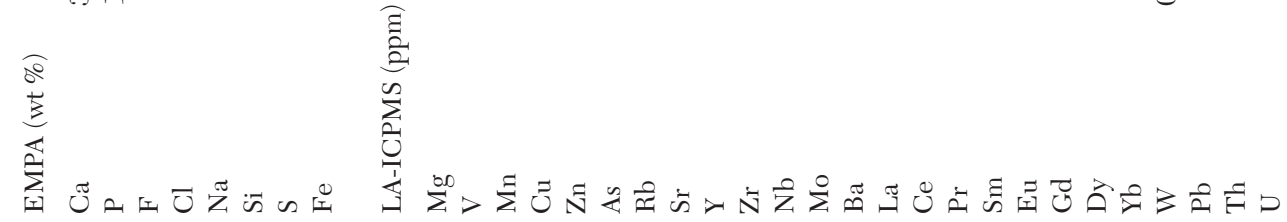




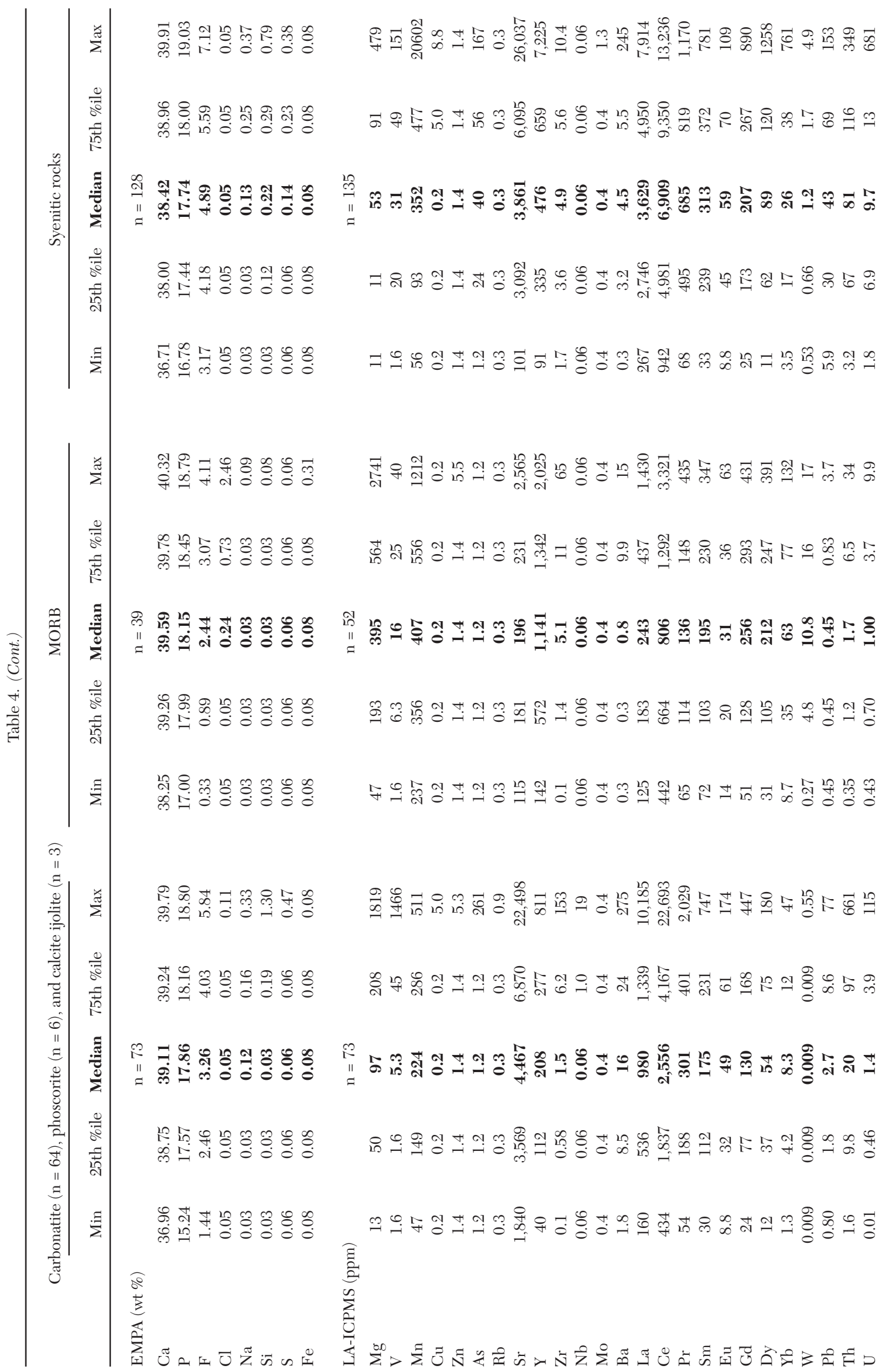




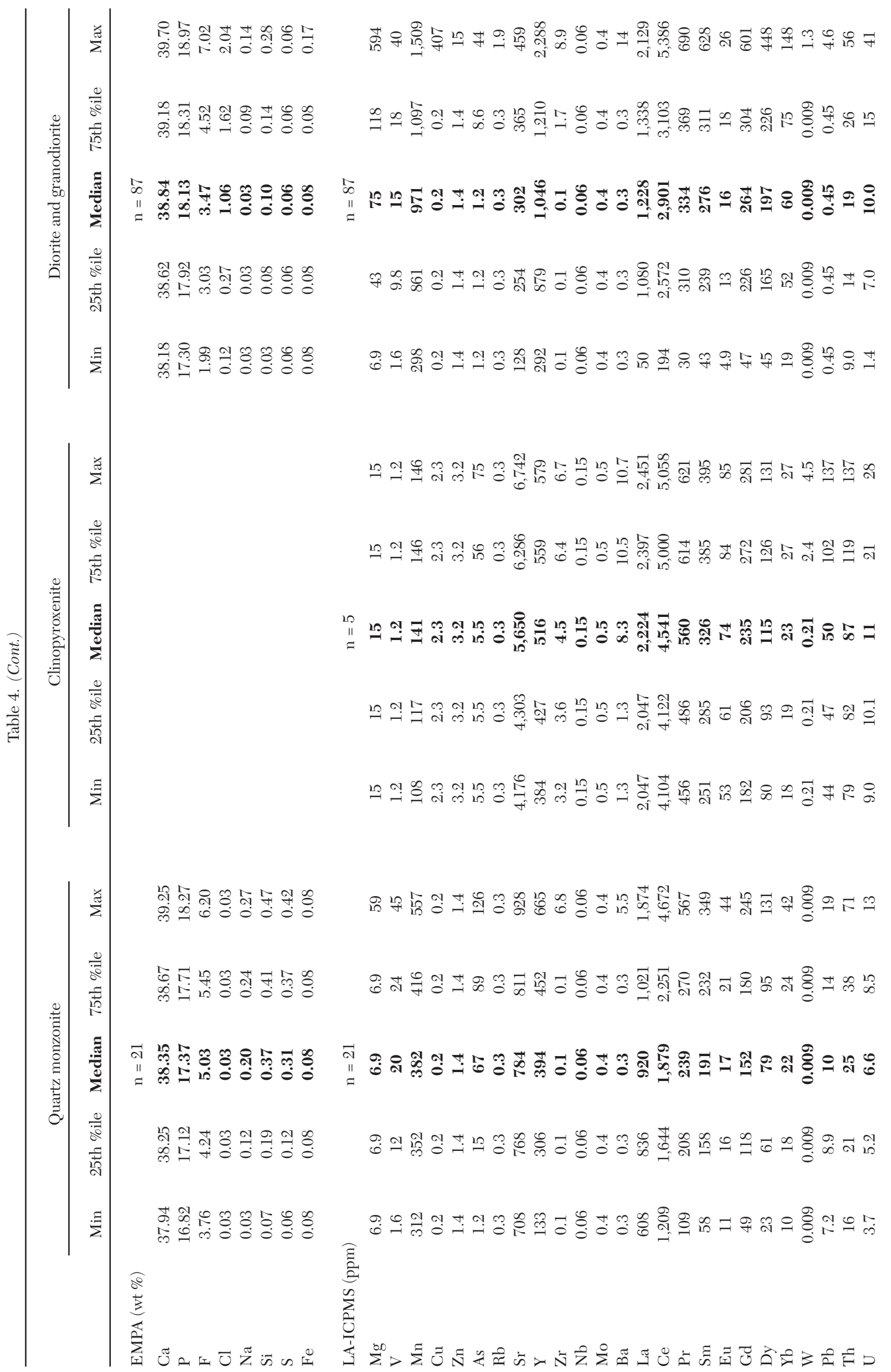




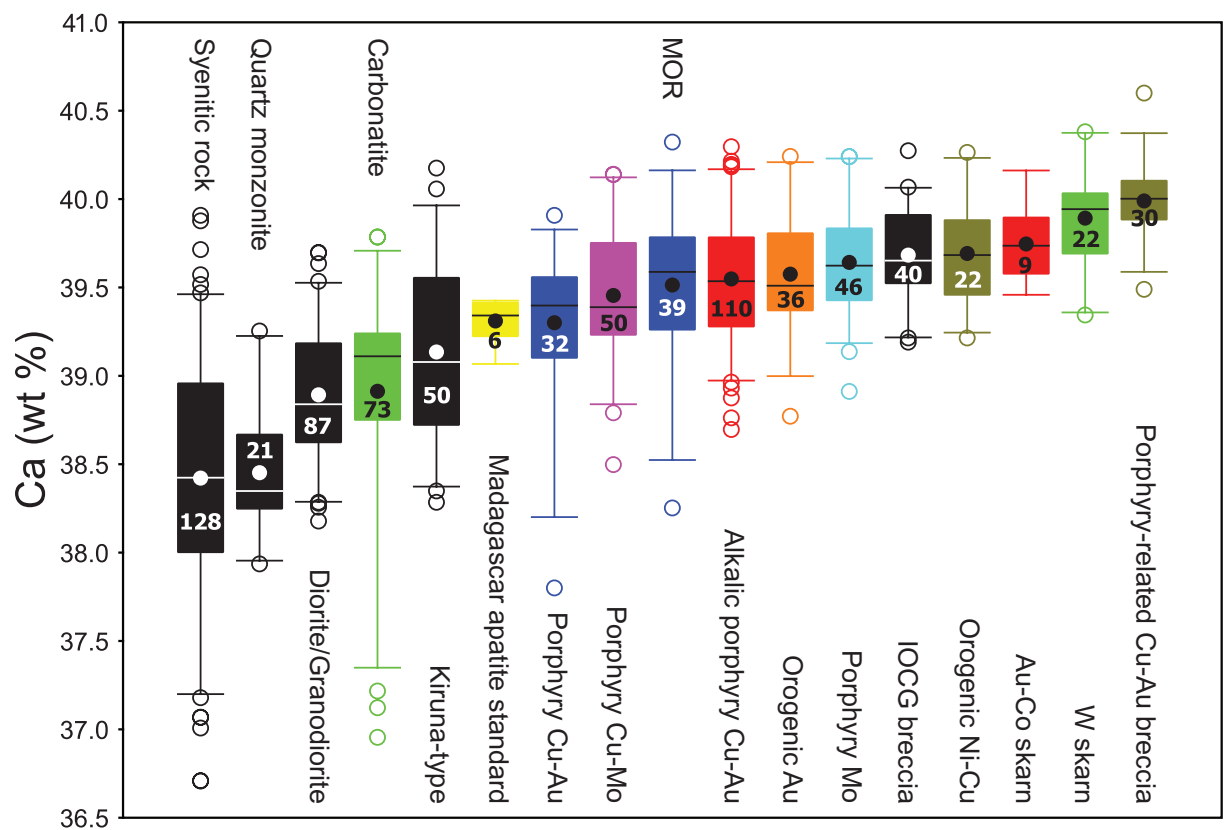

Fig. 2. Box plots showing Ca contents of apatites for each group. Line = median value; solid dot $=$ mean value; box $=$ interquartile range (25th-75th percentile); whiskers: 5 th and 95 th percentiles; open circle: $<5$ th and $>95$ th percentile values. Carbonatite group includes apatite data from carbonatites and related phoscorites and ijolite.

(a)

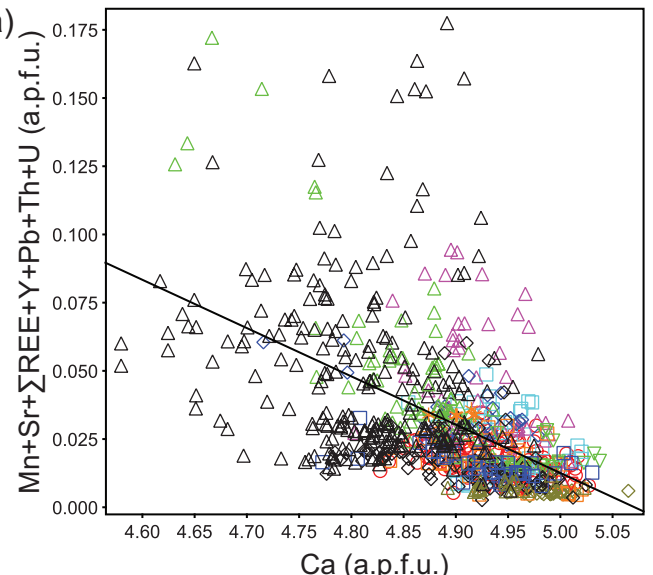

(b)

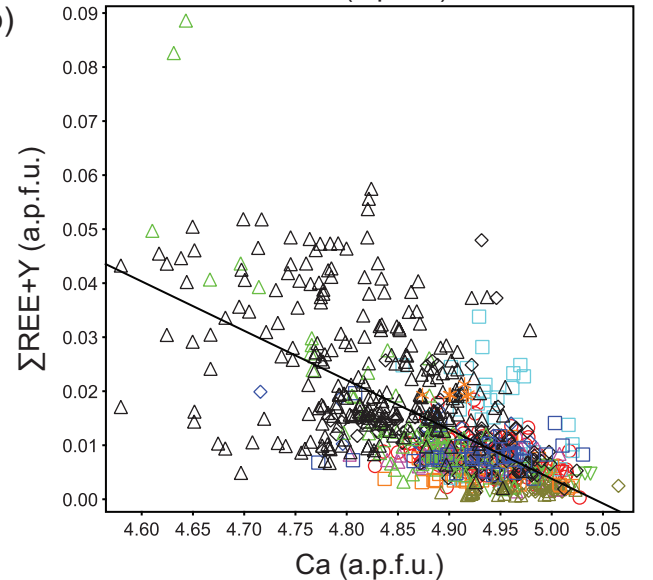

(c)

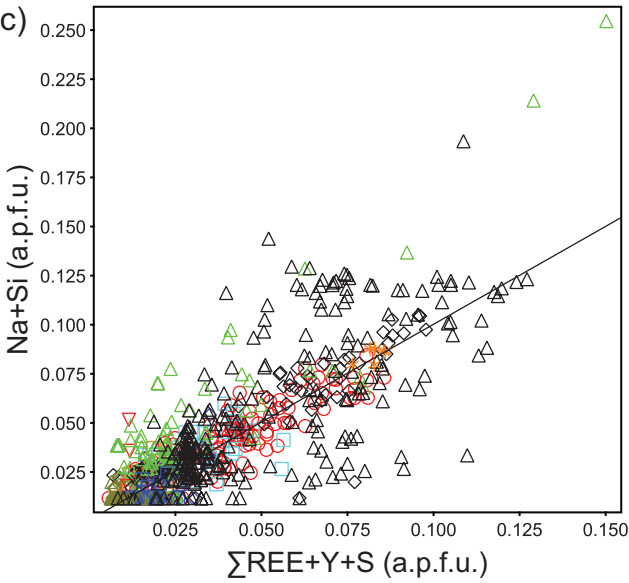

$\triangle$ Carbonatites, phoscorites, $\bigcirc$ Alkalic porphyry Cu-Au and associated ijolites

MOR

$\diamond$ IOCG and Kiruna-type

$\diamond$ Porphyry Cu-Au

Orogenic Au

$\triangle$ Porphyry Cu-Mo

Orogenic $\mathrm{Ni}-\mathrm{Cu}$

Porphyry Mo

$\diamond$ Porphyry-related Cu-Au breccia

Epithermal Au-Ag

$\nabla$ Au-Co, $\mathrm{Cu}$, and

$\mathrm{Pb}-\mathrm{Zn}$ skarns

$\triangle$ Unmineralized rocks

* Madagascar apatite standard

Fig. 3. Scatterplots for apatite compositions calculated to apfu on the basis of oxygen atoms. a) Ca vs. $(\mathrm{Mn}+\mathrm{Sr}+\Sigma \mathrm{REE}+\mathrm{Y}$ $+\mathrm{Pb}+\mathrm{Th}+\mathrm{U}) ; \Sigma \mathrm{REE}=\mathrm{La}+\mathrm{Ce}+\mathrm{Pr}+\mathrm{Sm}+\mathrm{Eu}+\mathrm{Gd}+\mathrm{Dy}+\mathrm{Yb}$. b) Ca vs. $(\Sigma \mathrm{REE}+\mathrm{Y}) \cdot \mathrm{c})(\Sigma \mathrm{REE}+\mathrm{Y}+\mathrm{S})$ vs. $(\mathrm{Na}+\mathrm{Si})$. Least squares regression lines through the data are shown in Figure $3 \mathrm{a}-\mathrm{b}$, and the $\mathrm{X}=\mathrm{Y}$ line is shown in Figure 3c. 
rarely above the detection limit $(0.07 \mathrm{wt} \%)$ in apatites from porphyry Mo and W skarn deposits, carbonatites, and other barren rocks (Table 4). Chlorine in apatites can be related to the accommodation of LREE (Pan and Fleet, 2002), and is also a petrogenetic indicator of magma fractionation or the involvement of saline fluids (Barton and Johnson, 1996; O'Reilly and Griffin, 2000; Piccoli and Candela, 2002; Oliver et al., 2004).

\section{Magnesium, manganese, strontium, barium, and lead}

Magnesium concentrations in apatites range from below the detection limit (7-30 ppm) to 2,741 ppm. Mg concentrations rarely exceed the detection limit in apatites from the $\mathrm{Au}-\mathrm{Co}$ skarn and porphyry-related $\mathrm{Cu}-\mathrm{Au}$ breccia deposits and syenitic rocks. Apatites from MORs have the highest $\mathrm{Mg}$ contents in this study (47-2,741 ppm). Apatites from epithermal, Kiruna-type, and orogenic Au deposits, and from carbonatites, also have high but variable Mg concentrations (Fig. 4).

Manganese contents of the apatites studied are between 35 and 2,576 ppm except for the porphyry Cu-Mo and porphyry $\mathrm{Cu}-\mathrm{Au}$ groups, some apatites from Wernecke IOCG breccia, and a single analysis from a metamorphosed alkali-feldspar syenite from the Omineca belt, British Columbia. Apatites from these rocks have the highest Mn concentrations in this

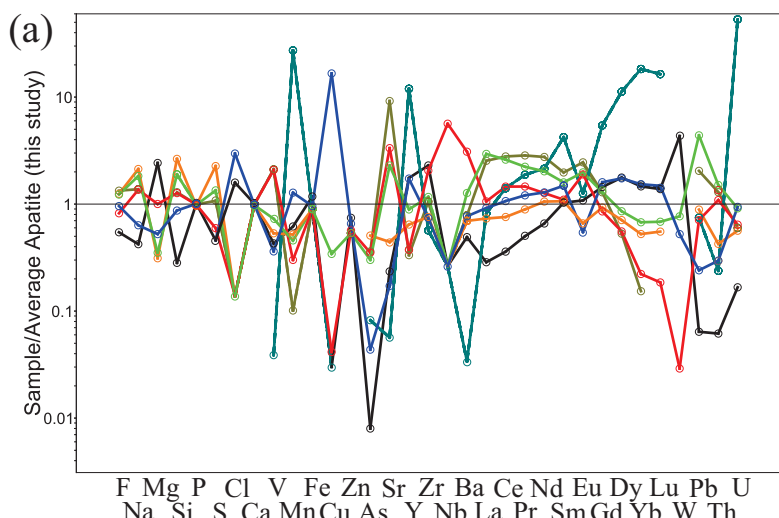

Mid-ocean ridge gabbro (4 localities; $\mathrm{n}=7 / 52$ )

Abitibi monzonite (McElroy pluton, $\mathrm{n}=1 / 21$ )

$\bigcirc$ Abitibi pyroxenite and syenites ( 3 plutons, $n=6 / 118)$

Abitibi hornblende syenite (Otto stock, $\mathrm{n}=1 / 21$ )

$\bigcirc$ Vancouver Island diorites and granodiorites ( 2 plutons, $n=4 / 87$ )

$\bigcirc$ Omineca metamorphosed alkali-feldspar syenite (Blu Starr, $\mathrm{n}=1 / 1$ )

Worldwide carbonatites (29 plutons, $\mathrm{n}=31 / 73$ )

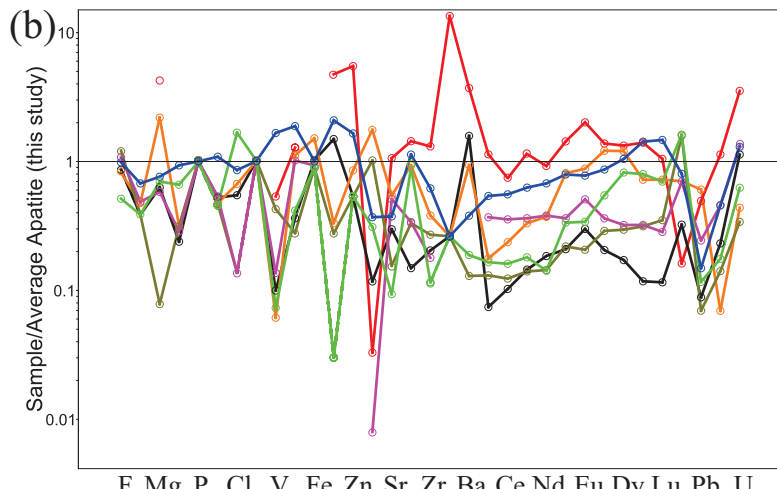

Epithermal Au-Ag (2 deposits, $\mathrm{n}=3 / 9)$

O Orogenic Ni-Cu (Jason, $\mathrm{n}=1 / 28$ )

Orogenic $\mathrm{Au}$ (4 deposits, $\mathrm{n}=5 / 45$ )

O Porphyry-related $\mathrm{Cu}-\mathrm{Au}$ breccia (Willa, $n=1 / 34)$

O W skarn ( 2 deposits, $\mathrm{n}=2 / 28)$

O Au-Co, $\mathrm{Cu}$, and $\mathrm{Pb}-\mathrm{Zn}$ skarns (4 deposits, $\mathrm{n}=5 / 17$ )

O Porphyry $\mathrm{Cu} \pm \mathrm{Au} \pm$ Mo and porphyry Mo (12 deposits, $n=18 / 294)$

(c)

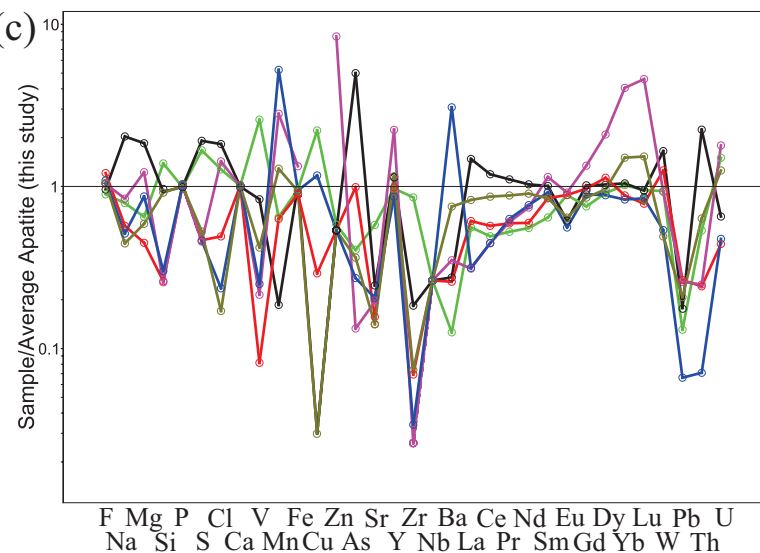

Alkalic porphyry $\mathrm{Cu}-\mathrm{Au}$ (3 deposits, $\mathrm{n}=9 / 145)$

O Porphyry $\mathrm{Cu}-\mathrm{Au}$ (Kemess South, $\mathrm{n}=2 / 33$ )

O Porphyry $\mathrm{Cu}-\mathrm{Mo}$ (4 deposits, $\mathrm{n}=4 / 55$ )

Porphyry Mo (4 deposits, $n=4 / 61$ )

O Kiruna-type ( 3 deposits, $n=7 / 77$ )

O IOCG breccia (Wernecke, $n=4 / 44$ )

Fig. 4. Spider diagrams for median apatite compositions normalized to the average apatite in this study. Numerator indicates number of rock samples and denominator number of analyses (Table 2). a) Unmineralized rocks. b) Mineral deposits except Kiruna-type and IOCG. c) Porphyry, Kiruna-type, and IOCG deposits. 
study, ranging between 334 and 10,934 ppm for the porphyry deposits and some IOCG breccias, and up to 20,602 ppm in the Omineca syenite. Apatites from the Au-Co skarn, Kirunatype, orogenic $\mathrm{Ni}-\mathrm{Cu}$, and porphyry-related $\mathrm{Cu}-\mathrm{Au}$ breccia deposits, carbonatites, and unmineralized clinopyroxenite, quartz monzonite, and syenitic rocks from the Abitibi belt of the Canadian Shield have relatively low Mn contents (40-620 $\mathrm{ppm})$. Although large variations exist between the different apatite groups, Mn concentrations have fairly restricted ranges within each deposit type (Table 4; Fig. 4). This suggests that Mn, a redox-sensitive element (Miles et al., 2014), is particularly useful in discriminating apatites formed in different geologic settings.

Strontium concentrations show large variations, from 38 to 26,037 ppm, across all analyzed apatites. Apatites from the porphyry Mo and Au-Co skarn deposits and the Omineca alkalifeldspar syenite have the lowest $\mathrm{Sr}$ contents (38-599 ppm), whereas apatites from carbonatites and unmineralized clinopyroxenite and syenitic rocks from Abitibi have the highest $\mathrm{Sr}$ contents (1,744-26,037 ppm) in this study. Apatites from the orogenic $\mathrm{Au}$, epithermal $\mathrm{Au}-\mathrm{Ag}$, and alkalic porphyry $\mathrm{Cu}-\mathrm{Au}$ deposits are distinct from other groups and show a wide range of $\mathrm{Sr}$ contents (118-5,106 ppm). Apatites from other groups have Sr contents between 115 and 2,565 ppm. Similar to Mn, the large variations of $\mathrm{Sr}$ contents between the different apatite groups, coupled with the more restricted within-group variations, suggest that the Sr content of apatite will be useful in discriminating between different deposits and rock types (Table 4; Fig. 4).

Barium is rarely detectable in the apatite groups. The highest Ba contents characterize apatites from carbonatites (1.8$275 \mathrm{ppm}$ ), epithermal Au-Ag deposits (<4.3-43 ppm), and a grain from the Abitibi alkali-feldspar syenite (245 ppm). Apatites are generally $\mathrm{Ba}$ poor, although the orogenic $\mathrm{Ni}-\mathrm{Cu}$, orogenic $\mathrm{Au}$, and porphyry $\mathrm{Cu}-\mathrm{Mo}$ deposits possess $\mathrm{Ba}$ contents of up to $206 \mathrm{ppm}$. All other apatites contain $<20 \mathrm{ppm} \mathrm{Ba.}$

Apatite $\mathrm{Pb}$ concentrations range from $<1$ to $153 \mathrm{ppm}$, with the highest values in apatites from both mineralized and unmineralized rocks of the Neoarchean Abitibi belt. Unmineralized rocks contain 6 to $153 \mathrm{ppm} \mathrm{Pb}$ similar to orogenic Au from the Kirkland Lake (up to $104 \mathrm{ppm}$ ) and carbonatites from Lac Shortt (up to $77 \mathrm{ppm}$ ). Apatites from the Wernecke IOCG breccia also contain up to $42 \mathrm{ppm} \mathrm{Pb}$. All other analyzed apatites contain $<20 \mathrm{ppm} \mathrm{Pb}$.

\section{Sodium, silicon, and sulfur}

The Na content of apatites varies from $<0.07$ to $0.37 \mathrm{wt} \%$, with the largest ranges of concentrations in unmineralized rocks from the Abitibi belt, carbonatites, Kiruna-type, alkalic porphyry $\mathrm{Cu}-\mathrm{Au}$, and porphyry $\mathrm{Cu}-\mathrm{Au}$ deposits. The $\mathrm{Na}$ contents of apatites from other samples are $<0.15$ wt $\%$ and rarely exceed the detection limit.

Apatites from carbonatites possess the widest range of $\mathrm{Si}$ contents from $<0.05$ to 1.30 wt \%. Measurable Si contents also occur in the majority of apatite grains from unmineralized rocks (up to $0.79 \mathrm{wt} \%$, and the alkalic porphyry $\mathrm{Cu}-\mathrm{Au}$, porphyry $\mathrm{Mo}, \mathrm{Au}-\mathrm{Co}$ skarn, and Kiruna-type deposits (up to $0.43 \mathrm{wt} \%)$. The Si content of other apatites rarely exceeds the detection limit $(0.05-0.08 \mathrm{wt} \%)$, and are always $<0.20 \mathrm{wt} \%$ Si.
Apatite S contents range from $<0.07$ to $0.49 \mathrm{wt} \%$, with most concentrations above the detection limit. The largest $\mathrm{S}$ ranges are from the Kiruna-type and alkali porphyry $\mathrm{Cu}-\mathrm{Au}$ deposits, and the unmineralized rocks from the Abitibi belt. Relatively high S contents $(0.30-0.47$ wt \%) are measured in apatites from one carbonatite complex (Magnet Cove). Other apatites rarely show detectable $\mathrm{S}$ concentrations $(<0.3 \mathrm{wt} \%)$.

Positive correlation of the $\mathrm{Si}$ and $\mathrm{Na}$ contents with the $\mathrm{S}$ contents for some of the apatite groups in this study (e.g., alkalic porphyry $\mathrm{Cu}-\mathrm{Au}$ and Kiruna-type deposits, and most of the syenitic rocks) suggests the coupled substitutions described by the equations (6) and (7). High concentrations of $\mathrm{Na}$ and S in apatite can indicate sodic alteration and $\mathrm{SO}_{3}$ in the parent magma or fluid, respectively (Peng et al., 1997; Streck and Dilles, 1998; Oliver et al., 2004).

\section{REE and yttrium}

Apatites from the epithermal Au-Ag deposits and most of the unmineralized rocks, carbonatites, and the Kiruna-type deposits show the strongest enrichment in light REE (LREE) in this study. The sum of selected LREE ( $\Sigma$ LREE $=\mathrm{La}+$ $\mathrm{Ce}+\mathrm{Pr}+\mathrm{Sm}+\mathrm{Eu}$ ) range mostly from 835 to $35,534 \mathrm{ppm}$. Some apatites from the Wernecke IOCG breccia deposit also have very high $\Sigma$ LREE values (up to 19,050 ppm). Apatites from the orogenic Ni-Cu and most of the samples from $\mathrm{Au}-\mathrm{Co}$ skarn, orogenic $\mathrm{Au}$, and porphyry-related $\mathrm{Cu}-\mathrm{Au}$ breccia deposits show much lower $\Sigma$ LREE than the majority of the studied apatites (158-1,318 ppm). The lowest $\Sigma$ LREE values of $\sim 90 \mathrm{ppm}$ are from the alkalic porphyry $\mathrm{Cu}-\mathrm{Au}$ and porphyry Cu-Mo samples, although the majority of apatites from these deposits are moderately enriched in LREE compared with other samples.

The distribution of heavy REE (HREE) (Gd, Dy, Yb, and $\mathrm{Lu}$ ) is nearly identical to that of $\mathrm{Y}$ and differs from that of the LREE. Apatites from alkali-feldspar syenite of the Omineca belt have the highest sum of selected HREE ( $\mathrm{H}$ HREE $=\mathrm{Gd}+\mathrm{Dy}+\mathrm{Yb})$ and $\mathrm{Y}$ contents of 2,910 and 7,225 ppm, respectively, in this study. Relatively high $\Sigma$ HREE and Y concentrations are found in apatites from unmineralized diorites and granodiorites (251 to $1,175 \mathrm{ppm}$ ), and porphyry $\mathrm{Cu}-\mathrm{Au}$, epithermal $\mathrm{Au}-\mathrm{Ag}$, and most of the Kiruna-type deposits and MORs (392-2,473 ppm). The lowest $\Sigma$ HREE contents (33$385 \mathrm{ppm}$ ) and Y contents (56-725 ppm) characterize apatites from the orogenic $\mathrm{Ni}-\mathrm{Cu}$, porphyry-related $\mathrm{Cu}-\mathrm{Au}$ breccia, and $\mathrm{W}$ skarn deposits. Most apatites from carbonatites also have $<250$ ppm $\Sigma$ HREE and $<280$ ppm Y.

Trivalent rare earth elements and $\mathrm{Y}^{3+}$ substitute for $\mathrm{Ca}^{2+}$ in apatite with the main charge compensators including $\mathrm{Na}^{+}$and $\mathrm{SiO}_{4}^{4-}$ (eq. 1-4). $\mathrm{SO}_{4}^{2-}$ in apatites also correlates with $\mathrm{Na}^{+}$and $\mathrm{SiO}_{4}^{4-}$ (eq. 6, 7). The $\Sigma \mathrm{REE}+\mathrm{Y}(\Sigma \mathrm{REE}+\mathrm{Y}=\mathrm{La}+\mathrm{Ce}+\mathrm{Pr}+$ $\mathrm{Sm}+\mathrm{Eu}+\mathrm{Gd}+\mathrm{Dy}+\mathrm{Yb}+\mathrm{Y})$ contents in this study generally show a negative relation with Ca content in all apatites (Fig. $3 \mathrm{~b})$, and the $\Sigma \mathrm{REE}+\mathrm{Y}+\mathrm{S}$ have a positive relation with $\mathrm{Na}$ $+\mathrm{Si}$ (Fig. 3c).

The behavior of $\mathrm{Ce}$ and $\mathrm{Eu}$ can differ from that of the adjacent REEs due to redox sensitivity. The Ce anomalies $\left(\mathrm{Ce} / \mathrm{Ce}^{*}=\mathrm{Ce}_{\mathrm{CN}} /\left(\mathrm{La}_{\mathrm{CN}} \cdot \mathrm{Pr}_{\mathrm{CN}}\right)^{-0.5}\right.$; Lodders, 2010) are mostly between 0.9 and 1.4 in the studied apatites, but can be as high as 1.7, as indicated by the data from carbonatites (Figs. 5, 6). Apatites from carbonatites and epithermal deposits generally 

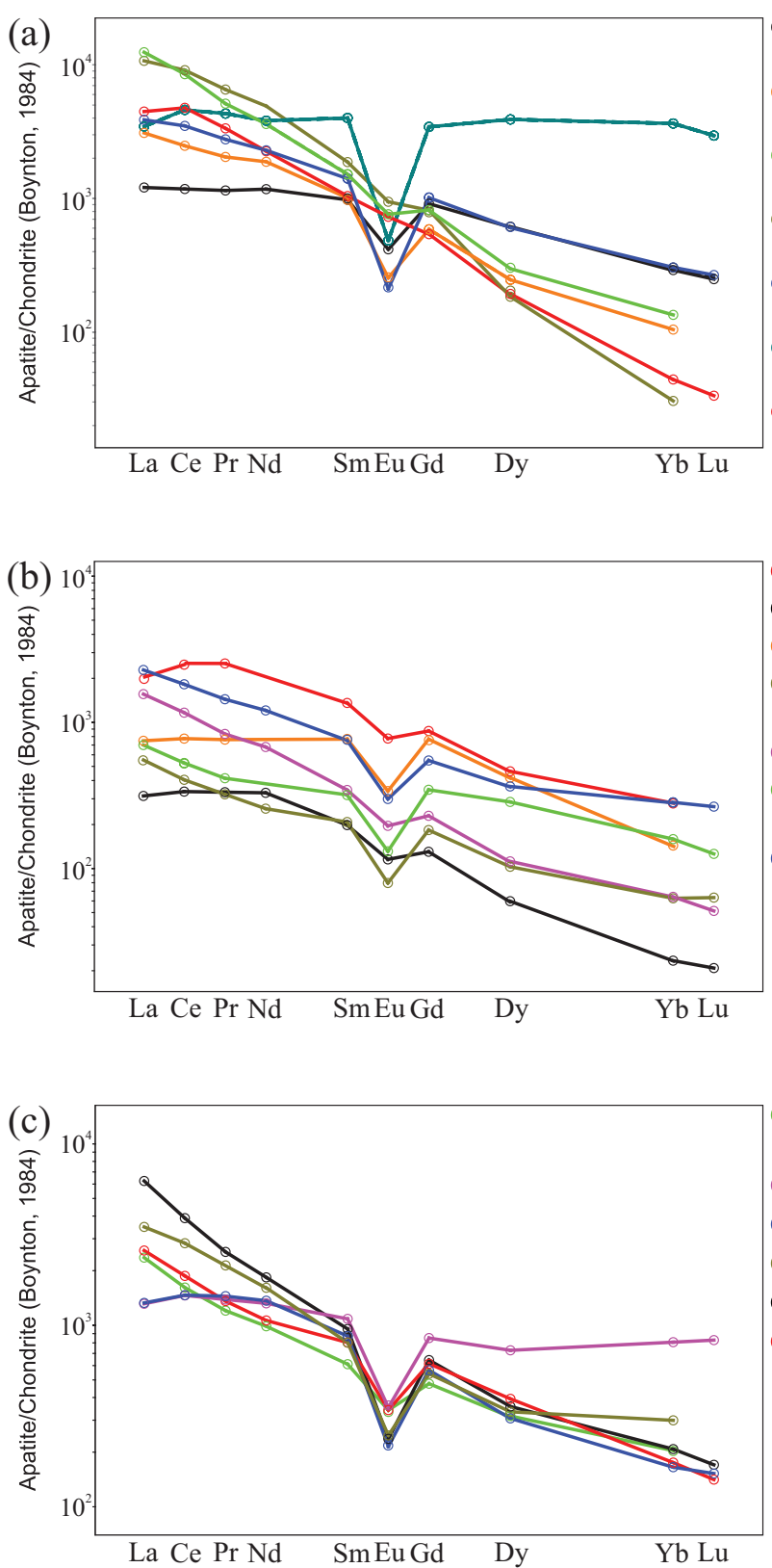

Mid-ocean ridge gabbro (4 localities; $\mathrm{n}=7 / 52$ )

Abitibi monzonite (McElroy pluton, $\mathrm{n}=1 / 21$ )

Abitibi pyroxenite and syenites (3 plutons, $n=6 / 118)$

Abitibi hornblende syenite (Otto stock, $n=1 / 21$ )

O Vancouver Island diorites and granodiorites ( 2 plutons, $n=4 / 87$ )

$\bigcirc$ Omineca metamorphosed alkali-feldspar syenite (Blu Starr, $\mathrm{n}=1 / 1$ )

Worldwide carbonatites (29 plutons, $\mathrm{n}=31 / 73$ )

Epithermal Au-Ag (2 deposits, $\mathrm{n}=3 / 9$ )

O Orogenic Ni-Cu (Jason, $\mathrm{n}=1 / 28$ )

Orogenic $\mathrm{Au}$ (4 deposits, $\mathrm{n}=5 / 45$ )

O Porphyry-related $\mathrm{Cu}-\mathrm{Au}$ breccia (Willa, $\mathrm{n}=1 / 34$ )

W skarn ( 2 deposits, $\mathrm{n}=2 / 28)$

O $\mathrm{Au}-\mathrm{Co}, \mathrm{Cu}$, and $\mathrm{Pb}-\mathrm{Zn}$ skarns (4 deposits, $\mathrm{n}=5 / 17$ )

O Porphyry $\mathrm{Cu} \pm \mathrm{Au} \pm \mathrm{Mo}$ and porphyry Mo (12 deposits, $n=18 / 294$ )

Alkalic porphyry $\mathrm{Cu}-\mathrm{Au}$ (3 deposits, $\mathrm{n}=9 / 145)$

O Porphyry $\mathrm{Cu}-\mathrm{Au}$ (Kemess South, $\mathrm{n}=2 / 33$ )

O Porphyry $\mathrm{Cu}-\mathrm{Mo}$ (4 deposits, $\mathrm{n}=4 / 55$ )

O Porphyry Mo (4 deposits, $n=4 / 61$ )

O Kiruna-type (3 deposits, $\mathrm{n}=7 / 77$ )

O IOCG breccia (Wernecke, $n=4 / 44$ )

Fig. 5. Chondrite-normalized REE plots for median apatite compositions. Numerator indicates number of rock samples and denominator number of analyses (Table 2). a) Unmineralized rocks. b) Mineral deposits except IOCG and Kiruna-type IOA. c) Porphyry, Kiruna-type, and IOCG deposits.

have positive $\mathrm{Ce}$ anomalies $\left(\mathrm{Ce} / \mathrm{Ce}^{*}>1.0\right)$, and some apatites from the alkalic porphyry $\mathrm{Cu}-\mathrm{Au}, \mathrm{Au}-\mathrm{Co}$ skarn, and porphyryrelated $\mathrm{Cu}-\mathrm{Au}$ breccia groups may have weak negative $\mathrm{Ce}$ anomalies $\left(\mathrm{Ce} / \mathrm{Ce}^{*}=0.87-1.12\right)$. The rest of the studied apatites generally lack Ce anomalies (Figs. 5, 6).

The $\mathrm{Eu}$ anomalies $\left(\mathrm{Eu} / \mathrm{Eu}^{*}=\mathrm{Eu}_{\mathrm{CN}} /\left(\mathrm{Sm}_{\mathrm{CN}} \cdot \mathrm{Gd}_{\mathrm{CN}}\right)^{-0.5}\right.$; Lodders, 2010) in magmatic apatites generally track the role of feldspar in the generation and fractionation of the melt prior to apatite crystallization. The apatites in this study have $\mathrm{Eu} / \mathrm{Eu}^{*}$ values ranging from 0.08 to 1.54. Apatites from carbonatites generally lack Eu anomalies $\left(\mathrm{Eu} / \mathrm{Eu}^{*}=0.85-1.16\right.$, median $=0.98)$, whereas most of the apatites from other groups have negative $\mathrm{Eu}$ anomalies of variable magnitude.
Apatites from the Kiruna-type deposits and the unmineralized diorites, granodiorites, and the Omineca alkali-feldspar syenites have the largest negative $\mathrm{Eu}$ anomalies $\left(\mathrm{Eu} / \mathrm{Eu}^{* *}=\right.$ $0.08-0.42$ ). Apatites from the alkalic porphyry $\mathrm{Cu}-\mathrm{Au}, \mathrm{Au}-\mathrm{Co}$ skarn, Wernecke IOCG breccia, and orogenic Au deposits each span almost the entire range of the $\mathrm{Eu} / \mathrm{Eu}^{*}$ values in this study, with some of the within-group variations being due to the difference between the individual deposits (Figs. 5, 6). Other apatite groups have more restricted ranges of $\mathrm{Eu} / \mathrm{Eu}^{*}$ (e.g., porphyry $\mathrm{Cu} \pm \mathrm{Mo} \pm \mathrm{Au}$, porphyry $\mathrm{Mo}$, and orogenic $\mathrm{Ni}-\mathrm{Cu}$ ), which are quite distinct from each other and from the $\mathrm{Eu} / \mathrm{Eu}^{*}$ ranges of apatites from carbonatites and unmineralized rocks (Fig. 6). It would appear that the Eu anomalies 


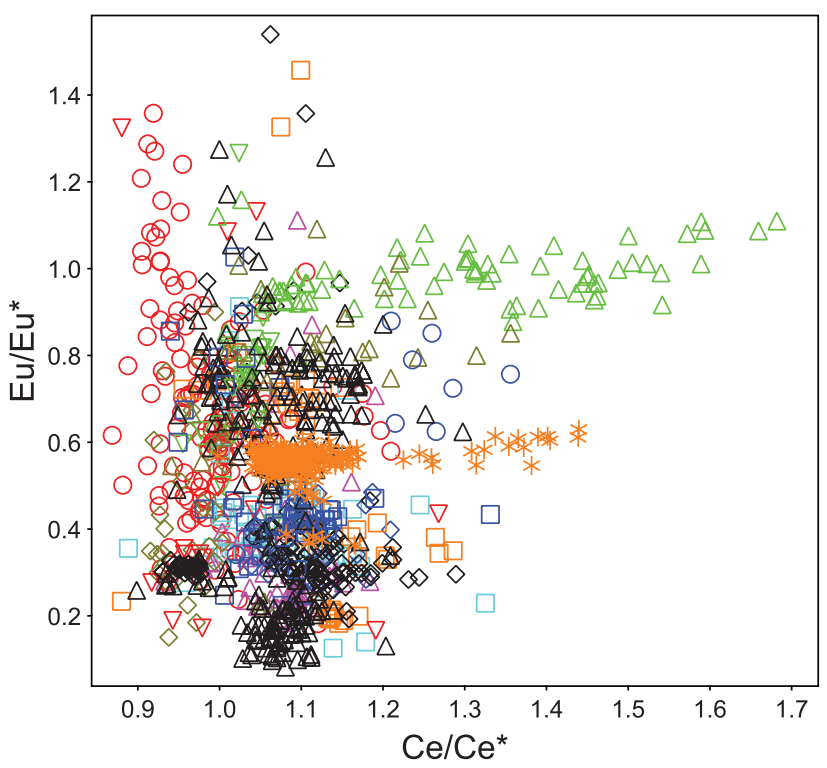

\begin{tabular}{|c|c|c|c|}
\hline & Carbonatites, phoscorites, & O & Alkalic porphyry Cu-Aı \\
\hline$\square$ & MOR & $\diamond$ & Porphyry Cu-Au \\
\hline & IOCG and Kiruna-type & $\triangle$ & Porphyry Cu-Mo \\
\hline & Orogenic Au & $\square$ & Porphyry Mo \\
\hline & Orogenic $\mathrm{Ni}-\mathrm{Cu}$ & $\diamond$ & $\begin{array}{l}\text { Porphyry-related } \\
\text { Cu-Au breccia }\end{array}$ \\
\hline 0 & Epithermal Au-Ag & $\Delta$ & Unmineralized rocks \\
\hline$\nabla$ & $\begin{array}{l}\mathrm{Au}-\mathrm{Co}, \mathrm{Cu}, \text { and } \\
\mathrm{Pb}-\mathrm{Zn} \text { skarns }\end{array}$ & * & $\begin{array}{l}\text { Madagascar apatite } \\
\text { standard }\end{array}$ \\
\hline & W skarn & & \\
\hline
\end{tabular}

Fig. 6. $\mathrm{Ce} / \mathrm{Ce}^{*}$ vs. $\mathrm{Eu} / \mathrm{Eu}^{*}$ plot for apatites; $\mathrm{Ce} / \mathrm{Ce}{ }^{*}=\mathrm{Ce}_{\mathrm{CN}} \cdot\left(\mathrm{LaCN}_{\mathrm{CN}} \cdot \mathrm{Pr}_{\mathrm{CN}}\right)^{-0.5}$; $\mathrm{Eu} / \mathrm{Eu}^{*}=\mathrm{Eu}_{\mathrm{CN}} \cdot\left(\mathrm{Sm}_{\mathrm{CN}} \cdot \mathrm{Gd}_{\mathrm{CN}}\right)^{-0.5}$. Normalization values are from Lodders (2010).

in apatites will be effective in discriminating the different deposit types.

\section{Vanadium and arsenic}

Vanadium concentrations in most apatite grains are $<100 \mathrm{ppm}$, with most sample suites possessing apatite grains with detectable $\mathrm{V}$ (usually $>10 \mathrm{ppm}$ ). The lowest $\mathrm{V}$ contents $(<12 \mathrm{ppm})$ distinguish apatites from the Au-Co skarn, W skarn, orogenic $\mathrm{Ni}-\mathrm{Cu}$, and orogenic $\mathrm{Au}$ groups. The highest $\mathrm{V}$ concentrations, ranging from $<2.5$ to $337 \mathrm{ppm}$, generally characterize apatites from alkalic porphyry $\mathrm{Cu}$-Au deposits. Apatites from carbonatites are an exception to this finding where $~ 14 \%$ of apatite analyses have $\mathrm{V}$ contents $>100 \mathrm{ppm}$, with apatites from Magnet Cove and Oka containing up to 1,466 and $500 \mathrm{ppm}$, respectively (Table 4; Fig. 4). Most of the apatite analyses from the Kiruna-type and unmineralized quartz monzonite and syenitic rocks also contain relatively high $\mathrm{V}$ contents (9-151 ppm). High V contents in apatite suggest not only high $\mathrm{V}$ content in host rocks (Cao et al., 2012), but also a high oxygen fugacity during apatite crystallization owing to substitution mechanism that preferentially incorporates $\mathrm{V}^{5+}$ in apatite (Kutoglu, 1974; Sha and Chappell, 1999).

Arsenic concentrations are $<100 \mathrm{ppm}$ in most apatites, but are much higher (176-2,251 ppm) in apatites from two
Kiruna-type samples (Durango and Great Bear) and one orogenic Au vein sample (Seabee). Apatites from IOCG, Kirunatype, and porphyry-related $\mathrm{Cu}-\mathrm{Au}$ breccia deposits contain As concentrations above the detection limit (2.3-11 ppm). Apatites from both the Wernecke IOCG and porphyryrelated $\mathrm{Cu}-\mathrm{Au}$ breccias also have relatively high As contents (9-506 ppm). For Au-Co skarn, orogenic Au, alkalic porphyry $\mathrm{Cu}-\mathrm{Au}$, porphyry $\mathrm{Cu}-\mathrm{Mo}$, porphyry $\mathrm{Mo}$, and unmineralized rock groups, more than half of the analyzed apatites from each group contain As higher than the detection limit, and As is only rarely present in apatites from the other sample suites. Incorporation of As in apatite is redox sensitive, and $\mathrm{AsO}_{4}^{3-}$ readily substitutes for $\mathrm{PO}_{4}^{3-}$ in apatite as opposed to $\mathrm{As}^{3+}$, which is accommodated in (arseno)sulfides (Sha and Chappell, 1999). Therefore, low As concentrations in apatite may indicate low $\mathrm{As}^{5+} / \mathrm{As}^{3+}$ in the reducing environment, or early crystallization of As-bearing phases. Because As is usually enriched in sedimentary rocks, low As contents in apatite may be also useful in ruling out a sedimentary source.

\section{Zirconium, thorium, and uranium}

Zirconium concentrations in apatites are usually $<1 \mathrm{ppm}$, except from MORs, carbonatites, unmineralized rocks, and alkalic porphyry $\mathrm{Cu}-\mathrm{Au}$ and epithermal $\mathrm{Au}-\mathrm{Ag}$ deposits. The apatites from MORs, carbonatites, and epithermal $\mathrm{Au}-\mathrm{Ag}$ deposits have the highest $\mathrm{Zr}$ contents in this study, ranging from less than the detection limit $(0.2-1.0 \mathrm{ppm})$ to $153 \mathrm{ppm}$ in apatite from one carbonatite sample (Oka). Eighty-eight percent of analyzed apatite grains from the alkalic porphyry $\mathrm{Cu}-\mathrm{Au}$ deposits contain between 1 and $15 \mathrm{ppm} \mathrm{Zr}$.

Thorium contents in most of the apatites are between 0.4 and $661 \mathrm{ppm}$. Only the Madagascar apatite has higher Th contents of up to $910 \mathrm{ppm}$. Thorium concentrations in apatites from the porphyry $\mathrm{Cu}-\mathrm{Mo}$, porphyry-related $\mathrm{Cu}-\mathrm{Au}$ breccia, Wernecke IOCG breccia, orogenic Au, and MOR groups are typically $<8 \mathrm{ppm}$, whereas most of the Kiruna-type apatites contain from 102 to $262 \mathrm{ppm}$ Th. Due to the large variations between the apatite groups, Th contents are expected to help discriminate between the different deposit types.

Uranium concentrations range from $<0.02$ to $119 \mathrm{ppm}$ in all studied apatites, except for the single apatite from the Omineca alkali-feldspar syenite (681 ppm). The apatites from carbonatites show the widest range of $\mathrm{U}$ contents for a single group in this study (0.01-115 ppm), whereas most of the apatites from the epithermal $\mathrm{Au}-\mathrm{Ag}$ deposits contain between 11 and $119 \mathrm{ppm}$ U. Uranium contents in apatites from other groups are generally $<30$ ppm (Table 4; Fig. 4).

\section{Copper, zinc, rubidium, niobium, molybdenum, and tungsten}

Although these elements are rarely present at concentrations above the detection limits (App. Table 4; Table 3) in the analyzed apatites, detectable levels of some of these elements may be diagnostic for specific deposit groups (Table 4; Fig. 4). Unfortunately, we are unable to fully investigate the significance of these trace elements in apatites due to the variable detection limits from less than $1 \mathrm{ppm}$ to tens of $\mathrm{ppm}$, for individual LA-ICPMS sessions (App. Table 4).

Rubidium concentrations are low (1-4 ppm) in Madagascar apatite and in apatites from the alkalic porphyry $\mathrm{Cu}-\mathrm{Au}$, porphyry Mo, carbonatite, and unmineralized diorite-granodiorite 
groups. Rubidium is below the detection limit in apatites from the other groups. Molybdenum was detected in a single apatite grain from both the Boss Mountain and Cassiar Moly porphyry Mo deposits (15 and 40 ppm, respectively), and in two analyses from a sample of unmineralized alkali-feldspar syenite from the Abitibi belt (1.0 and $1.3 \mathrm{ppm}$ ).

Zinc is detectable (12-46 ppm) in 50\% of the apatites from the porphyry $\mathrm{Cu}-\mathrm{Au}$ subclass (Kemess South) but not in other porphyry deposits, excluding a single apatite grain from the alkalic porphyry $\mathrm{Cu}-\mathrm{Au}$ subclass (Dobbin). Similarly, Zn was detected (3-4 ppm) in 30\% of the apatites from a single orogenic $\mathrm{Au}$ deposit (Congress). Zinc is present (2-17 ppm) in some apatite grains from carbonatites (Alnö and Manitou Islands), MOR (Hess Deep), diorite (Thiemer Creek), and the epithermal $\mathrm{Au}-\mathrm{Ag}$ (Cripple Creek) groups.

The highest $\mathrm{Cu}$ contents $(<5-736 \mathrm{ppm})$ occur in apatites from alkalic porphyry $\mathrm{Cu}-\mathrm{Au}$ deposits, with most apatites (20\%) from Dobbin. Copper is detected in $10 \%$ of the analyzed apatites from the Willa porphyry-related $\mathrm{Cu}-\mathrm{Au}$ breccia deposit (0.5-39 ppm). Noteworthy for other groups are a few apatites (4-11\% analyses per group) with appreciable $\mathrm{Cu}$ from the Vancouver Island diorites and granodiorites (12407 ppm), the Abitibi alkali-feldspar syenites (5-9 ppm), and the Wernecke IOCG breccia (6-33 ppm). Detectable Cu contents are rarely present in other apatite groups (5-64 ppm).

Elevated $\mathrm{Nb}$ contents (up to $19 \mathrm{ppm}$ ) are diagnostic of apatites from carbonatites, which show detectable $\mathrm{Nb}(>0.4 \mathrm{ppm})$ in $40 \%$ of the samples. For other samples, only one grain from the Cripple Creek epithermal Au-Ag deposit and three Madagascar apatite analyses have measurable Nb (3 and 0.11.4 ppm, respectively).

Tungsten was detected in $20 \%$ of the analyzed apatite grains (>0.01 ppm), although $80 \%$ of all analyses had much higher detection limits (up to $3.5 \mathrm{ppm}$ ), exceeding the $75^{\text {th }}$ percentile of all quantitative results and, therefore, were discarded (App. Table 4). Most of the analyzed apatites from the Au-Co skarn (90\%) and porphyry-related Cu-Au breccia (80\%) deposits contain detectable $\mathrm{W}$ at similar concentrations (1-10 ppm). Most of other groups include $7-40 \%$ apatites with detectable $\mathrm{W}$ levels, except the porphyry $\mathrm{Cu}-\mathrm{Au}$ group (single analysis). Notably, the apatites from MORs have the highest $W$ contents $(<0.2-17 \mathrm{ppm})$, whereas those from carbonatites have the lowest contents $(<0.05-0.6 \mathrm{ppm})$ in this study. The W content of apatites, therefore, may be diagnostic for these rock types, although $\mathrm{W}$ contents in apatites from the Kiruna-type deposits span almost the entire range of values reported in this study $(<0.02-16 \mathrm{ppm})$. Most of the results from other apatite groups range between $<0.02$ and 6 ppm $\mathrm{W}$, excluding Madagascar apatite, which generally has a lower $\mathrm{W}$ content $(<0.05-3.3 \mathrm{ppm})$.

\section{Discussion}

Trace elements data for apatites from the different types of deposits reveal that the abundances of some trace elements vary depending upon the deposit type. Consequently, trace elements have the potential for discriminating between the various deposit types. For example, the apatites from carbonatites contain the highest $\mathrm{Nb}$ and lowest $\mathrm{W}$ contents in this study. Also, apatites from porphyry $\mathrm{Cu}-\mathrm{Au}$ deposits have the highest $\mathrm{Y}$ and $\mathrm{Yb}$, and the apatites from alkalic porphyry
$\mathrm{Cu}-\mathrm{Au}$ deposits have the highest $\mathrm{V}$ contents (Fig. 4). For most types of deposits, however, it is impossible to use one or two elements to differentiate one group from all others. Therefore, multi-element discrimination diagrams have been developed to allow the parental lithology or deposit type to be determined from apatite compositions.

\section{Discriminant analysis}

In order to determine the optimum criteria for discriminating between barren rocks and various deposits using apatite trace element compositions, we have undertaken a Discriminant Projection Analysis (DPA) in ioGAS ${ }^{\circledR}$ software. DPA is a multivariate statistical technique that determines an optimum projection of multivariate data into a lower dimensional space to achieve the best separation between user-defined groups (Flury, 1997). The DPA uses an a priori knowledge of the group memberships to define these projection "rules" or functions. Specifically, the DPA calculates a set of linear discriminant functions that maximize the ratio of the within-groups $(\mathrm{W})$ to between-groups (B) sum of squares matrices (W/B). The between-groups matrix is effectively the covariance of the group means and the within-groups matrix is the weighted covariance matrix for all the groups. These discriminant functions or projections (DP1, DP2, etc.) are linear combinations of the original variables (i.e., element concentrations) that maximize the differences between the predefined groups, which allow the samples to be plotted in the discriminant space so that group separation can be visualized and investigated. The DPA also indicates which of the selected variables are most important for determining maximum group separation based on the size of the structure coefficient.

\section{Methodology}

The DPA on apatite data involved three steps to discriminate apatites associated with mineralization versus unmineralized samples and different deposit types (Table 5). The number of samples for each group varies depending on selected elements (App. Table 5). Because all variables of the multivariate discriminant functions must be not nulls, we used only elements that were analyzed in all apatite grains $(\mathrm{Mg}, \mathrm{V}, \mathrm{Mn}, \mathrm{Sr}$, Y, La, Ce, Eu, Dy, Yb, Pb, Th, and U). Most of these elements have concentrations above the minimum detection limits (DL) in all studied apatites; the percentage of analyses $<\mathrm{DL}$ does not exceed $14 \%$ for $\mathrm{Pb}, 11 \%$ for $\mathrm{V}, 7 \%$ for $\mathrm{Mg}, 2 \%$ for $\mathrm{Th}$, and $0.4 \%$ for $\mathrm{U}$ (App. Table 4). To maximize the number of multivariate samples, DPA calculations used combinations of up to 11 elements.

The DPA structure coefficients of the discriminant functions highlight critical variables that distinguish the groups (App. Table 5A). In addition to the calculated discriminant functions, the key elements determined by the DPA can be used to construct simplified discrimination diagrams for some of the apatite groups.

To statistically outline samples within each group on the discrimination diagrams, we used contours of constant Mahalanobis distance (MD) calculated in ioGAS ${ }^{\circledR}$ software. The MD is a measure of central tendency of the multivariate data that takes into account the shape of the data (Mahalanobis, 1936; De Maesschalck et al., 2000). The MD is conceptually similar to univariate Z-score as a measure of distance of 


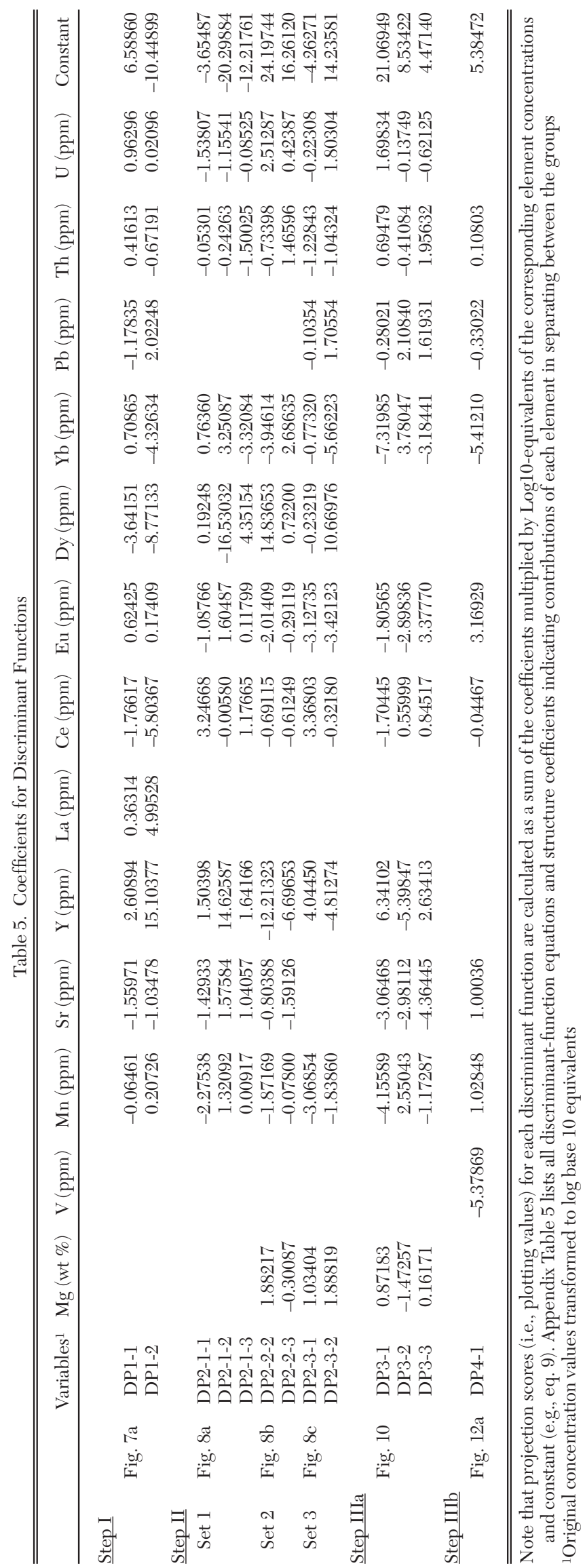

a sample point from center in terms of the number of standard deviations from mean. Mahalanobis distance is based on the means and variances for the variables, and on the covariances between each pair of variables. The contour of constant MD is always an ellipse for two variables and an ellipsoid in a higher dimensional space.

To minimize the impact of atypical values or outliers, we used a robust algorithm for the MD calculation that downweighs "extreme" sample values (Campbell, 1980). The MD contours on all of the discrimination diagrams are shown for an outlier cutoff of 0.95 percentile of the chi-squared distribution. The calculated robust MD contours provide the basis for linear boundaries between the groups of apatite data on the final discrimination diagrams (App. Figs. 1-4). Appendix Table 6 provides worked examples of apatite data, with input and output (calculated DP scores) tables, and live discrimination diagrams for each step. Below we discuss the three-step DPA results based on the apatite data from known deposits comprising our training dataset. The DPA and statistically defined linear boundaries between the training apatite groups constitute the basis of the proposed discrimination diagrams, which we further test using available apatite analyses from literature.

\section{Discrimination of apatites from different deposits and unmineralized rocks (step $I, D P 1$ )}

The purpose of the first discrimination step is to separate apatites from various mineralized systems, carbonatites, and related rocks, and rocks not associated with known mineralization. By using 11 elements (Mn, Sr, Y, La, Ce, Eu, Dy, $\mathrm{Yb}, \mathrm{Pb}$, Th, and $\mathrm{U})$, the discriminant-function scores for each sample are obtained as follows:

$$
\begin{gathered}
\mathrm{DP} 1-1=-0.06461 \cdot \log (\mathrm{Mn})-1.56 \cdot \log (\mathrm{Sr})+2.609 \cdot \log (\mathrm{Y}) \\
+0.3631 \cdot \log (\mathrm{La})-1.766 \cdot \log (\mathrm{Ce})+0.6243 \cdot \log (\mathrm{Eu}) \\
-3.642 \cdot \log (\mathrm{Dy})+0.7086 \cdot \log (\mathrm{Yb})-1.178 \cdot \log (\mathrm{Pb}) \\
+0.4161 \cdot \log (\mathrm{Th})+0.963 \cdot \log (\mathrm{U})+6.589
\end{gathered}
$$

Table 5 provides the projection coefficients and constants for all of the discriminant functions. The numbering of functions reflects the discrimination step, DPA set (if more than one DPA were performed for a given step), and discrimination function number (e.g., DP2-1-1 represents the discrimination step II, the first set of functions, and the first discriminant function). These coefficients are applied to logarithms of the concentration values, and all the DPA functions are calculated similarly to the equation (9) (App. Table 5B).

Discriminant functions DP1-1 vs. DP1-2 (Fig. 7a) separate most of the apatite data from carbonatites, various mineralized systems, and the unmineralized rocks. Some data from the Abitibi syenites partly overlap with carbonatites, reflecting a close temporal and spatial association of some of these plutons with carbonatites. A few data points from the mineralized groups that also fall within the carbonatite field are for one sample from Cripple Creek epithermal Au-Ag and for Dentonia orogenic Au deposits. However, most of the apatite data from MORs and the unmineralized diorites and granodiorites fall within the field of various ore deposits in the DP diagram (Fig. 7a). The apatites from MORs can be further discriminated by their relatively high $\mathrm{Zr}$ and low Sr contents (Fig. 7b), coupled with their relatively high $\mathrm{Mg}$ and $\mathrm{W}$ contents (Fig. 4a; 
(a)
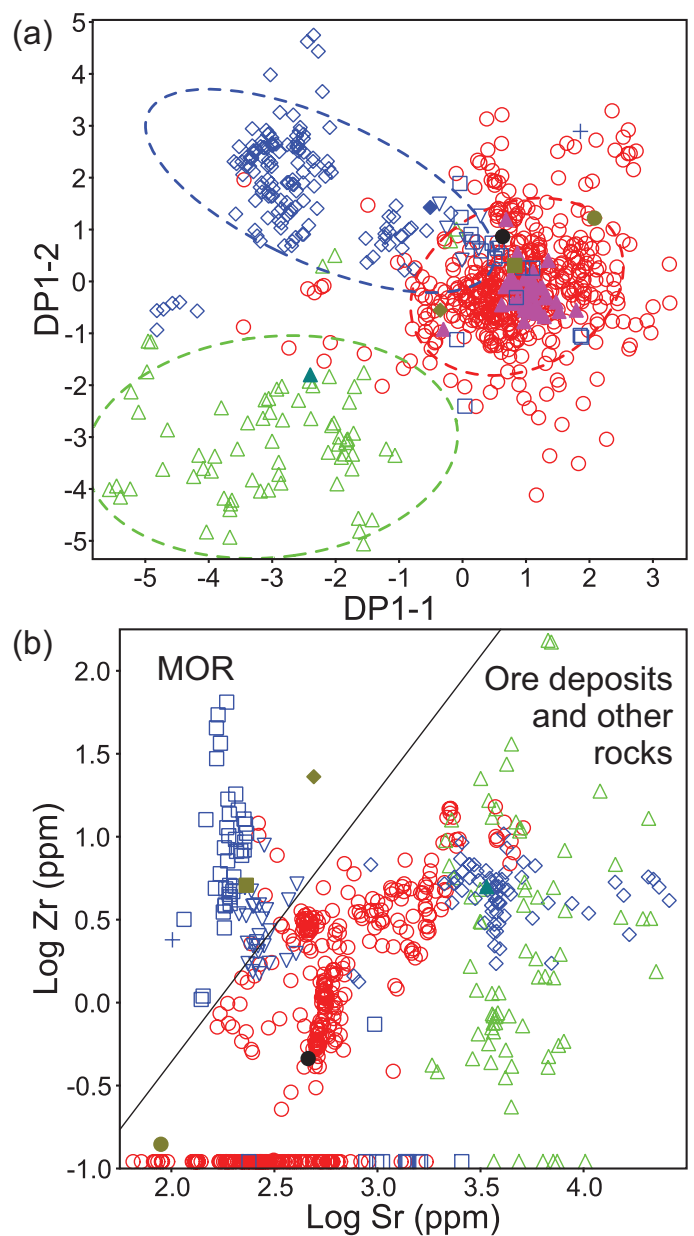

(c)

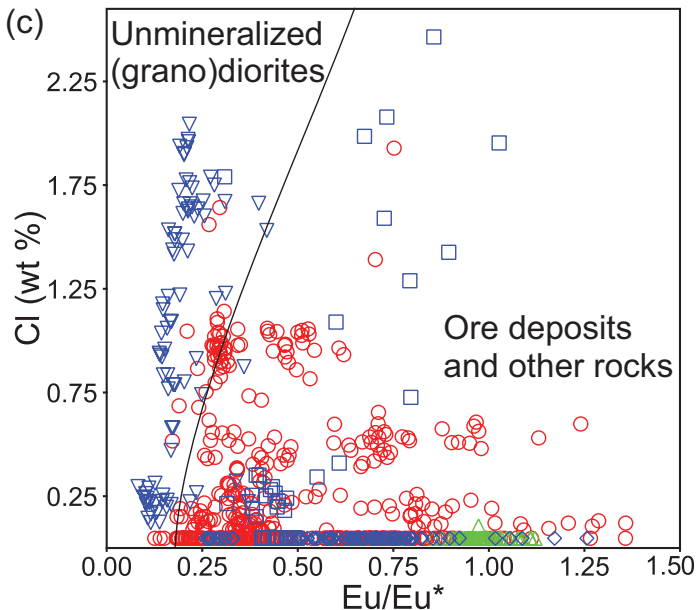

$\triangle$ Carbonatites, phoscorites, and associated ijolites

Ore deposits

Unmineralized rocks:

$\square$ Mid-ocean ridge gabbros

$\diamond$ Abitibi clinopyroxenite, syenites, and quartz monzonite

$\nabla$ Vancouver Island diorites and granodiorites

+ Omineca metasyenite

\section{Literature data:}

- Unmineralized batholith

- Porphyry Cu-Mo

- Kiruna-type

- Carbonatite

- Dolerite

- Syenite

- Granite pegmatite

Fig. 7. Discrimination diagrams for apatites from carbonatites, various ore deposits, and rocks that are not associated with mineralization. Also shown are literature data (Belousova et al., 2002; Cao et al., 2012) that were not used in DPA for construction of the discrimination diagrams. a) The first discriminant function (DP1-1) vs. the second discriminant function (DP1-2), showing contours of constant Mahalanobis distance outlining bulk of the data in each group (step I; Table 5; App. Table 5); DP1-1 $=-0.06461 \cdot \log \mathrm{Mn}-1.56 \cdot \operatorname{logSr}+2.609 \cdot \log \mathrm{Y}+0.3631 \cdot \log \mathrm{La}-1.766 \cdot \log \mathrm{Ce}+0.6243 \cdot \log \mathrm{Eu}-3.642 \cdot \log \mathrm{Dy}$ $+0.7086 \cdot \log \mathrm{Yb}-1.178 \cdot \log \mathrm{Pb}+0.4161 \cdot \log \mathrm{Th}+0.963 \cdot \log \mathrm{U}+6.589 ; \mathrm{DP} 1-2=0.2073 \cdot \log \mathrm{Mn}-1.035 \cdot \operatorname{logSr}+15.1 \cdot \log \mathrm{Y}+$ $4.995 \cdot \log \mathrm{La}-5.804 \cdot \log \mathrm{Ce}+0.1741 \cdot \log \mathrm{Eu}-8.771 \cdot \log \mathrm{Dy}-4.326 \cdot \log \mathrm{Yb}+2.022 \cdot \log \mathrm{Pb}-0.6719 \cdot \log \mathrm{Th}+0.02096 \cdot \log \mathrm{U}-$ 10.45; variables are $\log 10$-equivalents of element concentrations in ppm. b) $\log \mathrm{Sr}$ (ppm) vs. log $\mathrm{Zr}$ (ppm) with boundary separating bulk of the data for mid-ocean ridge (MOR) from ore deposits and other rocks based on the lowest Mahalanobis distance. c) $\mathrm{Eu} / \mathrm{Eu}^{*} \mathrm{vs}$. $\mathrm{Cl}$ (wt \%) with boundary separating bulk of the data for unmineralized diorites and granodiorites from ore deposits and other rocks based on the lowest Mahalanobis distance; $\mathrm{Eu} / \mathrm{Eu}^{*}=\mathrm{Eu}_{\mathrm{CN}} \cdot\left(\mathrm{Sm}_{\mathrm{CN}} \cdot \mathrm{Gd}_{\mathrm{CN}}\right)^{-0.5}$.

Table 4) and relatively low LREE/HREE (Fig. 5a). An exception is the apatite from highly altered MORs from the MidAtlantic Ridge, which have much lower Zr contents (mostly below the detection limit) and elevated Sr contents. It is noteworthy that the apatites from diorites and granodiorites have consistent negative $\mathrm{Eu}$ anomalies $\left(\mathrm{Eu} / \mathrm{Eu}^{*}=0.08-0.42-\right.$ among the largest negative Eu anomalies observed in this study), and many of these apatites contain elevated $\mathrm{Cl}$ contents compared with other apatite groups (Table 4). Therefore, apatites from unmineralized diorites and granodiorites can be further discriminated from other apatites in terms of their Eu/Eu* vs. Cl content (Fig. 7c).

In general, apatites from the mineralized groups have higher $\mathrm{Ca}$ and lower total contents of trace elements that partition onto the Ca sites (REE, Y, Mn, Sr, Pb, Th, U) than apatites from unmineralized rocks and carbonatites (Fig. 3a). A similar observation was reported by Bouzari et al. (2011), who investigated apatites from altered and fresh zones from three porphyry deposits. They attributed the slightly higher Ca contents of apatites from altered zones to loss of trace elements during hydrothermal alteration and constraints of closure on analytical data totals to $100 \mathrm{wt} \%$. An alternative hypothesis is that the apatites in mineralized rocks crystallized from hydrothermal fluids that contained relatively low concentrations of the elements that partition onto the Ca sites. This is due to the relatively lower temperatures and pressures of crystallization, resulting in lower solubilities of many trace elements in most aqueous fluids compared to silicate melts.

Unlike the apatites from other unmineralized groups, the apatites from MOR (the unmineralized group) have $\mathrm{Ca}$ and trace element content levels similar to the apatites from mineralized groups, most likely because the parental MOR melts are depleted in trace elements. Interestingly, apatites from one completely altered MOR sample (209 1270D 4R2 pc5: 
App. Table 4; Grimes et al., 2011) contain higher Na, Cl, La, $\mathrm{Mn}, \mathrm{Sr}$, and Ce and lower HREE, Y, and Zr than apatites from other MORs. This difference probably reflects apatite crystallization during greenschist facies fluid-rock reactions.

Apatites from carbonatites are characterized by high $\mathrm{Si}$ (<0.05-1.3 wt \%), V (<2-1,466 ppm), Sr (1,840-22,498 ppm), $\mathrm{Nb}(<0.4-19 \mathrm{ppm}), \mathrm{Ba}(1.8-275 \mathrm{ppm})$, and Th (1.6-661 ppm) contents, the lowest W $(<0.05-0.55 \mathrm{ppm})$ contents, strongly LREE enriched REE distribution, positive Ce anomalies (Ce/ $\left.\mathrm{Ce}^{*}=1.0-1.7\right)$, and by the lack of Eu anomalies $\left(\mathrm{Eu} / \mathrm{Eu}^{*}=\right.$ 0.9-1.2; Figs. 4a, 5a). Carbonate melts are characterized by very high $\mathrm{Sr}, \mathrm{Ba}, \mathrm{P}, \mathrm{V}$, and REE (LREE-enriched) abundances (Nelson et al., 1988; Bell, 1989, 2005; Hammouda et al., 2010; Jones et al., 2013), explaining the consistently high Sr, Ba, and LREE in apatites from carbonatites. Similar to Eu in wholerock carbonatite data, apatites from carbonatites also show no $\mathrm{Eu}$ anomalies, consistent with little or no fractionation of feldspar from these magmas (Cullers and Medaris, 1977; Bell, 1989; Belousova et al., 2002; Ani and Sarapää, 2009). The moderate positive Ce anomalies in apatites from carbonatites also imitate positive whole-rock Ce anomalies (Ani and Sarapää, 2009). Niobium, a very incompatible element in apatites (Klemme and Dalpé, 2003), is detectable (up to 19 ppm) in apatites almost exclusively from carbonatites (Table 4), likely reflecting the very high $\mathrm{Nb}$ content of the carbonatite melt (Scales, 1989; Jones et al., 2013).

\section{Discrimination of general deposit types (step II, DP2)}

The objective of the second step is to differentiate the mineralized apatites into the main deposit types: porphyry $\mathrm{Cu}$ Au-Mo, epithermal Au-Ag, IOCG, skarn, orogenic Au, and orogenic $\mathrm{Ni}-\mathrm{Cu}$ ore systems. Due to limited numbers of apatites from epithermal Au-Ag deposits (9 grains from 3 samples), this group is combined with porphyry deposits and will not be discriminated in the following steps. This step discriminates apatites from orogenic $\mathrm{Ni}-\mathrm{Cu}$, orogenic $\mathrm{Au}$, and undivided IOCG and Kiruna-type deposits. Various types of porphyries, skarn, IOCG, and Kiruna-type deposits are subdivided in subsequent steps.

Six discriminant functions from three different sets of DPA using Mn, Y, Ce, Eu, Dy, Yb, Th, and U $( \pm \mathrm{Mg} \pm \mathrm{Sr} \pm \mathrm{Pb})$ were found to effectively discriminate these groups (Fig. 8; Table 5 ). The first two axes (DP2-1-1 vs. DP2-1-2 and DP2-3-1 vs. DP2-3-2) from the DP2 sets 1 and 3 discriminate $>90 \%$ of apatites from iron oxide-associated deposits (IOCG breccia and Kiruna-type) from the other groups (Fig. 8a, c). Likewise, the second and third axes from the DP2 set 2 discriminate W skarn (together with orogenic Ni-Cu) from orogenic $\mathrm{Au}$ and Au-Co skarn deposits (Fig. 8b). The first and the second discriminant functions from the DP2 set 3 also best separate the orogenic Au from porphyry and from Au-Co skarn (Fig. 8c). Most of the apatites from the orogenic $\mathrm{Au}$ and orogenic $\mathrm{Ni}-\mathrm{Cu}$ deposits can be separated from other deposit types (Fig. 8). However, apatites from porphyry, W skarn, and Au-Co skarn are not separated from one another in the DP2 discrimination diagrams. A 3-D projection of the DP2 set 1 axes DP2-1-1, DP2-1-2, and DP2-1-3 (App. Movie 1) illustrates the power of the DPA functions in discriminating between the different groups of apatite data, some of which appear to overlap in the 2-D diagrams.
The apatites from iron oxide-associated deposits are from three Kiruna-type deposits (Aoshan, Great Bear, and Cerro de Mercado) and one postorogenic IOCG breccia deposit (Wernecke). Most of these apatites have consistently negative $\mathrm{Eu}$ anomaly values, typically from 0.2 to 0.5 , and low Mn contents (<300 ppm; Fig. 9a). However, 11 grains from the Wernecke IOCG breccia show much higher $\mathrm{Eu} / \mathrm{Eu}^{*}$, from 0.7 to 1.5 , and some of these grains and a few others from this deposit have high $\mathrm{Mn}$ contents (up to 5,753 ppm). A recent model (Hunt et al., 2011) suggests that the Wernecke ore fluids were derived from formational waters via dewatering of the host sedimentary basin. No temporally associated igneous rocks are recognized. Elevated As abundances in the Wernecke apatites (mostly 42-358 ppm As) are consistent with a sedimentary source. The unusual geochemistry of some apatites from the Wernecke breccia compared with that of Kirunatype deposits in our study may reflect a different origin for this deposit, as proposed by Hunt et al. (2011).

The low Mn concentration in most of the apatites from Kiruna-type deposits may be due to the associated mineral assemblage. Apatites from the three Kiruna-type deposits are intergrown with abundant magnetite and commonly actinolite (Lyons, 1988; Dong, 2005; Acosta-Góngora et al., 2014), both of which incorporate Mn (Paster et al., 1974; Ewart and Griffin, 1994). Likewise, apatites from the Wernecke IOCG breccias are part of a hydrothermal alteration assemblage that includes albite, K-feldspar, and magnetite (Brookes et al., 2001; Hunt et al., 2011). The magnetite may have sequestered large amounts of $\mathrm{Mn}$ and the prominent negative Eu anomalies in the apatites may be caused by the presence of albite and $\mathrm{K}$-feldspar, which incorporate Eu more readily than other REEs, leading to negative Eu anomalies in the coexisting phases (Leeman and Phelps, 1981; Bea et al., 1994). Consistent with the findings of Barton and Johnson (1996) and Oliver et al. (2004), who proposed that brine is involved during the $\mathrm{K} / \mathrm{Na}$ alteration stage of Kiruna-type deposits, our results show that apatites from the Aoshan Kiruna-type deposit contain between $<0.07$ and 1.14 wt \% Cl. Most of the other Kiruna-type apatites contain detectable Cl (up to 0.7 wt \%; Table 4), which supports the involvement of a Cl-rich fluid in the formation of these deposits.

All apatites from the orogenic $\mathrm{Ni}-\mathrm{Cu}$ group are from the Jason mine in British Columbia. These apatites are characterized by very low concentrations of impurity cations, especially the HREEs (Figs. 3a, 5b), Yb (2-9 ppm) and Eu (5-10 ppm) (Fig. 9c). These findings are considered preliminary, however, because apatite data are restricted to one deposit. Additional apatites from different orogenic $\mathrm{Ni}-\mathrm{Cu}$ deposits are required to confirm these trace element characteristics.

Although the apatites from different orogenic Au deposits display variable trace element behavior (Fig. 9), they are effectively discriminated by the DPA functions (Fig. 8c). The apatites from the Seabee and Dentonia mines have the lowest $(\mathrm{La} / \mathrm{Sm})_{\mathrm{CN}}$ values $(<0.4$; Fig. 9d), possibly due to the presence of monazite and allanite, which incorporate the LREE over the MREE (Mahood and Hildreth, 1983; Michael, 1988). Both of these minerals were recognized in thin sections from Seabee and Dentonia (App. Table 1). The Dentonia samples also show a large positive Eu anomaly $\left(\mathrm{Eu} / \mathrm{Eu}^{*}=\right.$ 1.3-1.5), which is atypical of apatites analyzed in this study. 
(a)

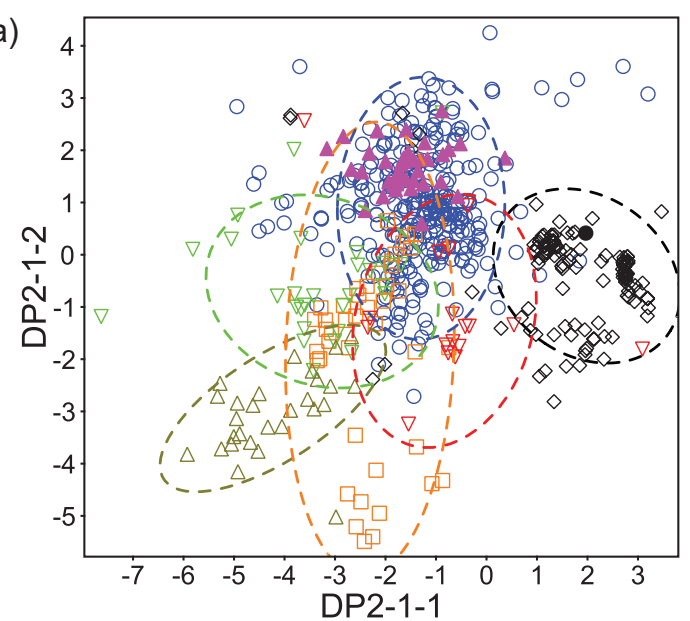

(b)

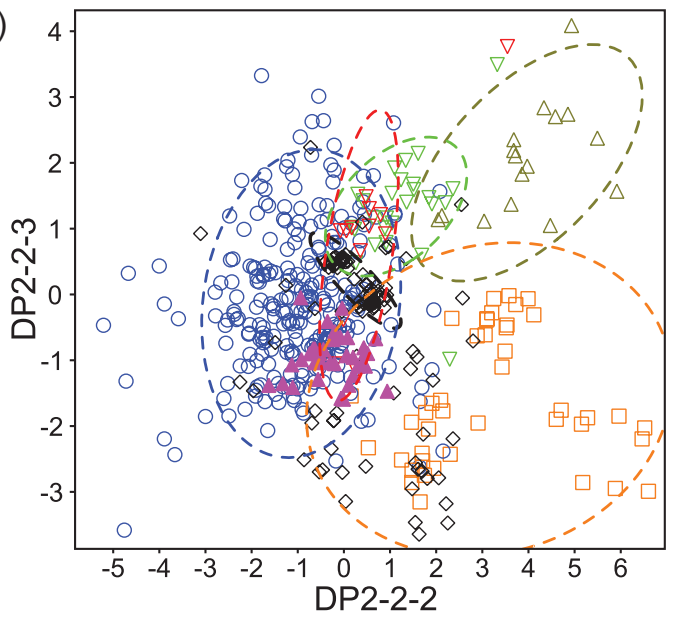

(c)

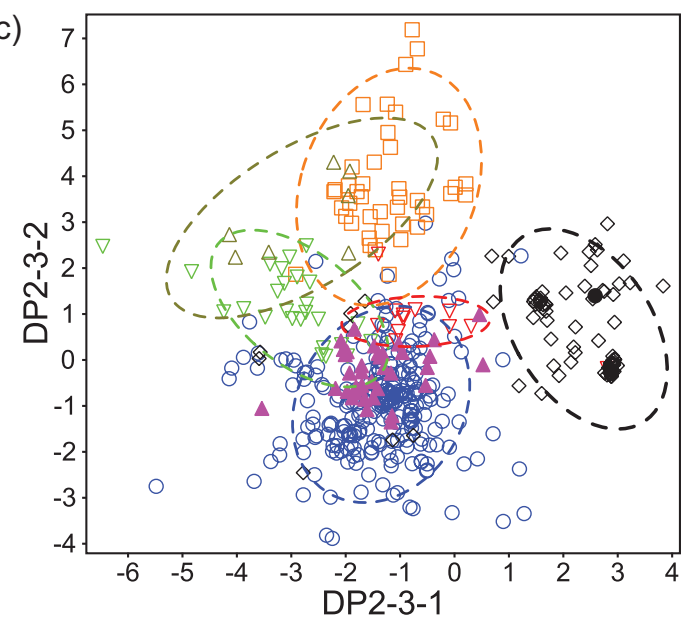

$\diamond$ IOCG and Kiruna-type

$\triangle$ Orogenic $\mathrm{Ni}-\mathrm{Cu}$

Orogenic Au

O Porphyry Cu-Mo-Au and epithermal Au-Ag

$\nabla$ W skarn

$\nabla$ Au-Co, $\mathrm{Cu}$, and $\mathrm{Pb}-\mathrm{Zn}$ skarns

Literature data:

A Porphyry Cu-Mo

- Kiruna-type

Fig. 8. Discrimination diagrams for apatites from different ore deposits, showing contours of constant Mahalanobis distance outlining bulk of the data in each group (step II; Table 5; App. Table 5). Also shown are literature data (Belousova et al., 2002; Cao et al., 2012) that were not used in DPA for construction of the discrimination diagrams. a) The first discriminant function (DP2-1-1) vs. the second discriminant function (DP2-1-2); DP2-1-1 $=-2.275 \cdot \log \mathrm{Mn}-1.429 \cdot \log \mathrm{Sr}+1.504 \cdot \log \mathrm{Y}+$ $3.247 \cdot \log \mathrm{Ce}-1.088 \cdot \log \mathrm{Eu}+0.1925 \cdot \log \mathrm{Dy}+0.7636 \cdot \log \mathrm{Yb}-0.05301 \cdot \log \mathrm{Th}-1.538 \cdot \log \mathrm{U}-3.655 ; \mathrm{DP} 2-1-2=1.321 \cdot \operatorname{logMn}$ $+1.576 \cdot \log \mathrm{Sr}+14.63 \cdot \log \mathrm{Y}-0.005804 \cdot \log \mathrm{Ce}+1.605 \cdot \log \mathrm{Eu}-16.53 \cdot \log \mathrm{Dy}+3.251 \cdot \log \mathrm{Yb}-0.2426 \cdot \log \mathrm{Th}-1.155 \cdot \log \mathrm{U}-$ 20.30 . b) The second discriminant function (DP2-2-2) vs. the third discriminant function (DP2-2-3); DP2-2-2 $=1.882 \cdot \log \mathrm{Mg}$ $-1.872 \cdot \log \mathrm{Mn}-0.8039 \cdot \operatorname{logSr}-12.21 \cdot \log \mathrm{Y}-0.6912 \cdot \log \mathrm{Ce}-2.014 \cdot \log \mathrm{Eu}+14.84 \cdot \log \mathrm{Dy}-3.946 \cdot \log \mathrm{Yb}-0.734 \cdot \log \mathrm{Th}+$ $2.513 \cdot \log \mathrm{U}+24.20 ; \mathrm{DP} 2-2-3=-0.3009 \cdot \log \mathrm{Mg}-0.078 \cdot \log \mathrm{Mn}-1.591 \cdot \operatorname{logSr}-6.697 \cdot \log \mathrm{Y}-0.6125 \cdot \log \mathrm{Ce}-0.2912 \cdot \log \mathrm{Eu}$ $+0.722 \cdot \log \mathrm{Dy}+2.686 \cdot \log \mathrm{Yb}+1.466 \cdot \log \mathrm{Th}+0.4239 \cdot \log \mathrm{U}+16.26$. c) The first discriminant function $(\mathrm{DP} 2-3-1)$ vs. the second discriminant function (DP2-3-2); DP2-3-1 $=1.034 \cdot \log \mathrm{Mg}-3.069 \cdot \log \mathrm{Mn}+4.045 \cdot \log \mathrm{Y}+3.368 \cdot \log \mathrm{Ce}-3.127 \cdot \log \mathrm{Eu}-$ $0.2322 \cdot \log \mathrm{Dy}-0.7732 \cdot \log \mathrm{Yb}-0.1035 \cdot \log \mathrm{Pb}-1.228 \cdot \log \mathrm{Th}-0.2231 \cdot \log \mathrm{U}-4.263 ; \mathrm{DP} 2-3-2=1.888 \cdot \log \mathrm{Mg}-1.839 \cdot \log \mathrm{Mn}$ $-4.813 \cdot \log \mathrm{Y}-0.3218 \cdot \log \mathrm{Ce}-3.421 \cdot \log \mathrm{Eu}+10.67 \cdot \log \mathrm{Dy}-5.662 \cdot \log \mathrm{Yb}+1.706 \cdot \log \mathrm{Pb}-1.043 \cdot \log \mathrm{Th}+1.803 \cdot \log \mathrm{U}+$ 14.24. Variables are log10-equivalents of element concentrations in ppm for all elements, except for $\mathrm{Mg}$, which is in wt \%.

One possible explanation is that apatite has inherited the positive $\mathrm{Eu}$ anomaly from $\mathrm{K}$-feldspar and/or plagioclase during sericitic alteration of the feldspars. The REE are highly incompatible with micas (Adam and Green, 2006); thus, the coeval apatites would readily accommodate any REE released by feldspar breakdown. Such anomalies are unlikely to be characteristic of orogenic Au deposits, but they could form wherever feldspar breakdown accompanies apatite growth. The apatite in two Seabee samples shows very different trace element contents (Fig. 9; App. Table 4), possibly owing to variations in the redox conditions accompanying gold mineralization in the Seabee deposit (Schultz, 1996; Tourigny, 2003).

The hydrothermal apatites in samples from the Kirkland Lake orogenic $\mathrm{Au}$ deposits contain very high $\mathrm{Mg}$ contents
(969-1,334 ppm), perhaps reflecting their growth during alteration of primary clinopyroxene. Igneous apatites from two unmineralized samples associated with clinopyroxene contain less Mg (generally <200 ppm). Rowins et al. (1991) recognized that the syenitic Murdock Creek intrusion in the Kirkland Lake mining camp formed at an intrinsically high magmatic $f_{\mathrm{O}_{2}}$ that ranged between the nickel-nickel oxide (NNO) and hematite-magnetite (HM) oxygen buffers. Consequently, primary clinopyroxene and biotite have relatively high $\mathrm{Mg} / \mathrm{Fe}$ ratios due to the low $\mathrm{Fe}^{2+} / \mathrm{Fe}^{3+}$ in the magma, which results in the substitution of $\mathrm{Mg}^{2+}$ for $\mathrm{Fe}^{2+}$ in primary ferromagnesian silicates. It can be inferred from petrography that primary clinopyroxene crystallized prior to apatite in the Kirkland Lake magmas, producing relatively low $\mathrm{Mg}$ 

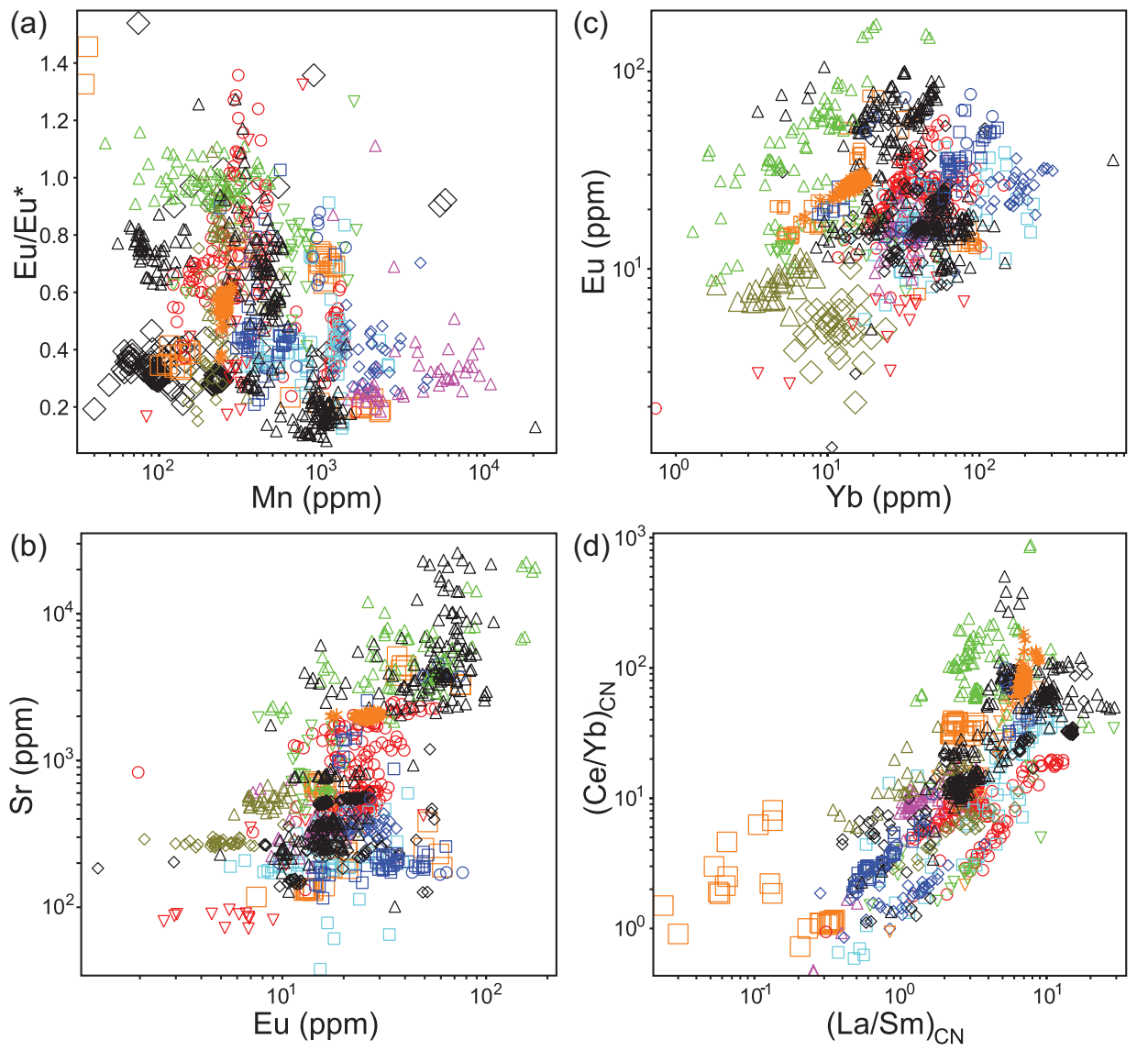

$\triangle$ Carbonatites, phoscorites, and
associated ijolites
$\square$ MOR
$\diamond$ IOCG and Kiruna-type
$\square$ Orogenic $\mathrm{Au}$
$\triangle$ Orogenic Ni-Cu
$\bigcirc$ Epithermal Au-Ag
$\nabla$ Au-Co, Cu, and $\mathrm{Pb}-\mathrm{Zn}$ skarns

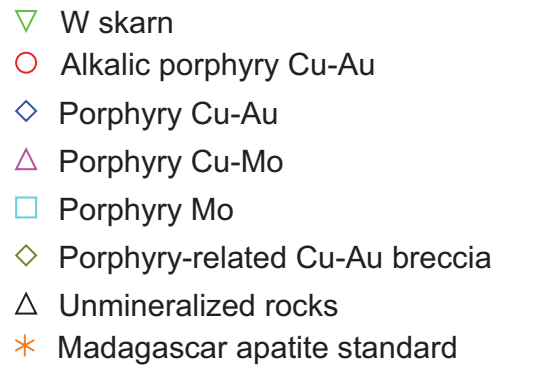

Fig. 9. Scatterplots for apatites. a) $\mathrm{Mn}(\mathrm{ppm})$ vs. $\mathrm{Eu} / \mathrm{Eu}^{*} ; \mathrm{Eu} / \mathrm{Eu}^{*}=\mathrm{Eu}_{\mathrm{CN}} \cdot\left(\mathrm{Sm}_{\mathrm{CN}} \cdot \mathrm{Gd}_{\mathrm{CN}}\right)^{-0.5}$. b) $\mathrm{Eu}(\mathrm{ppm})$ vs. Sr (ppm). c) $\mathrm{Yb}(\mathrm{ppm})$ vs. Eu (ppm). d) (La/Sm $)_{\mathrm{CN}}$ vs. $(\mathrm{Ce} / \mathrm{Yb})_{\mathrm{CN}}$. Larger-size symbols highlight apatites from specific deposits discussed in text.

contents in the apatites. Alteration of the clinopyroxene during the gold mineralization event caused hydrothermal apatite to inherit the Mg-rich nature of the primary clinopyroxene, thereby producing the high $\mathrm{Mg}$ contents of the apatites.

In contrast to the Kirkland Lake Au deposits, which are mid-crustal mesozonal orogenic systems (Rowins et al., 1991; Robert, 2001; Ispolatov et al., 2008), geological features of the Congress (Lou) orogenic Au deposit suggest formation at shallower epizonal depths (e.g., Groves et al., 1998). The Congress (Lou) deposit is hosted in mafic volcanic rocks and the Au-bearing veins consist mainly of stibnite, arsenopyrite, and other sulfide minerals (Harrop and Sinclair, 1986; Schroeter, 1987; Leitch et al., 1989). Interestingly, however, the apatites from Congress (Lou) have $\mathrm{Mg}$ contents and $(\mathrm{La} / \mathrm{Sm})_{\mathrm{CN}}$ and $(\mathrm{Ce} / \mathrm{Yb})_{\mathrm{CN}}$ ratios, and $\mathrm{Eu} / \mathrm{Eu}^{*}$ values similar to those of the Kirkland Lake apatites (Fig. 9a, d). In the case of the Congress deposit, the high $\mathrm{Mg}$ contents of hydrothermal apatites may reflect the mafic protolith.

\section{Discrimination of porphyries and skarns (step IIIa, DP3)}

Discrimination diagrams for this step were constructed using apatite compositions from various porphyry and skarn deposits that were subdivided from the other deposit types in the previous step. To perform the DPA, Mg, Mn, Sr, Y, Ce, Eu, $\mathrm{Yb}, \mathrm{Pb}, \mathrm{Th}$, and U were used (Table 5; App. Table 5).

Most of the apatite compositions from Au-Co skarns, alkalic porphyry $\mathrm{Cu}-\mathrm{Au}$, and porphyry-related $\mathrm{Cu}-\mathrm{Au}$ breccia deposits are discriminated from one another and other types of porphyries and skarns by the first two discriminant functions (Fig. 10a). Although slightly overlapping with the apatite compositions from alkalic porphyry $\mathrm{Cu}-\mathrm{Au}$ deposits, most of the apatites from porphyry Mo and porphyry $\mathrm{Cu} \pm$ 
(a)

(b)
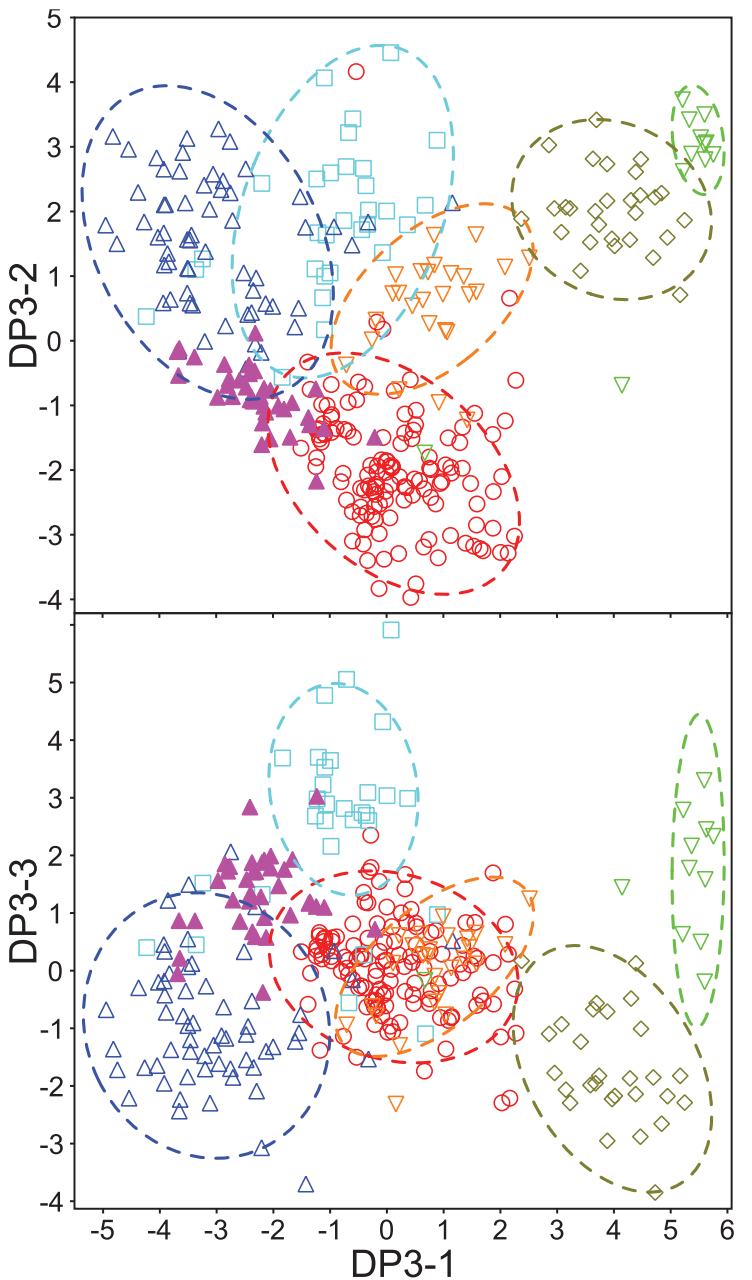

$\bigcirc$ Alkalic porphyry Cu-Au

$\triangle$ Porphyry Cu \pm Mo $\pm \mathrm{Au}$

Porphyry Mo

$\diamond$ Porphyry-related Cu-Au breccia

$\nabla$ Au-Co, $\mathrm{Cu}$, and $\mathrm{Pb}-\mathrm{Zn}$ skarns

$\nabla$ W skarn

\section{Literature data: $\Delta$ Porphyry $\mathrm{Cu}-\mathrm{Mo}$}

Fig. 10. Discrimination diagrams for apatites from different porphyry and skarn deposits, showing contours of constant Mahalanobis distance outlining bulk of the data in each group (step IIIa; Table 5; App. Table 5). Also shown are literature data (Cao et al., 2012) that were not used in DPA for construction of the discrimination diagrams. a) The first discriminant function (DP3-1) vs. the second discriminant function (DP3-2). b) The first discriminant function (DP3-1) vs. the third discriminant function (DP3-3). DP3-1 = $0.8718 \cdot \log \mathrm{Mg}-4.156 \cdot \log \mathrm{Mn}-3.065 \cdot \operatorname{logSr}+6.341 \cdot \log \mathrm{Y}-1.704 \cdot \log \mathrm{Ce}-$ $1.806 \cdot \log \mathrm{Eu}-7.320 \cdot \log \mathrm{Yb}-0.2802 \cdot \log \mathrm{Pb}+0.6948 \cdot \log \mathrm{Th}+1.698 \cdot \log \mathrm{U}+$ $21.07 ; \mathrm{DP} 3-2=-1.473 \cdot \log \mathrm{Mg}+2.550 \cdot \log \mathrm{Mn}-2.981 \cdot \log \mathrm{Sr}-5.398 \cdot \log \mathrm{Y}+$ $0.5600 \cdot \log \mathrm{Ce}-2.898 \cdot \log \mathrm{Eu}+3.780 \cdot \log \mathrm{Yb}+2.108 \cdot \log \mathrm{Pb}-0.4108 \cdot \log \mathrm{Th}-$ $0.1375 \cdot \log \mathrm{U}+8.534 ; \mathrm{DP} 3-3=0.1617 \cdot \log \mathrm{Mg}-1.173 \cdot \log \mathrm{Mn}-4.364 \cdot \log \mathrm{Sr}$ $+2.634 \cdot \log \mathrm{Y}+0.8452 \cdot \log \mathrm{Ce}+3.378 \cdot \log \mathrm{Eu}-3.184 \cdot \log \mathrm{Yb}+1.619 \cdot \log \mathrm{Pb}+$ $1.956 \cdot \log \mathrm{Th}-0.6212 \cdot \log \mathrm{U}+4.471$. Variables are $\log 10$-equivalents of element concentrations in ppm for all elements, except for $\mathrm{Mg}$, which is in wt \%.

$\mathrm{Mo} \pm \mathrm{Au}$ (this includes both porphyry $\mathrm{Cu}-\mathrm{Au}$ and porphyry Cu-Mo subtypes) are distinguished from other deposit types in the DP3-1 vs. DP3-3 space (Fig. 10b). Apatites from W skarns partly overlap with apatites from porphyry Mo deposits in DP3-1 vs. DP3-2 space (Fig. 10a), but they are separated effectively from each other in DP3-1 vs. DP3-3 space (Fig. 10b). The separation between these apatite groups is better illustrated in 3-D in terms of the DP3-1, DP3-2, and DP3-3 axes (App. Movie 2).

The apatites from the three alkalic porphyry $\mathrm{Cu}-\mathrm{Au}$ deposits studied here (Dobbin, Mount Polley, Shiko) are characterized by very high $\mathrm{V}(<3-337 \mathrm{ppm}$; Table 4; Fig. 11a), high Sr $(131-2,488 \mathrm{ppm})$, and detectable Si $(<0.05-0.43$ wt \%) and $\mathrm{S}(<0.08-0.45 \mathrm{wt} \%)$ contents, and a wide range of $\mathrm{Ce} /$ $\mathrm{Ce}^{*}(0.87-1.71)$. This distinguishes them from apatites in the other deposit types. The elevated $\mathrm{V}$ and $\mathrm{S}$ contents, coupled with the relatively low Mn contents (122-1,611 ppm; Table 4) of these apatites, probably indicate crystallization in an oxidizing environment (Sha and Chappell, 1999; Belousova et al., 2002). The correlated Si and S contents likely indicate their coupled substitution (eq. 6). Textural relationships and mineral assemblages (App. Table 1) suggest that apatites sampled in the alkalic porphyry $\mathrm{Cu}-\mathrm{Au}$ deposits are both magmatic and hydrothermal in origin because all of these rocks experienced some late-stage hydrothermal alteration (e.g., Richards, 1990). Vanadium, as $\mathrm{V}^{3+}$ and $\mathrm{V}^{4+}$, partitions preferentially into magmatic magnetite, clinopyroxene, hornblende, and biotite, but is released during late-stage alteration and can be incorporated by apatites as $\mathrm{V}^{5+}$ under oxidizing conditions (Luhr and Carmichael, 1980; Bea et al., 1994; Canil and Fedorchouk, 2000; Toplis and Corgne, 2002). $\mathrm{SO}_{4}^{2-}$ may also act as a complexing agent during alteration (Parsapoor et al., 2009), and may be incorporated by apatites. Thus, the high V and $\mathrm{S}$ contents, coupled with the variation in $\mathrm{Ce} / \mathrm{Ce}^{*}$ in apatites from alkalic porphyry $\mathrm{Cu}-\mathrm{Au}$ deposits, probably reflect oxidizing conditions prevailing during both magma evolution and deposit formation.

The calc-alkaline porphyry $\mathrm{Cu} \pm \mathrm{Mo} \pm \mathrm{Au}$ deposits in this study include one porphyry $\mathrm{Cu}-\mathrm{Au}$ deposit (Kemess South) and four porphyry Cu-Mo deposits (Gibraltar, Highmont, Highland Valley Copper, and Lornex), which all share similar lithologies, alteration, and mineral assemblages. Furthermore, because apatites from these deposits share many trace element characteristics (Fig. 9), they are discussed together. These apatites have very high Mn (334-10,934 ppm) and relatively low $\mathrm{Sr}$ (186-904 ppm) contents, and generally very strong negative $\mathrm{Eu}$ anomalies $\left(\mathrm{Eu} / \mathrm{Eu}^{*}=0.18-1.11\right.$, averaging 0.36; Fig. 9a, b). Apatites from the Kemess South porphyry $\mathrm{Cu}-\mathrm{Au}$ deposit can be identified by their high HREE contents such as $\mathrm{Yb}$ (Fig. 11b), but more data are needed to determine if this is a general characteristic of all porphyry $\mathrm{Cu}-\mathrm{Au}$ deposits.

Studies on porphyry $\mathrm{Cu} \pm \mathrm{Mo} \pm \mathrm{Au}$ deposits have shown that mineralization is mainly hosted by potassically ( $\mathrm{K}$-feldspar and/or biotite) and phyllically (quartz-sericite) altered quartz monzonite to granodiorite compositions (McMillian, 1976; Olade and Fletcher, 1976; Ash and Riveros, 2001; Duuring et al., 2009b). These studies have found gradually decreasing whole-rock $\mathrm{Mn}$ and $\mathrm{Sr}$ contents from the edge of the ore zone to the core of orebody, coincident with the potassic and phyllic alteration zones. These trends of the $\mathrm{Mn}$ and $\mathrm{Sr}$ depletion in ore zones were attributed to the hydrothermal breakdown of plagioclase and ferromagnesian minerals to sericite, quartz, epidote, and chlorite (e.g., Olade and Fletcher, 1976; Ash and Riveros, 2001; Duuring et al., 2009b). Since apatites incorporate $\mathrm{Mn}^{2+}$ more readily than $\mathrm{Mn}^{3+}$ or $\mathrm{Mn}^{4+}$, they tend to be relatively $\mathrm{Mn}$ poor in oxidizing environments (Miles et al., 

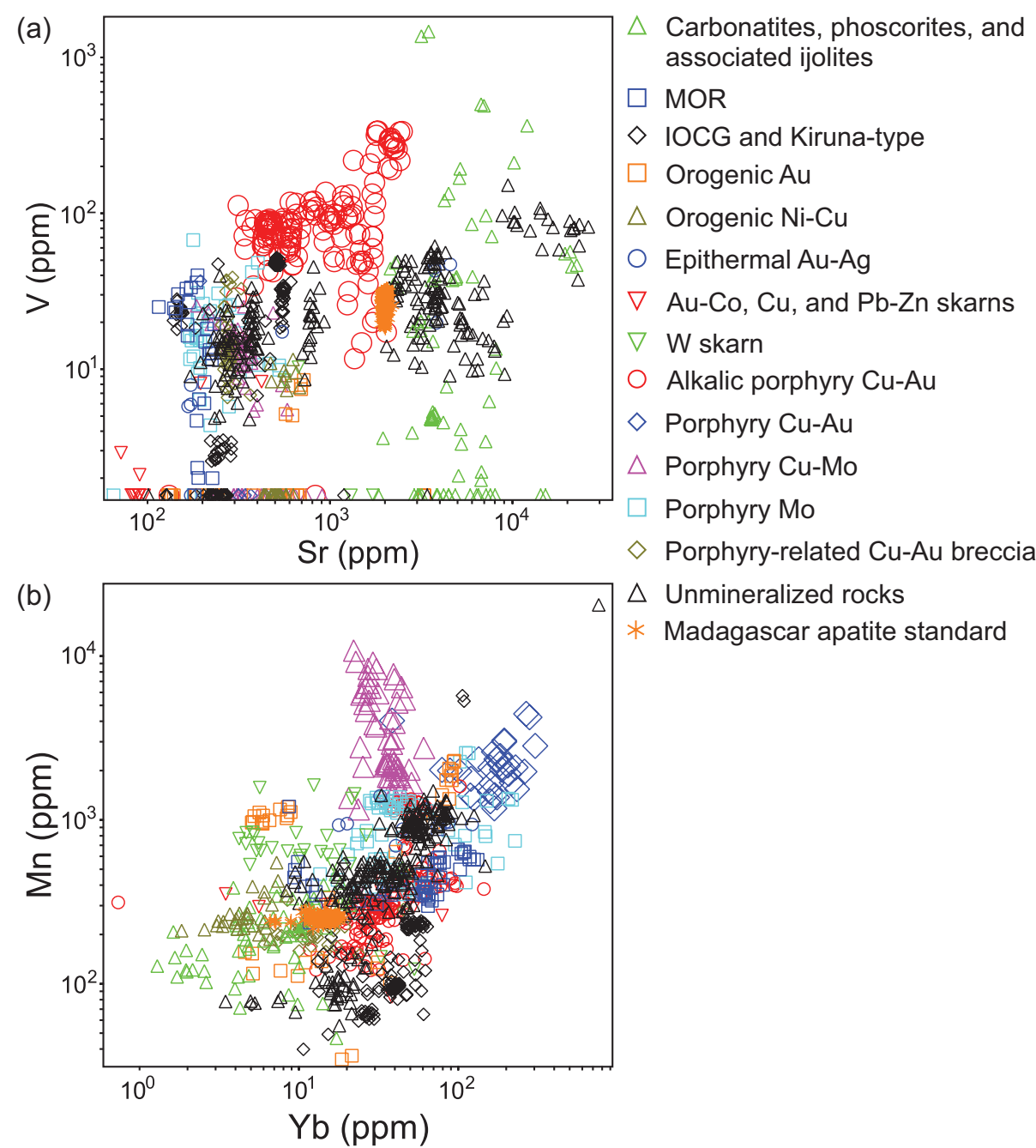

Fig. 11. Scatterplots for apatites. a) $\mathrm{Sr}$ (ppm) vs. V (ppm). b) Yb (ppm) vs. Mn (ppm). Larger-size symbols represent apatites from specific deposits discussed in text.

2014). Some redox control over apatite Mn contents is consistent with the porphyry deposits in this study, where alkalic porphyry $\mathrm{Cu}-\mathrm{Au}$ deposits, the most oxidized of all the porphyry deposit types (e.g., Lang et al., 1995), have the lowest Mn contents. Strontium contents of apatites, unlike Mn contents, are more likely to mimic those of whole rocks due to the different site preferences for $\mathrm{Sr}$ and $\mathrm{Mn}$ in apatites (Piccoli and Candela, 2002). The relatively low $\mathrm{Sr}$ contents in these apatites are consistent with the Sr depletion in the ore zones (Olade and Fletcher, 1976). The large variations in the size of negative Eu anomalies (Fig. 9a) may reflect early plagioclase fractionation or partial melting of source rocks that retained feldspar (Watson and Green, 1981; Piccoli and Candela, 2002; Tollari et al., 2008).

Apatites from porphyry-related $\mathrm{Cu}-\mathrm{Au}$ breccia show some of the lowest abundances of most trace elements in this study (Fig. 3a). They can be discriminated from other groups using $\mathrm{Sr}, \mathrm{Eu}$, and $\mathrm{Yb}$ (Fig. 9b, c) and their relatively high As (17$419 \mathrm{ppm})$ and $\mathrm{W}(<1-10 \mathrm{ppm})$ contents (Table 4$)$. The very low impurity cation contents of apatites from the porphyryrelated $\mathrm{Cu}-\mathrm{Au}$ breccia deposit are consistent with apatite crystallization from relatively low temperature fluids where cation mobility was restricted. Subsequent calcic alteration associated with the $\mathrm{Au}-\mathrm{Cu}-\mathrm{Ag}$ mineralization may have exchanged $\mathrm{Ca}^{2+}$ for impurity cations in these apatites.

Apatites from Au-Co skarn deposits (Minyari, Australia, and Racine, British Columbia) typically contain the lowest $\mathrm{Sr}$ and Eu contents (Table 4, Fig. 9b) found in this study. The low contents of cation impurities, especially LREE, are similar to those of apatites from Wernecke IOCG breccia and porphyryrelated $\mathrm{Cu}-\mathrm{Au}$ breccia. Most $\mathrm{Au}( \pm \mathrm{Co}$ ) skarns are hosted by calcareous rocks and metasomatic fluids in the contact zone are Ca rich (e.g., Ray, 1998). Based on crystal chemistry, apatites formed from a Ca-rich but Sr- and REE-poor fluid at a relatively low temperature will tend to have low abundances of trace elements that include Sr.

\section{Discrimination of IOCG and Kiruna-type deposits (step IIIb, DP4)}

The discrimination diagrams for this step were constructed using apatite data from the Wernecke IOCG breccia and Kiruna-type deposits. These diagrams (Fig. 12), therefore, are 


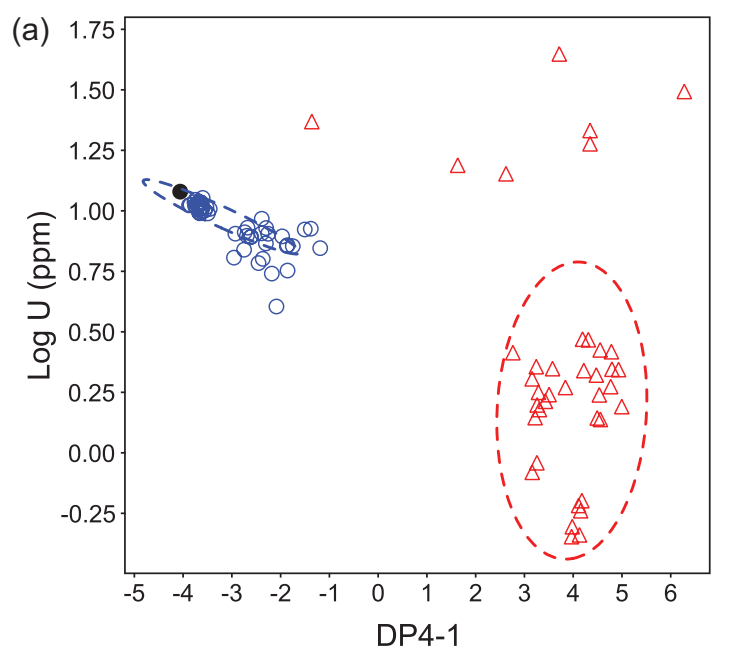

(b)

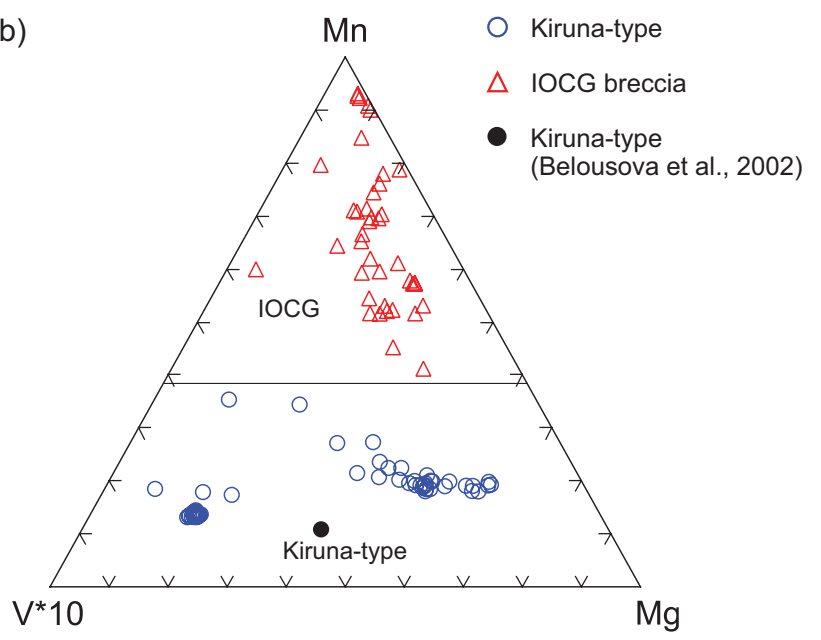

Fig. 12. Discrimination diagrams for apatites from IOCG deposits. Also shown is the median apatite from Kiruna-type IOCG deposits (Belousova et al., 2002) that was not used in DPA for construction of the discrimination diagrams. a) The first discriminant function (DP4-1) vs. $\log \mathrm{U}(\mathrm{ppm})$, showing contours of constant Mahalanobis distance outlining bulk of the data in each group (step IIIb; Table 5; App. Table 5); DP4-1 = 5.379 $\log \mathrm{V}+$ $1.0285 \cdot \log \mathrm{Mn}+1.0004 \cdot \log \mathrm{Sr}-0.0447 \cdot \log \mathrm{Ce}+3.169 \cdot \log \mathrm{Eu}-5.412 \cdot \log \mathrm{Yb}$ $-0.3302 \cdot \log \mathrm{Pb}-0.1080 \cdot \log \mathrm{Th}+5.385$; variables are $\log 10$-equivalents of element concentrations in ppm. b) $\mathrm{Mg}-\mathrm{V} \cdot 10-\mathrm{Mn}$ (ppm) ternary plot, showing boundary between apatites from breccia- and Kiruna-type IOCG deposits.

intended for use with samples determined to have an IOCG or Kiruna-type affinity at step II. The concentrations of V, Mn, $\mathrm{Sr}, \mathrm{Ce}, \mathrm{Eu}, \mathrm{Yb}, \mathrm{Pb}$, and Th have been used in the DPA calculation (Table 5, App. Table 5) to separate these deposits into the IOCG breccia-type and Kiruna-type groups.

Apatites from the subduction-related Kiruna-type deposits tend to have more restricted compositions than those from the postorogenic Wernecke IOCG breccias. The latter have higher $\mathrm{Mn}$ concentration at the same $\mathrm{V}$ and $\mathrm{Mg}$ concentrations (Fig. 12b) and a much wider range of $\mathrm{Eu} / \mathrm{Eu}^{*}$ values $(0.3-1.5)$ than the former $\left(\mathrm{Eu} / \mathrm{Eu}^{*}=0.2-0.4\right)$. Apatites from Kiruna-type deposits have relatively high LREE, $\mathrm{Na}, \mathrm{Si}$, and $\mathrm{S}$ contents (Table 4) which are correlated as charge compensators (Fig. 3c). The low Ca contents of apatites from Kirunatype deposits are close to those of apatites from unmineralized rocks (Fig. 2). In contrast, apatites from the Wernecke IOCG breccia deposit generally have higher Ca contents and correspondingly lower abundances of impurity cations, although some apatite grains have much higher $\Sigma$ LREE contents $(14,872-19,050 \mathrm{ppm})$ than those of apatite from Kiruna-type deposits (171-9,582 ppm). Light rare-earth elements are abundant in many Kiruna-type and IOCG deposits, although not always at economic levels (Hitzman et al., 1992; Sillitoe, 2003; Mao et al., 2008). The typical mineral assemblage for Kiruna-type deposits is magnetite \pm actinolite \pm apatite with apatite serving as the main repository for the REEs.

Apatites from some Kiruna-type deposits (Cerro de Mercado and Great Bear) have the highest As contents (929$2,251 \mathrm{ppm}$ ) measured in this study. Arsenic is typically sourced from (meta)sedimentary rocks (Lollar, 2004), where it accumulates during the weathering cycle (Cornett et al., 1992). Consequently, an ore-forming fluid passing through (meta)sedimentary rocks may liberate As and make it available for incorporation into later forming minerals such as apatite. The geologic setting of the Cerro de Mercado and Great Bear deposits is consistent with this explanation (e.g., Mumin et al., 2007; Rakovan, 2007; Acosta-Góngora et al., 2014). The high As contents (up to $506 \mathrm{ppm}$; Table 4) in some apatites from the Wernecke IOCG breccia deposit are also consistent with its formation in a Proterozoic metasedimentary basin. In contrast, apatite from the Aoshan Kiruna-type deposit has much lower As contents (<332 ppm). Other deposit types with elevated As contents in apatites include the Seabee orogenic Au deposit (up to 1,079 ppm As; Table 4) and some alkalic porphyry $\mathrm{Cu}-\mathrm{Au}$ and porphyry-related $\mathrm{Cu}-\mathrm{Au}$ breccia deposits (up to $879 \mathrm{ppm}$ As). The variability of As abundances in apatite suggests that elevated As is probably a good local indicator of $\mathrm{Au}$ and/or $\mathrm{Cu}$ mineralization, but is not specific to a deposit type.

\section{Classification of literature data from known deposits}

The discrimination approach developed in this study was tested by applying it to published apatite compositions of known affinity that were not used in developing the approach described above (Belousova et al., 2002; Cao et al., 2012). The apatite data from Belousova et al. (2002) are median apatite compositions from carbonatites (Fen, Kovdor, Mud Tank, and Phalaborwa), Kiruna-type deposits (Kiruna and Cerro de Mercado), granite pegmatites (5 occurrences from Norway), and unmineralized syenites (Oslo Rift) and dolerite (Crimea Mountains). Note that Durango apatite (Cerro de Mercado) was used to calibrate the approach, but due to the paucity of apatite analyses in the literature, we still used the median value based on this apatite. The apatite data from Cao et al. (2012) are from the Aktogai porphyry $\mathrm{Cu}-\mathrm{Mo}$ deposit and an unmineralized batholith.

Using the discriminant functions DP1-1 vs. DP1-2 (step I; Table 5), most of the literature data are correctly classified. The median carbonatite falls within the carbonatite field and the porphyry $\mathrm{Cu}-\mathrm{Mo}$ and Kiruna-type data points all fall within the mineralized apatite contour. The unmineralized batholith apatite also falls within the unmineralized field (Fig. 7a). The published apatite compositions for barren syenites and dolerite fall within the mineralized field, overlapping our data from MOR, in the DP1-1 vs. DP1-2 diagram (Fig. 7a). They are separated from the mineralized systems in the log 
Sr vs. $\log \mathrm{Zr}$ diagram (Fig. 7b), consistent with their mafic parental magmas (Belousova et al., 2002). The median apatite composition for several Norwegian granite pegmatites, including Li-rich, tourmaline-bearing type, also falls within the mineralized field in Figure 7a and b, reflecting the hydrothermal origin of these apatite megacrysts (Belousova et al., 2002). Only the published data from the Kiruna-type and porphyry $\mathrm{Cu}-\mathrm{Mo}$ deposits are projected into the discrimination diagrams for various deposit types (steps II and III).

In terms of the discriminant functions for general deposit types (DP2-1-1 vs. DP2-1-2, DP2-2-2 vs. DP2-2-3, and DP23-1 vs. DP2-3-2; step II; Table 5), the published data from porphyry $\mathrm{Cu}-\mathrm{Mo}$ and Kiruna-type deposits plot within their corresponding fields (Fig. 8). However, where projected using the discriminant functions for porphyries and skarns (DP3-1 vs. DP3-2 and DP3-1 vs. DP3-3; Table 5), only about half of the data from the porphyry $\mathrm{Cu}-\mathrm{Mo}$ deposit are classified correctly as apatite from a porphyry $\mathrm{Cu} \pm \mathrm{Mo} \pm \mathrm{Au}$, with a few data points falling within the alkalic porphyry $\mathrm{Cu}-\mathrm{Au}$ field and the rest of the data straddling the boundary between the porphyry $\mathrm{Cu} \pm \mathrm{Mo} \pm \mathrm{Au}$ and the porphyry Mo fields (Fig. 10). It should be noted that apatite from the Aktogai porphyry $\mathrm{Cu}-\mathrm{Mo}$ deposit has a lower Mn content than apatite from five porphyry $\mathrm{Cu} \pm \mathrm{Mo} \pm \mathrm{Au}$ deposits in this study (Table 2 ). This difference may be due to different analytical methods, which were EMPA in Cao et al. (2012) and LA-ICPMS in this study. Since $\mathrm{Mn}$ is an important contributor to the discriminant functions DP3-1 and DP3-2 (App. Table 5), the difference in Mn contents may explain the partial misclassification of the data in Fig. 10. Despite this discrepancy, much of the apatite data from the Aktogai porphyry Cu-Mo deposit are still correctly classified in these discrimination diagrams.

A plot of the discriminant function DP4-1 (step IIIb; Table 5) vs. $\log \mathrm{U}$ content and a ternary Mg-V-Mn plot for separating IOCG and Kiruna-type deposits correctly classify the median Kiruna and Cerro de Mercado apatite composition of Belousova et al. (2002) as a Kiruna-type (Fig. 12). Although little trace element data were available on apatite from Kiruna-type deposits, our results demonstrate that apatite trace element chemistry has the potential to discriminate between Kiruna-type and IOCG deposits. Future work should test this finding by analyzing apatites from world-class IOCG deposits such as Olympic Dam, Candelaria, Carajás, Cloncurry, as well as other Kiruna-type deposits from Sweden and northern Chile.

The correct identification of these published apatite data in step I, step II, and step IIIb indicates that the discriminant diagrams/functions are capable of classifying unknown apatite grains according to their unmineralized/mineralized origins and primary deposit types. Thus, the trace element compositions of detrital apatite in sedimentary overburden (e.g., stream sediments, tills, etc.) can be used as a robust new tool for mineral exploration. The proposed discrimination diagrams do require further testing with apatite data from known deposits. As the body of literature with high-quality apatite trace element data continues to grow, the discrimination diagrams may be refined by new DPA. Presently, carbonatites are the most robustly discriminated deposit type in our study because apatites come from many complexes worldwide. The porphyry $\mathrm{Cu}-\mathrm{Mo}-\mathrm{Au}$ deposit types are also robustly discriminated because a relatively large number of samples from numerous individual deposits were examined, albeit all from British Columbia. A few deposit types (e.g., orogenic $\mathrm{Ni}-\mathrm{Cu} \pm \mathrm{PGE}$ ), however, are based on samples from a single locality and thus their fields in the discrimination diagrams are not as robust as others. We note, however, that these apatite discrimination diagrams are best used in conjunction with other available data including regional geochemistry, geophysics, other indicator minerals, ice-flow history, and local geology in confirming deposit types.

\section{Conclusions}

In this study we analyzed the trace element compositions of apatite grains (922 analyses) from most major types of mineral deposits by LA-ICPMS and constructed optimized discrimination diagrams from DPA using the multi-element data set. The calculated discriminant functions highlight distinct trace element differences between apatites from barren rocks and the different deposit types. In general, the discrimination diagrams successfully predicted known deposit-type affinities of apatites from previous studies. The discrimination of apatites from the different deposits relies on the multivariate DPA approach because trace element contents of apatites show large variations owing to many controlling factors, including fluid/melt source variation, degree of fractionation, crystallization history, coexisting mineral assemblage, alteration types, and redox conditions. Even for individual deposit types where apatites displayed significant variation in trace element contents, the linear discriminant functions derived from the multivariate data successfully minimized differences between the data within the same deposit group while enhancing the contrast between the groups. Moreover, scaled contributions from individual variables identify critical elements in discriminating apatites from different deposits, which may not be otherwise apparent from the multi-element data.

Through the four discrimination steps, the apatites from many ore deposits can be readily separated from the other groups. Specifically, step I draws three distinct groups for apatites from carbonatites, ore deposits, and unmineralized rocks (Fig. 7a). Those apatites from barren MOR and (grano) dioritic rocks in an overlapped area between ore deposits and unmineralized rocks can be further separated by Sr, $\mathrm{Zr}$, and $\mathrm{Cl}$ contents and $\mathrm{Eu}$ anomalies (Fig. 7b, c). Within different ore deposits, apatites from orogenic $\mathrm{Au}$, orogenic $\mathrm{Ni}-\mathrm{Cu} \pm \mathrm{PGE}$, and undivided Kiruna-type and IOCG deposits stand out from other types of deposits in step II (Fig. 8), and the apatites determined to have iron oxide-associated affinity at this step are further subdivided into Kiruna-type and IOCG breccia-type deposits in step IIIb (Fig. 12). Apatites classified as having porphyry or skarn affinities at step II are further successfully discriminated into alkalic porphyry $\mathrm{Cu}-\mathrm{Au}$, porphyry $\mathrm{Cu} \pm \mathrm{Mo} \pm \mathrm{Au}$, porphyry Mo, porphyryrelated $\mathrm{Cu}-\mathrm{Au}$ breccia, and $\mathrm{Au}-\mathrm{Co}$ skarn deposits, with most of the apatites from W skarn deposits separated by elimination of other deposit types in these discriminant-function diagrams (Fig. 10).

Hydrothermal apatites in mineralized rocks generally contain relatively low concentrations of elements that partition onto the Ca sites due to relatively low crystallization temperatures and resultant decreased mobility of impurity elements. 
The main trace element characteristics of apatites from different deposit types are as follows:

1. Apatites from carbonatites are characterized by the highest Si $(<0.05-1.30$ wt \%), V (<1.6-1,466 ppm), Ba (1.8$275 \mathrm{ppm}), \mathrm{Nb}(<0.4-19 \mathrm{ppm})$, high Sr $(1,840-22,498$ $\mathrm{ppm})$, and the lowest $\mathrm{W}(<0.05-0.55 \mathrm{ppm})$ contents. They exhibit strongly LREE enriched REE distribution (Ce/ $\left.\mathrm{Yb}_{\mathrm{CN}}=35-872\right)$, with moderate positive Ce anomalies $(\mathrm{Ce} /$ $\left.\mathrm{Ce}^{*}=1.0-1.7\right)$ and lack Eu anomalies $\left(\mathrm{Eu} / \mathrm{Eu}^{*}=0.9-1.2\right)$. The very high Sr, LREE, V, Ba, and Nb contents in apatites are attributed to the high abundances of these elements in carbonate melts and related fluids. Silicon, along with $\mathrm{S}$ and $\mathrm{Na}$, is present as charge compensators. High $\mathrm{Nb}$, coupled with low $\mathrm{W}$ contents, is diagnostic of carbonatitic apatites.

2. Apatites from alkalic porphyry $\mathrm{Cu}-\mathrm{Au}$ deposits have high $\mathrm{V}$ $(<2.5-337 \mathrm{ppm})$ and $\mathrm{S}(<0.08-0.45$ wt \%) contents. They show the widest range of $\mathrm{Ce} / \mathrm{Ce}^{*}(0.9-1.7)$ of all apatite groups, consistent with high but variable redox conditions during their formation.

3. Apatites from porphyry $\mathrm{Cu} \pm \mathrm{Mo} \pm \mathrm{Au}$ deposits show very high Mn contents (334-10,934 ppm) and variable, but generally strongly negative, Eu anomalies $\left(\mathrm{Eu} / \mathrm{Eu}^{*}=0.2-1.1\right.$, averaging 0.4 ). The high $\mathrm{Mn}$ contents are probably related to Mn-rich fluid responsible for phyllic alteration.

4. Apatites from Kiruna-type deposits have the highest $\mathrm{Na}$ $(<0.07-0.37$ wt \%) and S $(<0.08-0.49$ wt \%), and lowest $\mathrm{Mn}(40-245 \mathrm{ppm})$ contents, and display strong negative $\mathrm{Eu}$ anomalies $\left(\mathrm{Eu} / \mathrm{Eu}^{*}=0.2-0.4\right)$. The low $\mathrm{Mn}$ contents are interpreted to be due to the coexisting actinolite and magnetite, both of which incorporate $\mathrm{Mn}$. The strong negative $\mathrm{Eu}$ anomalies probably reflect crystallization of K-feldspar during early-stage potassic alteration. The high $\mathrm{Na}$ and $\mathrm{S}$ contents correlate with relative enrichment in LREE as charge compensators.

5. Compared with Kiruna-type apatites, most apatites from the Wernecke IOCG breccia contain higher Mn and lower LREE, $\mathrm{Na}, \mathrm{Mg}, \mathrm{Si}$, and $\mathrm{S}$ contents. Apatites from Wernecke IOCG breccia also show much higher $\mathrm{Eu} / \mathrm{Eu}^{*}(0.3-$ 1.5) than those from Kiruna-type deposits. These apatites, along with those from porphyry-related $\mathrm{Cu}-\mathrm{Au}$ breccia deposit, tend to have relatively low contents of impurity cations compared with apatites from other deposit types, perhaps reflecting the lower formation temperatures of these deposits.

6. The high As contents found in some apatites from Kirunatype (up to 2,251 ppm), orogenic Au (up to 1,079 ppm), and other deposit types are interpreted to relate to a (meta) sedimentary source and may indicate $\mathrm{Au}$ and/or $\mathrm{Cu}$ mineralized systems, but are not specific to a particular deposit type.

This study demonstrates that the trace element contents of natural apatites possess enough variability to accurately determine their igneous source rocks and/or the type of deposit from which they were derived. The study focused on the Canadian Cordillera, where the complex geology has produced an extraordinarily diverse spectrum of ore deposit types making it an ideal natural laboratory in which to study apatites and their host rocks. Therefore, we see no reason why the proposed discrimination approach should not work globally in addition to being a particularly useful exploration tool in glaciated terrains of the North American Cordillera. Finally, despite the large size of the dataset reported here (n = 922, not including analyses from Durango and Madagascar apatites), some apatite-bearing source rocks have either not been analyzed or have few analytical data. Additional work targeting these rocks will help to refine and further test the novel approaches developed in this study.

\section{Acknowledgments}

We thank Martin Reich (University of Chile) and John Hanchar (Memorial University of Newfoundland) for insightful journal reviews that helped to improve the manuscript. Kathy Gillis (University of Victoria), Bobbie John (University of Wyoming), Graham Nixon (British Columbia Geological Survey), Yuanming Pan (University of Saskatchewan), and Stuart Thomson (University of Arizona) are thanked for the loan of apatite samples, and Mingjian Cao (Institute of Geology and Geophysics, Chinese Academy of Sciences) and Guangming Li (Institute of Geology and Geophysics, Chinese Academy of Sciences) for generous sharing of apatite data from the Aktogai porphyry Cu-Mo deposit and an unmineralized batholith. We also thank Edith Czech (UBC) and Mati Raudsepp (UBC) for their assistance with EMPA. Helpful discussions on porphyry deposits and apatite chemistry with André Panteleyev (XDM Geo Consulting) and Yuanming Pan are appreciated. This research was supported by a grant from the BC Ministry of Energy and Mines-University of Victoria Geoscience Partnership Program.

\section{REFERENCES}

Acosta-Góngora, P., Gleeson, S.A., Samson, I.M., Ootes, L. and Corriveau, L., 2014, Trace element geochemistry of magnetite and its relationship to $\mathrm{Cu}-\mathrm{Bi}-\mathrm{Co}-\mathrm{Au}-\mathrm{Ag}-\mathrm{U}-\mathrm{W}$ mineralization in the Great Bear magmatic zone, NWT, Canada: Economic Geology, v. 109, p. 1901-1928.

Adam, J., and Green, T., 2006, Trace element partitioning between mica- and amphibole-bearing garnet lherzolite and hydrous basanitic melt: 1. Experimental results and the investigation of controls on partitioning behavior: Contributions to Mineralogy and Petrology, v. 152, p. 1-17.

Ani, T.A., and Sarapää, O., 2009, Rare earth elements and their mineral phases in Jammi carbonatite veins and fenites on the south side of Sokli carbonatite complex, NE Finland: Geological Survey of Finland, Archive code: M19/4723/2009/34.

Ash, C.H., and Riveros, C.P., 2001, Geology of the Gibraltar copper-molybdenum deposit, east-central British Columbia (93B/9): British Columbia Ministry of Energy and Mines, British Columbia Geological Survey Paper 2001-1, Geological Fieldwork 2000, p. 119-134.

Ash, W.M., and Makepeace, D.K., 2012, Technical report on the Willa deposit Slocan mining district, British Columbia, Canada for Discovery Ventures Inc., <URL: http://www.discoveryventuresinc.com/i/pdf/130223A_Technical_Report_on_the_Willa_Deposit_Jan_23a.pdf> (accessed in November 2014).

Averill, S.A., 2001, The application of heavy indicator mineralogy in mineral exploration with emphasis on base metal indicators in glaciated metamorphic and plutonic terrains: Drift exploration in glaciated terrains, Geological Society, London, Special Publications, v. 185, p. 69-81.

Barley, M.E., and Groves, D.I., 1992, Supercontinent cycle and the distribution of metal deposits through time: Geology, v. 20, p. 291-294.

Barr, D.A., Fox, P.E., Northcote, K.E., and Preto, V.A., 1976, The alkaline suite porphyry deposits: A summary, in Sutherland Brown, A.E., ed., Porphyry deposits of the Canadian Cordillera: Canadian Institute of Mining and Metallurgy Special Volume 15, p. 359-367.

Barton, M.D., and Johnson, D.A., 1996, Evaporitic-source model for igneous-related $\mathrm{Fe}$ oxide-(REE-Cu-Au-U) mineralization: Geology, v. 24 p. 259-262. 
Baumer, A., Caruba, R., Bizzouard, H., and Peckett, A., 1983, Chlorapatite de synthésis: substitution et inclusions de Mn, Ce, U et Th traces: Canadian Mineralogist, v. 21, p. 567-573.

Bea, F., Pereira, M.D., and Stroh, A., 1994, Mineral/leucosome trace-element partitioning in a peraluminous migmatite (a laser ablation-ICP-MS study): Chemical Geology, v. 117, p. 291-312.

Bell, K., ed., 1989, Carbonatites: Genesis and evolution: London, Unwin Hyman, $618 \mathrm{p}$.

Bell, K., 2005, Igneous rocks; carbonatites, in Selley, R.C., Cocks, L.R.M., and Plimer, I.R., eds., Encyclopedia of Geology, v. 3: Oxford, U.K., Elsevier, p. 217-233.

Bell, K., Kjarsgaard, B.A., and Simonetti, A, 1998, Carbonatites-into the $21^{\text {st }}$ century: Journal of Petrology, v. 39, p. 1839-1845.

Belousova, E.A., Walters, S., Griffin, W.L., and O'Reilly, S.Y., 2001, Trace element signatures of apatite from granitoids of Mount Isa inlier, northwestern Queensland: Australian Journal of Earth Sciences, v. 48, p. 603-619.

Belousova, E.A., Griffin, W.L., O'Reilly, S.Y., and Fisher, N.I., 2002, Apatite as an indicator mineral for mineral exploration: Trace-element compositions and their relationship to host rock type: Journal of Geochemical Exploration, v. 76, p. 45-69.

Bigot, L., and Jebrak, M., 2015, Gold mineralization at the Beattie syenitehosted gold deposit, Duparquet, Neoarchean Abitibi belt, Canada: Economic Geology, v. 110 , p. $315-335$.

Binder, G., and Troll, G., 1989, Coupled anion substitution in natural carbon-bearing apatite: Contributions to Mineralogy and Petrology, v. 101, p. 394-401.

Bouzari, F., Hart, C.J.R., Barker, S., and Bissig, T., 2011, Exploration for concealed deposits using porphyry indicator minerals (PIMs): Application of apatite texture and chemistry: 25th International Applied Geochemistry Symposium, Rovaniemi, Finland, August 22-26, 2011, Outokumpu, Finland, Vuorimiesyhdistyksen Tutkimusseloste, Programme and Abstracts, Sarja B, v. 92-1, p. 89-90.

Brookes, M., Baker, T., and Hunt, J., 2001, Alteration zonation, veining and mineralization associated with the Wernecke breccias at Slab Creek, Yukon Territory, Canada: Yukon Exploration and Geology 2001, p. 249-258.

Bühn, B., Wall, F., and Le Bas, M.J., 2001, Rare-earth element systematics of carbonatitic fluorapatites, and their significance for carbonatite magma evolution: Contributions to Mineralogy and Petrology, v. 141, p. 572-591.

Campbell, N.A., 1980, Robust procedures in multivariate analysis I: Robust covariance estimation: Journal of the Royal Statistical Society. Series C, v. 29 , p. $231-237$

Campos, T.F.C., Neiva, A.M.R., and Nardi, L.V.S., 2002, Geochemistry of the Rio Espinharas hybrid complex, northeastern Brazil: Lithos, v. 64, p. 131-153.

Canil, D., and Fedortchouk, Y., 2000, Clinopyroxene-liquid partitioning for vanadium and the oxygen fugacity during formation of cratonic and oceanic mantle lithosphere: Journal of Geophysical Research, v. 105, p. 26,003-26,016

Cao, M., Li, G., Qin, K., Seitmuratova, E.Y., and Liu, Y., 2012, Major and trace element characteristics of apatite in granitoids from central Kazakhstan: Implications for petrogenesis and mineralization: Resource Geology, v. 62 , p. $63-83$.

Cao, M., Qin, K., Li, G., Jin, L., Evans, N., and Yang, X., 2014, Baogutu: An example of a reduced porphyry $\mathrm{Cu}$ deposit in western Junggar: Ore Geology Reviews, v. 56, p. 159-180.

Casquet, C., Galindo, C., Tornos, F., Velasco, F., and Canales, A., 2001, The Aguablanca $\mathrm{Cu}-\mathrm{Ni}$ ore deposit (Extremadura, Spain), a case of synorogenic orthomagmatic mineralization: age and isotope composition of magmas ( $\mathrm{Sr}$, Nd) and ore (S): Ore Geology Reviews, v. 18, p. 237-250.

Cawood, P.A., and Hawkesworth, C.J., 2015, Temporal relations between mineral deposits and global tectonic cycles: Geological Society of London, Special Publications, v. 393, p. 9-12.

Chen, N., Pan, Y., and Weil, J.A., 2002, Electron paramagnetic resonance spectroscopic study of synthetic fluorapatite: Part I. Local structural environment and substitution mechanism of $\mathrm{Gd}$ at the $\mathrm{Ca} 2$ site: American Mineralogist, v. 87 , p. $37-46$

Christiansen, E.H., and Keith, J.D., 1996, Trace element systematics in silicic magmas: A metallogenic perspective, in Wyman, D.A., ed., Trace element geochemistry of volcanic rocks: Applications for massive sulphide exploration: Geological Association of Canada Short Course Notes 12, p. 115-151.

Chu, M.-F., Wang, K.-L., Griffin, W.L., Chuang, S.-L., O'Reilly, S.Y., Pearson, N.J., and Iizuka, Y., 2009, Apatite composition: Tracing petrogenetic processes in Transhimalayan granitoids: Journal of Petrology, v. 50, p. $1829-1855$
Colpron, M., and Nelson, J.L., 2011, A digital atlas of terranes for the northern Cordillera: Yukon Geological Survey, British Columbia Ministry of Energy and Mines, British Columbia Geological Survey GeoFile 2011-11, (http://www.geology.gov.yk.ca/bedrock_terrane.html).

Comodi, P., Liu, Y., Stoppa, F., and Woolley, A.R., 1999, A multi-method analysis of Si-, S- and REE-rich apatite from a new kind of kalsilite-bearing leucitite (Abruzzi, Italy): Mineralogical Magazine, v. 63, p. 661-672

Condie, K.C., and Kroner, A., 2008, When did plate tectonics begin? Evidence from the geologic record, in Condie, K.C., and Pease, V., eds., When did plate tectonics begin on planet Earth?: Geological Society of America Special Paper 440, p. 281-294.

Cooke, D.R., and Simmons, S.F., 2000, Characteristics and genesis of epithermal gold deposits: Reviews in Economic Geology, v. 13, p. 221-244.

Cornett, J., Chant, L., and Risto, B., 1992, Arsenic transport between water and sediments: Hydrobiologia, v. 235/236, p. 533-544.

Cullers, R.L., and Medaris Jr., D., 1977, Rare earth elements in carbonatite and cogenetic alkaline rocks: Examples from Seabrook Lake and Callander Bay, Ontario: Contributions to Mineralogy and Petrology, v. 65, p. 143-153.

De Maesschalck, R., Jouan-Rimbaud, D., and Massart, D.L., 2000, The Mahalanobis distance: Chemometrics and Intelligent Laboratory Systems, v. 50 , p. $1-18$.

Dilles, J.H., Kent, J.R., Wooden, J.L., Tosdal, R.M., Koleszar, A., Lee, R.G. and Farmer, L.P., 2014, Zircon compositional evidence for sulfur-degassing from ore-forming arc magmas: Economic Geology, v. 110, p. 1-11.

Dong, P., 2005, Halogen-element ( $\mathrm{F}, \mathrm{Cl}$, and $\mathrm{Br}$ ) behavior in apatite, scapolite, and sodalite: An experimental investigation with field applications Unpublished Ph.D. thesis, Saskatoon, Saskatchewan, University of Saskatchewan, $222 \mathrm{p}$

Dubé, B., and Gosselin, P., 2007, Greenstone-hosted quartz-carbonate vein deposits, in Goodfellow, W.D., eds., Mineral deposits of Canada: A synthesis of major deposit types, district metallogeny, the evolution of geological provinces, and exploration methods: Geological Association of Canada, Mineral Deposits Division Special Publication no. 5, p. 49-73.

Duuring, P., Rowins, S.M., McKinley, B.S., Dickinson, J.M., Diakow, L.J., Kim, Y.-S., and Creaser, R.A., 2009a, Examining potential links between Jurassic porphyry $\mathrm{Cu}-\mathrm{Au} \pm \mathrm{Mo}$ and epithermal $\mathrm{Au} \pm \mathrm{Ag}$ mineralization in the Toodoggone district of north-central British Columbia, Canada: Mineralium Deposita, v. 44, p. 463-496.

2009b, Magmatic and structural controls on porphyry-style $\mathrm{Cu}-\mathrm{Au}-\mathrm{Mo}$ mineralization at Kemess South, Toodoggone district of British Columbia, Canada: Mineralium Deposita, v. 44, p. 435-462.

Dybczynski, R., Polkowska-Motrenko, H., Samczynaski, Z., and Szopa, Z., 1991, Two new polish geological-environmental reference materials: Apatite concentrate (CTA-AC-1) and fine fly ash (CTA-FFA-1): Geostandards Newsletter, v. 15, p. 163-185.

Einaudi, M.T., Meinert, L.D., and Newberry, R.J., 1981, Skarn deposits: Economic Geology $75^{\text {th }}$ Anniversary Volume, p. 317-391.

Engel, G., Kreig, F., and Reif, G., 1975, Mischekristallbildung und kationeordnung im system bleihydroxylapatit-calciumhydroxylapatit: Journal of Solid State Chemistry, v. 15, p. 117-126.

Ercit, T.S., Cerny, P., Groat, L.A., 1994, The crystal structure of Mn-rich fluorapatite and the role of $\mathrm{Mn}$ in the apatite structure [abs.]: Geological Association of Canada-Mineralogical Association of Canada Abstract, v. 19, p. A34.

Ewart, A., and Griffin, W.L., 1994, Application of proton-microprobe data to trace-element partitioning in volcanic rocks: Chemical Geology, v. 117 p. 251-284.

Fleet, M.E., and Pan, Y., 1995, Site preference of rare earth elements in fluorapatite: American Mineralogist, v. 80, p. 329-335.

1997, Rare earth elements in apatite: Uptake from $\mathrm{H}_{2} \mathrm{O}$-bearing phosphate-fluoride melts and the role of volatile components: Geochimica et Cosmochimica Acta, v. 61, p. 4745-4760.

Fleet, M.E., Liu, X., and Pan, Y., 2000, Rare earth elements in chlorapatite $\left[\mathrm{Ca}_{10}\left(\mathrm{PO}_{4}\right)_{6} \mathrm{Cl}_{2}\right]$ : Uptake, site preference and degradation of monoclinic structure: American Mineralogist, v. 85, p. 1437-1446.

Flury, B., 1997, A first course in multivariate statistics: New York, SpringerVerlag, $715 \mathrm{p}$.

Goldfarb, R.J., Bradley, D., and Leach, D.L., 2010, Secular variation in economic geology: Economic Geology, v. 105, p. 459-465.

Goodfellow, W.D., ed., 2007, Mineral deposits of Canada: A synthesis of major deposit types, district metallogeny, the evolution of geological provinces, and exploration methods: Geological Association of Canada, Mineral Deposits Division, Special Publication no. 5, 1068 p. 
Griffin, W.L., and Ryan, C.G., 1995, Trace elements in indicator minerals: Area selection and target evaluation in diamond exploration: Journal of Geochemical Exploration, v. 53, p. 311-337.

Grimes, C.B., Cheadle, M.J., John, B.E., Reiners, P.W., and Wooden, J.L., 2011, Cooling rates and the depth of detachment faulting at oceanic core complexes: Evidence from zircon $\mathrm{Pb} / \mathrm{U}$ and $(\mathrm{U}-\mathrm{Th}$ )/He ages: Geochemistry, Geophysics, Geosystems, v. 12, no. 3, doi: 10.1029/2010GC003391.

Groves, D.I., 1993, The crustal continuum model for late Archean lode-gold deposits of the Yilgarn Block, Western Australia: Mineralium Deposita, v. 28, p. $366-374$

Groves, D.I., and Bierlein, F.P., 2007, Geodynamic settings of mineral deposit systems: Journal of the Geological Society of London, v. 164, p. 19-30.

Groves, D.I., Goldfarb, R.J., Gebre-Mariam, M., Hagemann, S.G., and Robert, F., 1998, Orogenic gold deposits: A proposed classification in the context of their crustal distribution and relationship to other gold deposit types: Ore Geology Reviews, v. 13, p. 7-27.

Groves, D.I., Condie, K.C., Goldfarb, R.J., Hronsky, J.M.A., and Veilreicher, R.M., 2005, Secular changes in global tectonic processes and their influence on the temporal distribution of gold-bearing mineral deposits: Economic Geology, v. 100, p. 203-224.

Groves, D.I., Bierlein, F.P., Meinert, L.D., and Hitzman, M.W. 2010, Iron oxide copper-gold (IOCG) deposits through Earth History: implications for origin, lithospheric setting, and distribution from other epigenetic iron oxide deposits: Economic Geology, v. 105, p. 641-654.

Guilbert, J.M., and Park, C.F., Jr., 1986, The geology of ore deposits: New York, W.H. Freeman and Company, $985 \mathrm{p}$

Hagemann, S.G., and Cassidy, K.F., 2000, Archean orogenic lode gold deposits: Reviews in Economic Geology, v. 13, p. 9-60.

Hammouda, T., Chantel, J., and Devidal, J.L., 2010, Apatite solubility in carbonatitic liquids and trace element partitioning between apatite and carbonatite at high pressure: Geochimica et Cosmochimica Acta, v. 74, p. 7220-7235.

Harrop, J.C., and Sinclair, A.J., 1986, A re-evaluation of production data Bridge River-Bralorne camp (92J): British Columbia Ministry of Energy, Mines and Petroleum Resources, British Columbia Geological Survey Paper 1986-1, Geological Fieldwork 1985, p. 303-310.

Hedenquist, J.W., Arribas, A.R., and Gonzalez-Urien, E., 2000, Exploration for epithermal gold deposits: Reviews in Economic Geology, v. 13, p. $245-277$.

Hitzman, M.W., Oreskes, N, and Einaudi, M.T., 1992, Geological characteristics and tectonic setting of Proterozoic iron oxide (Cu-U-Au-REE) deposits: Precambrian Research, v. 58, p. 241-287.

Hogarth, D.D., Hartree, R., Loop, J., and Solberg, T.N., 1985, Rare-earth element minerals in four carbonatites near Gatineau, Quebec: American Mineralogist, v. 70, p. 1135-1142.

Hughes, J.M., and Drexler, J.W., 1991, Cation substitution in the apatite tetrahedral site: crystal structures of type hydroxylellstadite and type fermorite: Neues Jahrbuch für Mineralogie-Monatshefte, p. 327-336.

Hughes, J.M., and Rakovan, J., 2002, The crystal structure of apatite, $\mathrm{Ca}_{5}\left(\mathrm{PO}_{4}\right)_{3}(\mathrm{~F}, \mathrm{OH}, \mathrm{Cl})$ : Reviews in Mineralogy and Geochemistry, v. 48, p. 1-12.

Hughes, J.M., Cameron, M., and Crowley, K.D., 1991, Ordering of divalent cations in apatite structure: Crystal structure refinements of natural Mnand Sr-bearing apatite: American Mineralogist, v. 76, p. 1857-1862.

Hughes, J.M., Ertl, A., Bernhardt, H.-J., Rossman, G.R., and Rakovan, J., 2004, Mn-rich fluorapatite from Austria: Crystal structure, chemical analysis, and spectroscopic investigations: American Mineralogist, v. 89, p. 629-632.

Hunt, J.A., Baker, T., Cleverley, J., Davidson, G.J., Fallick, A.E., and Thorkelson, D.J., 2011, Fluid inclusion and stable isotope constraints on the origin of Wernecke Breccia and associated iron-oxide-copper-gold mineralization, Yukon: Canadian Journal of Earth Sciences, v. 48, p. 1425-1445.

Ispolatov, V., Lafrance, B., Dube, B., Creaser, R., and Hamilton, M., 2008, Geologic and structural setting of gold mineralization in the Kirkland LakeLarder Lake gold belt, Ontario: Economic Geology, v. 103, p. 1309-1340.

Ito, J., 1968, Silicate apatite and oxyapatite: American Mineralogist, v. 53, p. 890-907.

Jochum, K.P., Weis, U., Stoll, B., Kuzmin, D., Yang, Q., Raczek, I., Jacob, D.E., Stracke, A., Birbaum, K., Frick, D.A., Günther, D., and Enzweiler, J., 2011, Determination of Reference Values for NIST SRM 610-617 Glasses Following ISO Guidelines: Geostandards and Geoanalytical Research, v. 35 , p. $397-429$.

Jones, A.P., Genge, M., and Carmody, L., 2013, Carbonate melts and carbonatites: Reviews in Mineralogy and Geochemistry, v. 75, p. 289-322.
Kerrich, R., and Polat, A., 2006, Archean greenstone-tonalite duality: thermochemical mantle convection models or plate tectonics in the early Earth global dynamics?: Tectonophysics, v. 415, p. 141-165.

Kerrich, R., Goldfarb, R., Groves, D.I., and Garwin, S., 2000, The geodynamics of world-class gold deposits: Characteristics, space-time distribution and origins: Reviews in Economic Geology, v. 13, p. 501-544.

Kerrich, R., Goldfarb, R.J., and Richards, J.P., 2005, Metallogenic provinces in an evolving dynamic framework: Economic Geology 100 th Anniversary Volume, p. 1097-1136.

Khudolozhkin, V.O., Urusov, V.S., Tobelko, K.I., 1973, Distribution of cations between sites in the structure of $\mathrm{Ca}, \mathrm{Sr}, \mathrm{Ba}$-apatite: Geochemistry International, v. 10, p. 266-269.

Khudolozhkin, V.O., Urusov, V.S., and Kurash, V.V., 1974, Mössbauer study of the ordering of $\mathrm{Fe}^{2+}$ in the fluor-apatite structure: Geochemistry International, v. 11, p. 748-750

Kingsley, J.D., Prener, J.S., and Segall, B., 1965, Spectroscopy of $\left(\mathrm{MnO}_{4}\right)^{3-}$ in calcium halophosphates: Physical Review, v. A137, p. 189-202.

Klemme, S. and Dalpé, C., 2003, Trace-element partitioning between apatite and carbonatite melt: American Mineralogist, v. 88, p. 639-646.

Knipping, J.L., Bilenker, L.D., Simon, A.C., Reich, M., Barra, F., Deditius, A.P., Lundstrom, C., Bindeman, I., and Munizaga, R., 2015a, Giant Kirunatype deposits form by efficient flotation of magmatic magnetite suspensions: Geology, v. 43, p. 591-594.

Knipping, J.L., Bilenker, L.D., Simon, A.C., Reich, M., Barra, F., Deditius, A.P., Walle, M., Heinrich, C.A., Holtz, F., and Munizaga, R., 2015b, Trace elements in magnetite from massive iron oxide-apatite deposits indicate a combined formation by igneous and magmatic-hydrothermal processes: Geochimica et Cosmochimica Acta, v. 171, p. 15-38.

Kutoglu, A., von, 1974, Structure refinement of the apatite $\mathrm{Ca}_{5}\left(\mathrm{VO}_{4}\right)_{3}(\mathrm{OH})$ Neues Jahrbuch für Mineralogie-Monatshefte, p. 210-218.

Lang, J.R., Stanley, C.R., and Thompson, J.F.H., 1995, Porphyry copper-gold deposits related to alkalic igneous rocks in the Triassic-Jurassic arc terranes of British Columbia, in Pierce, F.W., and Bolm, J.G., eds., Porphyry deposits of the American Cordillera: Arizona Geological Society Digest 20, p. 219-236.

Leeman, W.P., and Phelps, D.W., 1981, Partitioning of rare earths and other trace elements between sanidine and coexisting volcanic glass: Journal of Geophysical Research: Solid Earth, v. 86, p. 10,193-10,199.

Leitch, C.H.B., Dawson, K.M., and Godwin, C.I., 1989, Early late Cretaceous-early Tertiary gold mineralization: A galena lead isotope study of the Bridge River Mining Camp, southwestern British Columbia, Canada: Economic Geology, v. 84, p. 2226-2236.

Lodders, K, 2010, Solar system abundances of the elements, in Goswami, A., and Reddy, B.E., eds., Principles and perspectives in cosmochemistry: Kodai School on Synthesis of Elements in Stars, Kodaikanal Observatory, India, April 29-May 13, 2008, Berlin, Heidelberg, Springer Verlag, Lecture Notes, p. 379-417.

Lollar, B.S., 2004, Environmental Geochemistry: Oxford, UK, Elsevier, Treatise on Geochemistry, Volume 9, p. 26-35.

Loucks, R.R., 2014, Distinctive composition of copper-ore-forming arc magmas: Australian Journal of Earth Sciences, v. 61, p. 5-16.

Luhr, J.F., and Carmichael, I.S.E., 1980, The Colima volcanic complex, Mexico: I. Post-caldera andesites from Volcán Colima: Contribution to Mineralogy and Petrology, v. 71, p. 343-372.

Lydon, J.W., 2007, An overview of the economic and geological contexts of Canada's major mineral deposit types, in Goodfellow, W.D., eds., Mineral deposits of Canada: a synthesis of major deposit types, district metallogeny, the evolution of geological provinces, and exploration methods: Geological Association of Canada, Mineral Deposits Division Special Publication no. 5 , p. $3-48$.

Lyons, J.I., 1988, Volcanogenic iron oxide deposits, Cerro de Mercado and vicinity, Durango, Mexico: Economic Geology, v. 83, p. 1886-1906.

Mahalanobis, P.C., 1936, On the generalized distance in statistics: Proceedings of the National Institute of Science of India, v. 12, p. 49-55.

Mahood, G., and Hildreth, W., 1983, Large partition coefficients for trace elements in high-silica rhyolites: Geochimica et Cosmochimica Acta, v. 47, p. $11-30$

Manor, M.J., Scoates, J., Nixon, G.T., and Ames, D.E., 2016, The giant Mascot Ni-Cu-PGE deposit, British Columbia: Mineralized conduits in a convergent margin tectonic setting: Economic Geology, v. 111, p. 57-87.

Mao, J., Yu, J., Yuan, S., Chen, Y., Xie, G., Hou, K., Xiang, J., and Yang, Z., 2008 , Iron oxide-copper-gold deposits: Characteristics, present research situation and ore prospecting: Mineral Deposits, v. 27, p. 267-278. (in Chinese). 
McMillian, W.J., 1976, Geology and genesis of the Highland Valley ore deposits and the Guichon Creek batholith: Canadian Institute of Mining and Metallurgy, Special Volume 15, p. 85-104.

Meinert, L.A., Dipple, G.M., and Nicolescu, S., 2005, World skarn deposits: Economic Geology $100^{\text {th }}$ Anniversary Volume, p. 299-336.

Michael, P.J., 1988, Partition coefficients for rare earth elements in mafic minerals of high silica rhyolites: The importance of accessory mineral inclusions: Geochimica et Cosmochimica Acta, v. 52, p. 275-282.

Miles, A.J., Graham, C.M., Hawkesworth, C.J., Gillespie, M.R., Hinton, R.W., Bromiley, G.D., and EMMAC, 2014, Apatite: A new redox proxy for silicic magmas? Geochimica et Cosmochimica Acta, v. 132, p. 101-119.

Mukhopadhyay, S., Ray, J., Balaram, V., Krishna, A.K., and Ghosh, B., 2011, Geochemistry and petrogenesis of syenites and associated rocks of the Elagiri complex, southern Granulite Terrane, India: Journal of Asian Earth Sciences, v. 42 , p. $1256-1270$

Mumin, A.H., Corriveau, L., Somarin, A.K., and Ootes, L., 2007, Iron oxide copper-gold-type polymetallic mineralization in the Contact Lake belt, Great Bear magmatic zone, Northwest Territories, Canada: Exploration and Mining Geology, v. 16, p. 187-208.

Naldrett, A.J., 2004, Magmatic sulfide deposits: geology, geochemistry and exploration: Berlin, Springer-Verlag, $727 \mathrm{p}$.

Nash, W.P., 1984, Phosphate minerals in terrestrial igneous and metamorphic rocks, in Nriagu, J.O. and Moore, P.B., eds., Phosphate minerals: SpringerVerlag, p. 215-241.

Nelson, D.R., Chivas, A.R., Chappell, B.W., and McCulloch, M.T., 1988, Geochemical and isotopic systematics in carbonatites and implications for the evolution of ocean-island sources: Geochimica et Cosmochimica Acta, v. 52 , p. $1-17$.

Newberry, R.J., 1998, W- and Sn-skarn deposits: A status report, in Lentz, D.R., ed., Mineralized intrusion-related skarn systems: Mineralogical Association of Canada Short Course 26, p. 289-336.

Olade, M.A., and Fletcher, W.K., 1976, Trace element geochemistry of the Highland Valley and Guichon Creek Batholith in relation to porphyry copper mineralization: Economic Geology, v. 71, p. 733-748.

Oliver, N.H.S., Cleverley, J.S., Mark, G., Pollard, P.J., Rubenach, M.J., Marshall, L.J., Williams, P.J., and Baker, T., 2004, Geochemistry and geochemical modeling of fluid-rock interaction in the eastern Mt Isa block, Australia: The role of sodic alteration in the genesis of iron oxide copper-gold deposits: Economic Geology, v. 99, p. 1145-1176.

Ortega, L., Lunar, R., García-Palomero, F., Moreno, T., Martín Estévez, J.R., Prichard, H.M., and Fisher, P.C., 2004, The Aguablanca Ni-Cu-PGE deposit, southwestern Iberia: Magmatic ore-forming processes and retrograde evolution: Canadian Mineralogist, v. 42, p. 325-335.

O'Reilly, S.Y., and Griffin, W.L., 2000, Apatite in the mantle: Implications for metasomatic processes and high heat production in Phanerozoic mantle: Lithos, v. 53, p. 217-232.

Pan, Y., and Fleet, M.E., 2002, Compositions of the apatite-group minerals: Substitution mechanisms and controlling factors: Reviews in Mineralogy and Geochemistry, v. 48, p. 13-49.

Parsapoor, A., Khalili, M., and Mackizadeh, M.A., 2009, The behaviour of trace and rare earth elements (REE) during hydrothermal alteration in the Rangan area (central Iran): Journal of Asian Earth Sciences, v. 34, p. 123-134.

Paster, T.P., Schauwecker, D.S., and Haskin, L.A., 1974, The behaviour of some trace elements during solidification of the Skaergaard layered series: Geochimica et Cosmochimica Acta, v. 38, p. 1549-1577.

Peng, G.Y., Juhr, J.F., and McGee, J.J., 1997, Factors controlling sulfur concentrations in volcanic apatite: American Mineralogist, v. 82, p. 1210-1224.

Persiel, E.-A., Blanc, P., and Ohnenstetter, D., 2000, As-bearing fluorapatite in manganiferous deposits from St. Marcel-Praborna, Val d'Aosta, Italy: Canadian Mineralogist, v. 38, p. 101-117.

Piccoli, P.M., and Candela, P.A., 2002, Apatite in igneous systems: Reviews in Mineralogy and Geochemistry, v. 48, p. 255-292.

Pina, R., Lunar, R., Ortega, L., Gervilla, F., Alapieti, T., and Martinez, C., 2006, Petrology and geochemistry of mafic-ultramafic fragments from the Aguablanca Ni-Cu ore breccia, southwest Spain: Economic Geology, v. 101, p. $865-881$.

Prowatke, S., and Klemme, S., 2006, Trace element partitioning between apatite and silicate melts: Geochimica et Cosmochimica Acta, v. 70, p. $4513-4527$.

Pouchou, J.L. and Pichoir, F., 1985, "PAP" $\Phi(\rho \mathrm{Z})$ procedure for improved quantitative microanalysis: Microbeam Analysis 1985, 20th, Annual Conference of the Microbeam Analysis Society, Louisville, Kentucky, August 5-9, 1985, San Francisco Press Inc., Proceedings, p. 104-106.
Rakovan, J., 2007, Nelsonite and Kiruna-type deposits: Rocks and Minerals, v. 82 , p. $249-251$.

Rakovan, J., and Hughes, J.M., 2000, Strontium in the apatite structure: Strontium fluorapatite and belovite-(Ce): Canadian Mineralogist, v. 38 p. 839-845.

Rankin, A.H., 2005, Carbonatite-associated rare metal deposits: Composition and evolution of ore-forming fluids - the fluid inclusion evidence, in Linnen, R.L., and Samson, I.M., eds., Rare-element geochemistry and mineral deposits: Geological Association of Canada Short Course Notes 17, p. 299-314.

Ray, G.E., 1998, Au skarns: British Columbia Ministry of Employment and Investment, British Columbia Geological Survey Paper 1998-1, Geological Fieldwork 1997, p. 24H-1-24H-4.

2013, Skarns of the Canadian Cordillera: British Columbia Ministry of Energy and Mines, British Columbia Geological Survey Paper 2013-11, $112 \mathrm{p}$.

Richards, J.P., 1990, Petrology and geochemistry of alkalic intrusives at the Porgera gold deposit, Papua New Guinea: Journal of Geochemical Exploration, v. 35, p. 141-199.

Richards, J.R., and Mumin, H., 2014, Porphyry Cu and IOCG: Geology, v. 55 , p. 302-304.

Robert, F., 2001, Syenite-associated disseminated gold deposits in the Abitibi greenstone belt, Canada: Mineralium Deposita, v. 36, p. 503-516.

Roeder, P.L., MacArthur, D., Ma, X.P., and Palmer, G.R., 1987, Cathodoluminescence and microprobe study of rare-earth elements in apatite: American Mineralogist, v. 72, p. 801-811.

Rouse, R.C., and Dunn, P.J., 1982, A contribution to the crystal chemistry of ellestadite and the silicate sulfate apatite: American Mineralogist, v. 67 , p. 90-96.

Rowins, S.M., 2000, Reduced porphyry $\mathrm{Cu}-\mathrm{Au}$ deposits: A new variation on an old theme: Geology, v. 28, p. 491-494.

Rowins, S.M., Lalonde, A.E., and Cameron, E.M., 1991, Magmatic oxidation in the syenitic Murdock Creek intrusion, Kirkland Lake, Ontario: Evidence from the ferromagnesian silicates: Journal of Geology, v. 99, p. 395-414.

Rowins, S.M., Cameron, E.M., Lalonde, A.E., and Ernst, R.E., 1993, Petrogenesis of the late Archean syenitic Murdock Creek pluton, Kirkland Lake, Ontario: Evidence for an extensional tectonic setting: Canadian Mineralogist, v. 31, p. 219-244.

Rønsbo, J.G., 1989, Coupled substitution involving REEs and Na and Si in apatite in alkaline rocks from the Illimaussaq intrusions, South Greenland, and the petrological implications: American Mineralogist, v. 74, p. 896-901.

Ryan, F.M., Hopkins, R.H., Warren, R.W., 1972, The optical properties of divalent manganese in strontium fluorophosphate: A comparison with calcium fluorophosphates: Journal of Luminescence, v. 5, p. 313-333.

Sappin, A.-A., Constantin, M., and Clark, T., 2011, Origin of magmatic sulfides in a Proterozoic island arc - an example from the Portneuf-Mauricie Domain, Grenville province, Canada: Mineralium Deposita, v. 46, p. 211-237.

2012, Petrology of mafic and ultramafic intrusions from the PortneufMauricie Domain, Grenville province, Canada: Implications for plutonic complexes in a Proterozoic island arc: Lithos, v. 154, p. 277-295.

Scales, M., 1989, Niobec: one-of-a-kind mine: Canadian Mining Journal, v. 110 , p. $43-46$.

Schroeter, T.G., 1987, Brief studies of selected gold deposits in southern British Columbia: British Columbia Ministry of Energy and Mines, British Columbia Geological Survey Paper 1987-1, Geological Fieldwork 1986, p. 15-22.

Schultz, D.J., 1996, The fluid history of the Seabee mesothermal gold deposit northern Saskatchewan: Unpublished M.Sc. thesis, Saskatoon, Saskatchewan, University of Saskatchewan, $122 \mathrm{p}$

Seedorff, E., Dilles, J.H., Proffett, J.M. Jr., Einaudi, M.T., Zurcher, L., and Stavast, W.J.A., 2005, Porphyry deposits: Characteristics and origin of hypogene features: Economic Geology 100th Anniversary Volume, p. 251-298.

Serret, A., Cabañas, M.V., and Vallet-Regí, M., 2000, Stabilization of calcium oxyapatite with lanthanum(III)-created anionic vacancies: Chemistry of Materials, v. 12 , p. 3836-3841.

Sha, L.-K., and Chappell, B.W., 1999, Apatite chemical composition, determined by electron microprobe and laser-ablation inductively coupled plasma mass spectrometry, as a probe into granite petrogenesis: Geochimica et Cosmochimica Acta, v. 63, p. 3861-3881.

Shannon, R.D., 1976, Revised effective ionic radii and systematic studies of interatomic distances in halides and chaleogenides: Acta Crystallographica, v. A32, p. $751-767$. 
Sillitoe, R.H., 2003, Iron oxide-copper-gold deposits: an Andean view: Mineralium Deposita, v. 38, p. 787-812.

-2010, Porphyry copper systems: Economic Geology, v. 105, p. 3-41.

Simmons, S.F., White, N.C., and John, D.A., 2005, Geological characteristics of epithermal precious and base metal deposits: Economic Geology $100^{\text {th }}$ Anniversary Volume, p. 485-522.

Simonetti, A., Buzon, M.R., and Creaser, R. A., 2008, In-situ elemental and $\mathrm{Sr}$ isotope investigation of human tooth enamel by laser ablation-(MC)ICP-MS: Successes and pitfalls: Archaeometry, v. 50, p. 371-385.

Smith, C.M., Canil, D., Rowins, S.M., and Friedman, R.M., 2012, Reduced granitic magmas in an arc setting: The Catface porphyry $\mathrm{Cu}-\mathrm{Mo}$ deposit of the Paleogene Cascade Arc: Lithos, v. 154, p. 361-373.

Streck, M.J. and Dilles, J.H., 1998, Sulfur evolution of oxidized arc magmas as recorded in apatite from a porphyry copper batholith: Geology, v. 26, p. 523-526.

Sudarsanan, K., and Young, R.A., 1974, Structure refinement and random error analysis for strontium 'chlorapatite,' $\mathrm{Sr}_{5}\left(\mathrm{PO}_{4}\right)_{3} \mathrm{Cl}$ : Acta Crystallographica, v. B30, p. 1381-1386.

Sudarsanan, K., Young, R.A., and Wilson, A.J.C., 1977, The structures of some cadmium "apatite" $\mathrm{Cd}_{5}\left(\mathrm{MO}_{4}\right)_{3} \mathrm{X}$ : I. Determination of the structures of $\mathrm{Cd}_{5}\left(\mathrm{VO}_{4}\right)_{3} \mathrm{I}, \mathrm{Cd}_{5}\left(\mathrm{PO}_{4}\right)_{3} \mathrm{Br}, \mathrm{Cd}_{5}\left(\mathrm{AsO}_{4}\right)_{3} \mathrm{Br}$ and $\mathrm{Cd}_{5}\left(\mathrm{VO}_{4}\right)_{3} \mathrm{Br}$ : Acta Crystallographica, v. B33, p. 3136-3142.

Thomson, S.N., Gehrels, G.E., Ruiz, J., and Buchwaldt, R., 2012, Routine low-damage apatite U-Pb dating using laser ablation-multicollector-ICPMS: Geochemistry, Geophysics, Geosystems, v. 13, doi: 10.1029/2011GC003928.

Tollari, N., Barnes, S.-J., Cox, R.A., and Nabil, H., 2008, Trace element concentrations in apatite from the Sept-Îles intrusive suite, Canada-implications for the genesis of nelsonites: Chemical Geology, v. 252, p. 180-190.

Toplis, M. and Corgne, A., 2002, An experimental study of element partitioning between magnetite, clinopyroxene and iron-bearing silicate liquids with particular emphasis on vanadium: Contributions to Mineralogy and Petrology, v. 144, p. 22-37.

Tourigny, G., 2003, Preliminary structural study of the gold-bearing shear zone system at the Seabee mine, northern Saskatchewan: Saskatchewan Geological Survey, Summary of Investigations 2003, v. 2, p. B1-11.

Verbeeck, R.M.H., Lassuyt, C.J., Heijligers, H.J.M., Driessens, F.C.M., and Vrolijk, J.W.G.A., 1981, Lattice parameters and cation distribution of solid solutions of calcium and lead hydroxyapatite: Calcified Tissue International, v. 33 , p. $243-247$.
Wang, L.-X., Marks, M.A.W., Wenzel, T., Von Der Handt, A., Keller, J. Teiber, H., and Markl, G., 2014, Apatite from the Kaiserstuhl volcanic complex, Germany: New constraints on the relationship between carbonatite and associated silicate rocks: European Journal of Mineralogy, v. 26, p. 397-414.

Wang, Y., Fan, W., and Guo F., 2003, Geochemistry of early Mesozoic potassium-rich diorites-granodiorites in southeastern Hunan Province, South China: Petrogenesis and tectonic implications: Geochemical Journal, v. 37, p. 427-448.

Ward, B., Maynard, D., Geertsema, M. and Rabb, T., 2009, Iceflow history, drift thickness and drift prospecting for a portion of the QUEST Project area, central British Columbia (NTS 093G, H [west half], J): Geoscience BC, Summary of Activities 2008, Geoscience BC, Report 2009-1, p. 25-32. Warren, R.W., and Mazelsky, R., 1974, EPR of $\mathrm{Mn}^{2+}$ in calcium fluorophosphate. II. Modified Ca(II) site: Physical Review, v. B10, p. 19-25.

Watson, E.B., 1980, Apatite and phosphorus in mantle source regions: An experimental study of apatite/melt equilibria at pressures to $25 \mathrm{kbar}$ : Earth and Planetary Science Letters, v. 51, p. 322-335.

Watson, E.B., and Green, T.H., 1981, Apatite/liquid partition coefficients for the rare earth elements and strontium: Earth and Planetary Science Letters, v. 56 , p. $405-421$.

Wong, R.H., and Spence, C.D., 1995, Copper-gold mineralization in the Willa breccia pipe, southeastern British Columbia, in Schroeter, T.G., ed., Porphyry deposits of the Northwestern Cordillera of North America, Canadian Institute of Mining and Metallurgy Special Volume 46, p. 401-409.

Woolley, A.R., and Kemp, P.R.C., 1989, Carbonatites: Nomenclature, average chemical composition and element distribution, in Bell, K., ed., Carbonatites: Genesis and evolution: London, Unwin Hyman, p. 1-14.

Woolley, A.R., and Kjarsgaard, B.A., 2008, Carbonatite occurrences of the world: Map and database: Geological Survey of Canada, Open File 5796, $28 \mathrm{p}$.

Young, E.J., Myers, A.T., Munson, E.L., and Conklin, N.M., 1969, Mineralogy and geochemistry of fluorapatite from Cerro de Mercado, Durango, Mexico: U.S. Geological Survey Paper, v. 650D, p. 84-93.

Zirner, A.L.K., Marks, M.A.W., Wenzel, T., Jacob, D.E., and Markl, G., 2015, Rare earth elements in apatite as a monitor of magmatic and metasomatic processes: The Ilimaussaq complex, South Greenland: Lithos, v. 228-229, p. 12-22. 